\title{
Solar stills: A comprehensive review of designs, performance and material advances
}

\author{
Dsilva Winfred Rufus $D^{1}$, S. Iniyan ${ }^{1}$, L. Suganthi ${ }^{2}$ and P. A. Davies ${ }^{* 3}$ \\ 1-Institute for Energy Studies, Anna University, Chennai-600025, India \\ 2-Anna University, Chennai-600025, India \\ 3-Sustainable Environment Research Group, Engineering and Applied Science, Aston \\ University, Birmingham, UK, B4 7ET \\ * Corresponding author: p.a.davies@aston.ac.uk
}

\begin{abstract}
The demand for fresh water production is growing day by day with the increase in world population and with industrial growth. Use of desalination technology is increasing to meet this demand. Among desalination technologies, solar stills require low maintenance and are readily affordable; however their productivity is limited. This paper aims to give a detailed review about the various types of solar stills, covering passive and active designs, single- and multi-effect types, and the various modifications for improved productivity including reflectors, heat storage, fins, collectors, condensers, and mechanisms for enhancing heat and mass transfer. Photovoltaic-thermal and greenhouse type solar stills are also covered. Material advances in the area of phase change materials and nanocomposites are very promising to enhance further performance; future research should be carried out in these and other areas for the greater uptake of solar still technology.
\end{abstract}

Keywords: Solar still, desalination, performance, phase change materials, nanocomposites

\section{Table of contents}

1. Introduction

2. General parameters affecting the performance of solar stills

2.1 Climatic conditions

2.2 Water depth

3. Passive solar stills

3.1 Basic single-effect solar still

3.2 Solar reflectors

3.3 Wicked and stepped-basin solar still

$3.4 \quad$ Fins

3.5 Heat storage

3.5.1 Sensible heat storage

3.5.2 Latent heat storage

3.6 Unconventional shapes 
3.6.1 Triangular stills

3.6.2 Tubular stills

3.6.3 Hemispherical stills

3.6.4 Multi-slopes

3.6.5 Vertical stills

3.7 Multiple-effect passive solar still

3.7.1 Multi-wick solar stills

3.7.2 Multi-basin solar stills

4. Active solar stills

$4.1 \quad$ Solar collector

4.1.1 Flat plate collector

4.1.2 Evacuated tube collector

4.1.3 Solar ponds

4.1.4 Concentrating collector

4.1.5 Air heater

4.2 Enhanced condensers

4.2.1 Internal condenser

4.2.2 External condenser

4.2.3 Regenerators

4.3 Enhanced heat and mass transfer

4.3.1 Rotating shaft

4.3.2 Chimney and cooling tower

4.3.3 Vibratory harmonic effect

4.4 Photovoltaic-thermal stills

4.5 Multiple-effect active stills

5. Greenhouse type solar stills

6. Future material advancement

7. Economic analysis of solar stills

8. Conclusions

9. $\quad$ Scope for future work

Acknowledgements

References

\section{Introduction}

Water scarcity is a major global challenge. By the year 2025, it is estimated that $1 / 4$ of world population will be affected by water scarcity, and $2 / 3$ will experience water-stressed conditions. By 2030, 1/2 of world population will experience high water stress [1]. Presently, African regions are experiencing high water stress affecting up to $31 \%$ of the population, followed by Asia, America and Europe with $25 \%, 7 \%$ and $2 \%$ of high water stress respectively [2-5]. Desalination has a growing role to play in meeting the demands for fresh water. 
There are various methods of desalinating sea and brackish water. These include flash distillation, multi-effect distillation, membrane distillation, reverse osmosis, forward osmosis, ion exchange, capacitive deionisation, electrodialysis and seawater greenhouse technology [6, 7]. The energy for desalination can be obtained from fossil fuel or alternate energy sources such as biomass, wind, solar, geothermal energy, or industrial waste heat. Among the various methods of solar desalination, solar stills have several advantages including simplicity, low cost, ease of maintenance, and low environmental impact. However, they also have disadvantages, such as low performance, that hinder their commercial uptake.

Generally, solar still works on evaporation and condensation process. The brine inside the solar still is evaporated using solar energy and the condensate is collected as the distilled water output. In a double- or multiple-effect solar still, this process is repeated such that the heat of condensation is used to drive a subsequent evaporation process. Use of multiple effects tends to increase the performance but with a cost penalty associated. Use of active components, such as pumps and fans, is another way to boost performance, but also introduces penalties with regard to cost and complexity.

The performance of a solar still may be quantified by efficiency and productivity. For a single-effect still, efficiency is defined as the ratio of latent heat energy of the condensed water to the total amount of solar energy incident on the still. Instantaneous efficiency specifies the efficiency over a short period (typically 15 minutes) whereas overall efficiency specifies for the whole day. Productivity is the water output per area of solar still per day. The productivity for a basic passive solar still is only about $2-5 \mathrm{~L} / \mathrm{m}^{2}$.day; thus at least $1 \mathrm{~m}^{2}$ of area is required to supply the essential needs of one person [8]. This review focuses on the existing and emerging techniques to improve the performance of solar stills.

Many reviews of solar stills have been written, especially with respect to design and development [9-12], performance enhancement [13-17], wick type [18] and modelling [19]. Nonetheless, recent advances including new materials (such as phase change materials and nano-composites) promise significant improvements in performance, thus introducing the need for a fresh review. Here we present an up-to-date and comprehensive review of the state of the art in solar stills. An overview of the studies covered by this review is given in Table 1 .

Both efficiency and productivity depend on many operating and design parameters which are discussed in this review. Some general parameters such as climate and water depth affect both passive and active solar stills in comparable ways, and are therefore discussed under common headings in section 2 below. Then in sections 3 and 4 we discuss separately parameters affecting the performances of passive and active stills respectively. In section 5 , we discuss greenhouse-type solar stills (which may be of both passive and active type) and in section 6 we outline the trends in emerging materials that are likely to affect solar still development in coming years. Section 7 covers economic aspects. Finally, sections 8 and 9 contain the conclusions and recommendations for future work. 


\section{General parameters affecting the performance of solar stills}

\section{$2.1 \quad$ Climatic conditions}

Solar radiation intensity is the main climatic parameter affecting productivity. At constant efficiency, daily productivity will be proportional to solar irradiation $\left(\mathrm{kJ} / \mathrm{m}^{2}\right.$.day). However, wind speed and ambient temperature also affect performance. An experimental study by Sebaii (2004) showed that the productivity of a solar still increases with wind speed only below the critical speed of $4.5 \mathrm{~m} / \mathrm{s}$ [20,21]. Tiwari et al. (2014) modelled the effects of various climatic conditions in active and passive distillation systems, and found that wind increased performance up to this same critical speed of $4.5 \mathrm{~m} / \mathrm{s}$ beyond which the productivity remained constant [21]. This is because wind enhances heat transfer from the cover and thus condensation up to the critical speed, beyond which there is little further enhancement $[22,23]$.

\section{$2.2 \quad$ Water depth}

Water depth affects the efficiency of solar stills with respect to the duration of operation in the following manner. For short durations (less than two days) smaller depth generally increases efficiency. Over longer durations, more depth may be required to prevent the still from drying out [24]. Singh et al. (2004) carried out a performance study under Indian climatic conditions on active and passive still and inferred that water depth, together with inclination of condensing cover and collector, have a strong effect on the annual yield [25]. Rajesh et al. (2006) compared various depths such as $0.05 \mathrm{~m}, 0.1 \mathrm{~m}$ and $0.15 \mathrm{~m}$ for both active and passive stills and concluded that productivity was maximised at $0.1 \mathrm{~m}$. The decrease at large depths may occur because it takes more time to warm up the larger volume of water [26].

\section{Passive solar stills}

A passive solar still is one in which evaporation and condensation processes take place naturally. There are many ways to classify passive solar stills according, for example, to evaporator design and materials (e.g. wicks), heat storage options, shapes and number of basins. Use of multiple basins or wicks can provide multiple-effect distillation for much higher output. Here we review first the basic solar still, before reviewing the various options to enhance its performance.

\subsection{Basic single-effect solar still}

The single-slope, single-basin solar still (fig 1) can be considered as the basic type of passive still against which more advanced designs should be compared. Many studies have been done on it, with variations in parameters like the type of the material used, the inclination angle of glass cover and cooling, absorbing material inside the solar still, composition of feed water and type of basin liner [27-39].

The choice of material influences performance, as demonstrated by Panchal (2011), who conducted experiments using various solar stills including aluminium and galvanised iron types. It was found that higher distillate output of around $3.8 \mathrm{~L} / \mathrm{m}^{2}$.day was achieved by the 
aluminium solar still compared to only $2.6 \mathrm{~L} / \mathrm{m}^{2}$.day the galvanised iron type; this difference was attributed to increased thermal conductivity of the aluminium [27].

The inclination angle of the glass affects parameters such as yield rate and instantaneous efficiency. Different researchers, however, reached different conclusions about the optimal inclination. Tiwari et al. (2009) modelled a passive solar still with respect to inclination angle for the condensing cover and concluded that the optimum angle is $15^{\circ}$ in Delhi (latitude $28.6^{\circ}$ ) [28]. Muhammed et al. (2007) designed a single basin solar still for south western arid region of Pakistan (latitude $33.7^{\circ}$ North) and recommended that the optimum glass cover angle was $33.3^{\circ}$ [29]. Rahul Dev et al. (2009) also conducted experiments in Delhi (latitude $28.6^{\circ}$ North) with various inclination angles and validated the experimental observations against model equations. They found that the inclination angle of $45^{\circ}$ maximises instantaneous efficiency [30]. Though it can be suggested that the inclination angle should equal the latitude angle, this is not consistently the case among the theoretical and experimental studies reported.

The instantaneous efficiency increases with the temperature of the feed water [31]. Medugu (2009) carried out a study on instantaneous efficiency with respect to radiation and feed water temperature and verified the experimental values against theoretical predictions by calculating energy balance equations for every component of the solar still [31,32]. Zurigat (2010) analysed the performance of a single-basin solar still with double glass cover, with preheating of the brine and cooling of the cover. It was found that there was an improvement in performance due to increase in the evaporation rate with efficiency increased up to $25 \%$ [33]. Aboul (1998) obtained an even higher increase of $27 \%$ also with brine preheating (fig 30) [34].

The composition of feed water used also affects the total productivity of the still. Vinoth Kumar (2008) carried out an experimental study using various feeds such as tap water, seawater and dairy industrial effluent and observed that the productivity was greater for both seawater and tap water than for the effluent. This difference was attributed to the suspended solid particles in the industrial effluent [35].

The productivity of single-basin stills also varies with the type of basin liner used. Badran (2007) conducted experiments with two types of liner (black paint and asphalt) and found that the use of asphalt in the basin increased the output by about $29 \%$ [36].

A number of researchers have characterised heat capacity and heat transfer coefficients in solar stills. Rabbar (2013) found that the ratio of evaporative over convective heat transfer was a function of glass and water temperature [37]. Narjes et al. (2011) simulated the heat transfer coefficient for solar desalination still using computer fluid dynamics; it was inferred that the rate of fresh water production does not change significantly with radiation heat transfer coefficients but it was influenced by the temperature of water and glass cover [38]. Sivakumar et al. (2015) conducted a theoretical analysis of a single slope-solar still and the effect of heat capacity of basin and glass cover on it. The research showed that a decrease of heat capacity of basin and glass cover caused a cumulative yield increase of $10.38 \%$ and a decrease in exergy destruction for both basin and glass of $7.53 \%$ and $15.84 \%$ respectively [39]. It was concluded that heat capacity has an inverse effect on productivity. 
To sum up, the productivity of a single-effect solar still is in the range $2-4 \mathrm{~L} / \mathrm{m}^{2}$.day for a rudimentary version, increasing to $3-5 \mathrm{~L} / \mathrm{m}^{2}$.day for versions with improved materials for the basin liner, or optimized geometries. These rather low figures have prompted researchers to introduce further design modifications as discussed next.

\subsection{Solar reflectors}

One approach to improve productivity is to increase the amount of solar energy reaching the still. This can be done using a reflector. Hiroshi (2011) performed experiments in a singlebasin solar still with internal and external reflectors (fig 7). It was found that the distillate yield can be increased by inclining the external reflector backward during summer and forward during the remaining of seasons [40,41]. Boubekri (2011) carried out a numerical modelling study on the yield of solar stills, including the addition of internal and external reflectors in the still, to get an increase in productivity of $72.8 \%$ [42]. The general findings were that the inclination angle for external and internal reflectors should be less than $25^{\circ}$ and that the optimum inclination angle of the glass cover is in the range $10^{\circ}-50^{\circ}$ according to season.

\subsection{Wicked and stepped-basin solar still}

Other approaches involve improving heat and mass transfer inside the still to raise productivity. For example, the use of wicks and/or stepped-basins helps to retain and spread the evaporating water, thus improving the evaporation rate. This approach has been used mainly in single-basin stills as shown in fig 2 . There have been various research studies carried out with respect to heat storage and exergy analysis on stepped type solar stills. For example, Halimeh et al. (2013) conducted a comparative study between energy and exergy efficiency in a stepped type cascade solar still (fig 3) and reported maximum energy and exergy efficiencies of $83.3 \%$ and $10.5 \%$ respectively. It was found that energy and exergy variations are directly proportional to solar irradiation and brine water inlet temperature. The low exergy efficiency implies a considerable destruction of exergy and lost opportunity to obtain useful output; this loss was attributed to the absorber plate mainly which was therefore highlighted as a possible area of improvement [43].

Sadineni et al. (2008) conducted experimental and theoretical investigations in stepped solar still found that the productivity was $20 \%$ higher than in a conventional solar still. Scale formation in absorber plates was also avoided in the modified set up [44]. Nabil (1995) performed an experiment in a stepped solar still by providing a separate condensing unit for the vapour before it reaches the glass cover and found that the overall efficiency was $60 \%$ [45].

Agouz (2015) modified the stepped solar still with continuous flow of water and using a cotton wick and obtained an increase of $48 \%$ in productivity. Samuel (2015) conducted experiments using different wick material such as cotton, wool, nylon, jute cloth, coir mate, charcoal cloth, sponge and water coral fleece and reported that water coral fleece was the best material [46]. Mahdi (2011) designed and constructed a tilted wick type solar still (fig 9) and achieved around $53 \%$ improvement in daily productivity percentage using a charcoal wick [47]. It is concluded that wicks and stepped evaporators can increase productivity by $20-$ $53 \%$. 


\subsection{Fins}

Fins in the base of a solar still enhance the performance by increasing the rate of heat transfer from basin to water [48]. Velmurugan et al. (2008) performed an experiment in a single-basin solar still with various modifications (fig 10) and found that the productivity was increased by $29.6 \%, 15.3 \%$ and $45.5 \%$ for wick, sponge and fins respectively [49]. Velmurugan et al. (2008) also constructed a still with fins to treat industrial effluent. Although fins improved the performance, it was found that greater improvement was obtained using sponge and pebbles [50].

Omara (2011) conducted a set of experiments in conventional, finned and corrugated still. It was found that the still with fins gave $40 \%$ improvement in productivity whereas the corrugated still gave only $21 \%$ more than a conventional still [51].

These studies also showed that the productivity of a finned solar still increases with fin height and decreased with fin thickness, and that too many fins may decrease output.

\subsection{Heat storage}

Another approach to boost performance is heat storage. A heat storage medium absorbs energy during peak sunshine hours and then releases the heat when the radiation decreases. The solar still may thus continue to function after dusk. Various materials have been used to achieve both latent and sensible heat storage. Some researchers placed the heat storage material below the water surface, others submerged inside the basin, while other researchers placed it beneath the basin.

\subsubsection{Sensible heat storage}

Rahim (2003) used an aluminium sheet painted black just below the water surface and thus maintained an output during the nocturnal period with an efficiency of $47.2 \%$ [52]. Velmurugan et al. (2009) analysed the performance of a stepped solar still with sensible heat storage materials inside the basin (fig 5) and found that there was an increase in productivity of about $68 \%$ and $65 \%$ for the still with sponge and pebble materials respectively. The productivity was increased by about $98 \%$ when both pebbles and sponge were combined in a stepped solar still [53]. This result seems to have higher productivity than the stepped solar still with asphalt basin liner [36].

Some materials may provide both heat storage and optical absorption. Salah et al. (2009) predicted the thermal performance of solar still with various absorber materials such as coated and uncoated wire inside the basin and found that uncoated sponge has highest water collection rate [54]. Pankaj (2013) analysed the effect of a floating porous absorber inside the basin in solar still of single slope type (fig 6) experimentally and theoretically and achieved about $68 \%$ of distillate yield with a modified still set up [55]; these results are similar to those of Velmurugan [55] with a single-basin single-slope stepped solar still with sensible heat storage material. Sakthivel et al. (2008) conducted experiments with a single-slope singlebasin solar still by using black granite gravel of size $6 \mathrm{~mm}$ an energy storage medium beneath the basin for various depths of water inside the solar still. The main advantage of using black granite gravel power is to reduce side and bottom losses, and to absorb heat during the day. It was found that there was an increase in yield of about 17-20\% [56]. Other researchers 
focussed on integration of a solar still with roof-mounted thermal energy storage and reported productivity around $3.5 \mathrm{~L} / \mathrm{m}^{2}$.day $[57,58]$.

Kalidasa et al. (2010) fabricated a single-basin double-slope solar still with sensible heat storage material such as quartzite rocks, red brick pieces, cement concrete pieces, washed stone and iron scraps and inferred that quartzite rock gave the highest output [59]. Kalidasa et al. (2011) extended the research with various wick material (fig 13) and minimum mass of water in the still [60]. Kalidasa et al. (2008) conducted an experiment on a passive type double-slope single-basin solar still with a thin layer of water in the basin, using washed natural rock as porous material. It was concluded that an increase in temperature difference between glass and water increases the productivity [61].

\subsubsection{Latent heat storage}

Latent heat storage was achieved using phase change materials (PCM). Omar et al. (2013) [62] conducted experiments in a solar still with PCM beneath the basin (fig 4) and found that it enhances both the productivity and efficiency of the still; however no specific performance was reported to enable comparisons. Abdulhaiy (2004) also positioned PCM (paraffin wax) beneath the basin in a stepped solar still. It was concluded that efficiency was about $61 \%$ and productivity was about $4.9 \mathrm{~L} / \mathrm{m}^{2}$.day [63]. This efficiency was high compared to the results of Rahim and of Zurigat who reported $47.2 \%$ and $25 \%$ efficiency respectively also [52, 53] (fig $31)$.

Sebaii et al. (2009) has performed an experiment with and without PCM beneath the basin. It was found that the PCM caused a $27 \%$ increase in evaporative heat transfer coefficient whereas the convective heat transfer coefficient is doubled [64]. Mohammad et al. (2011) carried out a thermal analysis on stepped solar still with PCM of paraffin wax beneath the absorber plate which also improved productivity. They also observed there was an increase in the residence time due to the distribution of water on evaporation surface [65].

Swetha et al. (2011) conducted experiments with a single-slope solar still using PCM of lauric acid beneath the basin and found that the distillate production increased up to $36 \%$ [66]; this is in contrast with the findings of Silakhori (2011) indicating that paraffin wax and acetamide are more stable (see section 6). In conclusion, latent heat storage gave greater output [67] and the PCM must be selected with low melting point around $30-45^{\circ} \mathrm{C}$ [68] to match the low operating temperatures of passive stills. The best position for the heat storage material is beneath the basin and the best materials are paraffin and acetamide.

\subsection{Unconventional shapes}

A conventional solar still, as shown in fig.2, is rectangular in plan view and trapezoidal in elevation. However, a number of other shapes have been reported for use in passive solar stills as discussed below [69-94].

\subsubsection{Triangular stills}

Several researchers conducted various analyses on triangular solar stills such as thermal analysis, exergy analysis and parametric analysis. Eduardo et al. (2002) analysed the thermal performance of condensing cover in the triangular solar still and found the optimum orientation to be east-west [69]. Fath et al. (2003) also made a thermal analysis by comparing a pyramid design against a single-slope solar still but found the yearly performance of the 
pyramid design to be worse. The optimum angle for the pyramid glass cover is $50^{\circ}$ to achieve maximum productivity [70]. Kianifar et al. (2012) carried out an exergy analysis in a pyramid type solar desalination system with and without fan on the side of the glass. It was found that the evaporation rate increased for the system with fan (fig 21) and daily productivity increased by about $15-20 \%$ and the exergy efficiency was higher for lower depth of water [71].

Ahsan (2014) conducted parametric analysis in a passive triangular solar still (fig 19) by varying the depth of water and other climatic parameters. It was inferred that depth of water has an inverse effect on the daily productivity [72, 73]. Ravishankar et al. (2014) conducted experiments in a triangular pyramid still (fig 18) and discussed the factors which affect the performance. It was inferred that productivity was maximum for the minimum depth of water and wind speed must be around $4.5 \mathrm{~m} / \mathrm{s}$ to achieve a $15 \%$ productivity increase (see section 2) [21].

Reflectors have also been used with triangular solar stills. Arunkumar et al. (2010) made a study on thermo physical properties such as thermal conductivity and dynamic viscosity in pyramid type solar still with mirror boosters (fig 20) and the resulting values were found to be $29.64 \times 10^{-2} \mathrm{~W} \mathrm{~m}^{-2} \mathrm{C}^{-1}$ and $20.2 \times 10^{-6} \mathrm{~N} \mathrm{~s} \mathrm{~m}^{-2}$ respectively [74]. A key finding from this research was that the distillate yield increases from 1.52 to $2.9 \mathrm{~L} / \mathrm{m}^{2}$.day with the mirror booster.

The overall conclusion is that, even though triangular solar stills may improve the yield over certain days, they have no advantage when we consider yearly performance because of the radiation losses.

\subsubsection{Tubular stills}

Tubular solar stills are intended to simplify construction. Amimul et al. (2010) modelled a tubular solar still with heat and mass transfer models with formulation of new equations for humid air as an addition to the conventional equations. Zhili (2013) carried out experimental research with three tubular solar stills and found that yield increased as the temperature increases [76]. Nader Rahbar et al. (2015) analysed the convective heat transfer coefficient and water productivity using computational fluid dynamics and inferred that glass temperature and water temperature have an inverse effect on the still performance [77].

With regard to the cover material, initially Islam (2009) fabricated a tubular solar still with a vinyl chloride cover and with a lightweight polythene sheet and found that the productivity was low for the still with vinyl chloride cover due to the stagnation of condensed water in the still. [78]. Amimul et al. (2012) conducted experiments on a tubular solar still with polythene film by modifying the trough arrangement; the research also included determination of a linear relation between heat transfer coefficients and mass transfer coefficients [79]. The lightweight polythene cover improved the average cumulative condensation mass transfer coefficient to $305 \mathrm{~W} / \mathrm{m}^{2} \mathrm{~K}$ thus improving productivity.

\subsubsection{Hemispherical stills}


Hemispherical covers have been used with the intention of increasing the amount of solar energy collected by the solar still. Arunkumar et al. (2012) conducted an experimental study on a hemispherical solar still (fig 26) with and without flow of water over the cover. It was found that there was $42 \%$ increase in efficiency for a still with water flow, while the efficiency was only $34 \%$ for the still without water flowing on the cover [80]. Ismail (2009) fabricated a transportable hemispherical solar still (fig 27) and concluded that the efficiency of the still decreased by $8 \%$ when the saline water depth increased by $50 \%$ [81]. This result is similar to the efficiency attained by Aboul [34] in double- and triple-basin solar stills with pyramid cover, but a stepped solar still with a condensing unit developed by Nabil et al [45] gave better efficiency than the hemispherical solar still (fig 30) [80]. When, however, we compare the efficiency with a standard-single-slope single-basin solar still built by Panchal [27], hemispherical solar still gives better efficiency. The key findings regarding hemispherical solar stills are that the water depth has an inverse effect with productivity and efficiency; moreover the regenerative effect increases the distillate output. Further research could be done by integrating a reflector with the still to achieve better performance.

\subsubsection{Multiple slopes}

Like hemispherical solar stills, multiple-slope solar stills can be used to capture sunlight from various directions. Various studies were carried out on double slope solar still with respect to heat storage, parametric variation, heat loss coefficient and orientation.

Parametric variation plays a vital role in the efficiency of the system. Researchers have investigated design, operational, climatic and non-dimensional parameters. Hinai (2002) analysed the productivity of a multiple-slope solar still with variations in climatic, operational and design parameters. Optimal values of the cover tilt angle and insulation thickness were found to be $23^{\circ}$ and $0.1 \mathrm{~m}$ respectively in a study carried out in Oman [82]. Rahul et al. (2011) derived the characteristic equation for a double slope passive solar still with nondimensional parameters such as instantaneous efficiency and tested the still in the climatic condition of Delhi. The result infers that linear characteristic curves are less accurate than non-linear characteristic curves [83]. Hanane et al. (2012) conducted experiments using a double-slope solar still for desalination of seawater by considering various operating parameters such as water and glass temperature. It was inferred that, for higher temperature difference of water and glass, higher yield was obtained and the productivity yield per day was $4 \mathrm{~L} / \mathrm{m}^{2}$.day [84] which agrees with the result of Kalidasa (2008) [85]. The productivity range was similar to productivity range of a single-slope regenerative solar still with jute cloth.

Rajamanickam et al. (2012) conducted an experiment in a double slope solar still and analysed the influence of the depth of water on internal heat and mass transfer coefficients. It was inferred that $3.07 \mathrm{~L} / \mathrm{m}^{2}$.day for the depth with $0.1 \mathrm{~m}$ gives more productivity, but this productivity shows the contrast result with the research work of Hanane (2012) with 4 $\mathrm{L} / \mathrm{m}^{2}$.day in a double-slope solar still [86]. Trad et al. (2013) carried out a comparative study of a symmetric solar still with double slope vs. an asymmetric solar still (fig 12). It was inferred that asymmetric solar still with north-south orientation gives more efficiency than symmetric one with double-slope [87]. 
The key findings about simple double-slope solar still are that, to achieve high productivity, optimum water depth must be maintained and that the still must be asymmetric with southnorth orientation.

\subsubsection{Vertical stills}

Most solar stills are of horizontal type, in the sense that the width and breadth dimensions are much larger than the height dimensions. Vertical solar stills, which are tall in shape, have also been evaluated. Minasian et al. (1992) proposed a vertical still of floating type for use in marsh areas. A cotton wick was added inside the glass and the wick was allowed to become immersed completely in the brine [88]. The study of various parameters such as saline water input, output temperature of still, ambient temperature, glass cover temperature and productivity of still, inferred that the performance depended on solar radiation, ambient temperature and finally the solar orientation [89]; and that with the flat plate reflector (fig 29 ), there was an increase in productivity [90].

Boukar et al. (2003) also conducted experiments in a vertical solar still (fig 28) and found that the still orientation plays a major role in absorbing solar energy for attaining maximum yield [91]. The main findings in vertical type solar still are that the still gives low productivity (around $1.31 \mathrm{~L} / \mathrm{m}^{2}$.day) and the overall efficiency is also very low $(21.1 \%)$ which implies that this type of solar still is not suited for attaining effective desalination output [91]. However, multi partitions in a vertical solar still have given productivity up to $3.45 \mathrm{~L} / \mathrm{m}^{2}$.day [93, 94]. Even then, the range is much less compared to some horizontal type solar stills such as single-basin single-slope solar stills with condenser, single-basin triangular solar stills, single-basin stepped solar stills, single-slope regenerative solar stills with jute cloth, double-slope solar stills, double- and triple-basin solar stills, double-slope solar stills with rotating cylinder (fig 14) and condenser; however, the productivity is high compared to single-basin greenhouse type double-slope solar still, single-basin triangular solar still with fan and mirror booster (fig 30). It is concluded that vertical solar stills generally give low outputs and are only suitable for specific applications where a low footprint is required.

\subsection{Multiple-effect passive solar stills}

Multiple-effect solar stills can greatly increase productivity by reusing the heat of condensation to evaporate water repeatedly. Multiple-effect solar stills can be of multi-wick or multi-basin type.

\subsubsection{Multi-wick solar stills}

Sodha et al. (1981) analysed a multi-wick solar still with blackened wet jute cloth to intercept maximum solar radiation. The analysis is based on Dunkle's relation and showed up to $34 \%$ efficiency for multi-wick solar stills. This represents a $4 \%$ increase in efficiency as compared to basin type still [95].

\subsubsection{Multi-basin solar stills}

Other researchers analyse the performance and productivity of multi-effect solar stills using multiple basins. By means of a theoretical model based on ordinary differential equations, Sangeeta et al. (1998) found that the optimum number of basins was 7 in an inverted absorber still [96]. To find the effect of inclination angle in a multiple-effect solar still, Tanaka (2002) performed an experimental study on a single-basin type multiple-effect diffusion-coupled 
solar still with the reflector at the bottom, and found that the distillate yield was $13 \%$ greater than that of a conventional type solar still $[97,98]$. The best inclination angle was reported to be $23^{\circ}$ for a multi-effect still situated in Muscat, Oman (latitude angle 23.61 ${ }^{\circ}$ )[99].

Hilal et al. (2004) compared the productivity of a multi-basin against a single-basin still and attributed the higher productivity in the multi-basin still to the fact that heat loss in the bottom basin is reduced by the top basin [100]. Sebaii (2002) analysed the productivity of triplebasin solar still (fig 24). It was concluded that the daily productivity of the still was inversely proportional to the water mass in each basin. The productivity increased to $12.6 \mathrm{~L} / \mathrm{m}^{2}$.day [101], more than with any single- or double-basin still. A plastic double-basin solar still (fig 23) had very low productivity and efficiency [102] [103]. A study to analyse the effect of a condenser on a multi effect solar still (fig 22) was carried out by Madhlopa et al. (2009) who inferred that the distillate productivity with the modified still was $62 \%$ higher than with the conventional type still [104].

The key finding here is that, to achieve higher productivity, multiple-effect solar stills are recommended. The disadvantage is the increased maintenance effort and costs typically associated with the additional basins.

\section{Active solar stills}

In active solar stills, additional components such as solar collectors, condensers, coolers or other equipment are added to boost the performance. Typically this equipment requires pumps, fans or other powered devices for its operation. Thus unlike passive solar stills, active solar stills typically require electricity.

\subsection{Solar collectors}

External solar collectors may be used to complement or replace the collector surface of the still. In the literature, the uses of various types of collectors have been reported as follows.

\subsubsection{Flat plate collectors}

The use of a collector increases the heat input to the still; therefore it may also be necessary to enhance the heat output to achieve condensation. This has been done using a humidifying tower and condensing cover. Farhad et al. (2015) analysed exergy and energy for solar desalination system with a flat-plate solar collector by both experimentally and theoretically and found that there was a decrease in exergy efficiency by increasing the length of the humidification tower and that the exergy efficiency increased with decrease in inlet air temperature and tower diameter [105]. Dimri (2008) conducted an experiment with effect of condensing cover with the yield of active solar still and inferred that productivity was directly proportional to the thermal conductivity of material of the condensing cover. Thus copper results in greater yield compared to glass and plastic, due to its higher thermal conductivity [106]. Tiwari et al. (1996) made an analysis to relate instantaneous thermal efficiency and collector area. In this research the energy balance for each component was considered and the research ended with the formulation of equations for the various components of the still [107].

As with passive solar stills, the shape of the solar still may influence the performance but in a different way. Arslan et al. (2012) performed experiments in various solar stills such as circular box solar still, rectangular box solar still and single tube solar still coupling with 
solar collector. It was inferred that circular box solar still gives a better efficiency compared to a single tube or rectangular box [108]. This contrasts with the findings for passive solar stills where the optimum shape was found to be rectangular. This may be explained by the lower heat loss from the circular box due to its reduced surface area.

External collectors have also been used together with other performance enhancement techniques (similar to those used for passive solar stills) such as stepped evaporators, mirrors and heat storage materials. Rajaseenivasan (2014) integrated flat plate collector (fig 30) with modified solar still having jute cloth and black gravel to enhance the evaporation rate and heat capacity of the still which increases the distillate yield of about $60 \%$ with that of conventional type [109]. Boubekri found that the distillate yield in single basin single slope solar still with jute cloth and flat plate collector gives more than single basin single slope solar still with collector. Kabeel et al. (2012) carried out an experimental study alongside theoretical modelling for a stepped evaporator with flat plate collector (fig 40) for desalination process. It was inferred that pre heating of feed water enhances the productivity to a small extent, but also reduces the system efficiency [110]. Badran et al. (2007) developed an experimental setup in a single-slope solar still, with a mirror fixed to its inner side, coupled with a flat plate collector, and increased the productivity by $36 \%$ [111]. The productivity increase in various active solar stills is represented in fig 50; however, the productivity of the solar still with mirror developed by Badran [111] was low compared to a single-basin single-slope solar still with flat plate collector [112, 113]. Shiv et al. (2009) analysed the productivity of single slope hybrid solar still and found that the hybrid solar still productivity was 3.5 times more than that of the passive solar still [114].

In addition to external collectors, internal collectors have also been used by various researchers to increase the thermal performance. Salah et al. (2008) evaluated the performance of an internal solar collector coupled to a single-slope stepped solar still with various modifications such as a reflecting mirror inside the basin, coupled with a sun-tracking system. This resulted in an enhancement in thermal performance in the range 30\%-380\% [115]. The overall key findings on the use of flat plate collectors are that the collector, along with the addition of reflectors and copper condensate cover, increases the evaporation rate and productivity yield of the desalination system.

\subsubsection{Evacuated tube collectors}

The evacuated tube collector has multiple evacuated glass tubes and internal absorber surfaces. Shiv et al. (2014) fabricated a single slope solar still and integrated with a forcedmode evacuated tube collector (fig 32) and found that the temperature and the yield increased for the integrated model and attained energy efficiency of about $33.8 \%$ [116]. In contrast, Eugenio et al. (2007) analysed the performance of an integrated solar-still evacuated tube collector and concluded that the fresh water production was low for the integrated model compared to the conventional model [117].

\subsubsection{Solar ponds}

The solar pond has three zones namely an upper convective zone, non-convective zone, and lower convective zone. The solar pond is used to store the thermal energy. Solar pond integration with the still helps in preheating the feed water and hence there is an enhancement in productivity. Various researchers tried to analyse the productivity of stills with solar ponds 
with respect to various modification as discussed below. Velmurugan et al. (2007) fabricated a solar still coupled with a mini solar pond (fig 35) and conducted experiments with various modifications such as addition of sponges to the still. The results indicate that the still with sponge integrated with mini solar pond has higher production rate compared to other options [118-120]. Sebaii et al. (2011) analysed the thermal performance of an active single-basin solar still coupled to a shallow solar pond, and concluded that the productivity and the efficiency was more than that of the conventional still and that the system can be used as a source of hot water for different applications [121].

\subsubsection{Concentrating collectors}

A solar concentrator absorbs the sun's rays from a large area and focuses them to the small receiver area. This helps in boosting the desalination process in the still. The research has been done to analyse the performance and productivity with respect to wind speed, ambient temperature and solar radiation. Javad et al. (2011) conducted an experimental study in concentrators coupled active solar still and inferred that fresh water productivity was inversely proportional to the wind speed and the productivity increased with ambient temperature and solar radiation [122]. Zeinab (2014) conducted experiments in solar desalination with a modified setup using a solar parabolic trough concentrator (fig 44) and found that the productivity yield increased by about $18 \%[123,124]$.

Researchers also tried concentrators with heat storage. Arunkumar et al. (2013) fabricated a concentrator-coupled solar still with and without PCM (fig 33). The productivity yield increased by $26 \%$ (fig 50) with the PCM [125]. Another study by Arunkumar (2011) showed increased productivity through use of the concentrator [126]. Farshad et al. (2010) also investigated a concentrator coupled solar still integrated with heat reservoir (fig 42) for producing fresh water during night and cloudy days [127]. They reported 12\% water production was achieved during the nocturnal period.

The overall findings about solar stills with concentrator are that the hourly productivity of the still can be increased by the addition of PCM.

\subsubsection{Air heater}

The coupling of an air heater to the solar still increases the water temperature in the basin and thus promotes the evaporation rate. Sampathkumar et al. (2012) carried out a study on various active solar stills and found that the air heater increased productivity by up to $70 \%$ [128]. This productivity is high compared with that of stills coupled with flat plate collectors, evacuated tube collectors and concentrators. Various design modifications such as heat storage, and water spraying have been done on solar stills, with air heater to achieve higher productivity. To investigate the effect of heat storage, Abdulha (2013) performed an experiment in a stepped solar still, with solar air heater and latent heat energy storage, and proposed a method for increasing the performance by adding aluminum filling as a heat storage medium beneath the absorber. It was found that the integration gave $53 \%$ more productivity than a conventional set up [129]. Zahaby et al. (2011) did an experimental study to enhance the performance of air heater-coupled solar stills using a reciprocating water feed system and attained efficiency $77.4 \%$ [130]. The key findings from these works were that the 
still with integrated air heater gives higher efficiency and productivity only when combined with thermal energy storage and water spraying arrangements.

\subsection{Enhanced condensers}

\subsubsection{Internal condenser}

The addition of a separate condenser increases the condensation rate inside the solar still and increases the productivity of fresh water. The research has been conducted to improve the productivity, efficiency and yield of solar still integrated with internal condenser. Ahmed made an experimental study on a solar still with internal condenser in a single-effect solar still and found that the productivity was increased by about 30\% than the conventional [132]. Nabil (1995) conducted experiments using a forced condensing system to improve the transparency of glass cover and efficiency [45]. A separate evaporator as well as condenser (fig 37) increases the difference in temperature between evaporator and condenser and hence the productivity [131]. The key finding from this study is the addition of internal condenser increases the productivity from $5.5 \mathrm{~L} / \mathrm{m}^{2}$.day to $5.9 \mathrm{~L} / \mathrm{m}^{2}$.day $[132,133]$. Mohamed et al. (2002) conducted the numerical study of double slope solar still with condenser (fig 16) to increase the distillate yield of the system and found that there was $55 \%$ increase in productivity [134] which gives similar result with single slope solar still with hot water sprayed circulation and passive hot water sprayed circulation by Mohamed.

\subsubsection{External condenser}

The external condenser improves the condensation rate of the active still. Kabeel et al. (2004) integrated external condenser to the still (fig 38) and suspended nanoparticle in the water to enhance heat transfer properties, evaporative properties and reducing the convection heat loss from basin to glass cover. The results inferred that the effect of adding condenser with Nano fluid suspension in water increases the distillate yield by $53.2 \%$ and $116 \%$ respectively [135]. Kabeel et al. (2004) focussed on increasing the performance of solar still by using nanoparticles such as cuprous oxide and aluminium oxide in the basin with and without vacuum and found that cuprous oxide increases the productivity by $133.6 \%$ while aluminium oxide increases the productivity by $125 \%$. Thus the addition of an external condenser and together with use of nanoparticles improved the heat transfer rate of the system.

\subsubsection{Regenerator}

Regeneration recovers the heat from glass; thereby it enhances the condensation also preheating the feed water. Mousa et al. (2005) made a comparative study on three types of still namely a conventional solar still, a regenerative still and double-glass still. It was found that regenerative solar still gives more than $70 \%$ higher productivity than the conventional still [136]. Sakthivel et al. (2010) fabricated a regenerative solar still with energy storage medium of jute cloth (fig 11). The main aim of this research was to increase the evaporating surface area by introducing energy storage medium (jute cloth) and thus the latent heat of condensation was utilized. It was found that, when there was an increase in temperature difference between glass and water, the daily productivity increased by $12 \%$ and the efficiency of the system increased to $52 \%$ giving $4 \mathrm{~L} / \mathrm{m}^{2}$.day [137]. Prakash et al. (1986) 
predicted the performance of a regenerative solar still in ideal conditions as $7.5 \mathrm{~L} / \mathrm{m}^{2}$.day [138].

Sanjay et al. (1996) coupled a concentrator with a regenerative solar still and found that the overall thermal efficiency was directly proportional to the flow rate of cold water over the glass cover [139]. Singh et al. (1993) studied thermal performance of regenerative solar distillation (fig 41) with a thermosyphon in Delhi's climatic conditions. It was concluded that there was an increase in performance of distillation with the flow of water over the glass cover [140]. Sinha et al. (1994) integrated a regenerative solar distiller with aspirator and found that the thermal efficiency was directly proportional to the flow of air velocity [141].

It is concluded that the regenerator generally gives higher productivity than a single-basin single-slope solar still with condenser. In the regenerative active solar, total heat loss is reduced, directly improving the productivity and efficiency.

\subsection{Enhanced heat and mass transfer \\ 4.3.1 Rotating shaft}

The purpose of adding a rotating shaft is to break up the thermal boundary layer of water in the basin, which in turn increases the vaporisation rate and condensation rate. Abdel-Rehim et al. (2005) modified a still by placing a rotating shaft near the basin water surface (fig 8) thus improving the performance of the still [142]. The research found that high productivity was achieved during the month of July with a modified still setup when compared to the other months. Wind turbines have also been used in solar still to rotate the shaft, thus increasing the distillate yield. For example, Mohamed et al. (2009) used a 3-cup wind turbine to drive a submerged shaft carrying impellers (fig 34). It was inferred that productivity was inversely proportional to water depth because of decrease in water temperature [143]. They also found that the rotating shaft gave rise to vibrations which encouraged droplets to run off the cover into the collection channel.

\subsubsection{Chimneys and cooling towers}

The integration of a solar chimney enables both power and fresh water to be produced (fig 36). The research findings from a single-basin single-slope solar still with chimney were, however, that productivity was sacrificed during periods of strong radiation [144].

A cooling tower decreases the condensate temperature, and thereby increases the temperature difference between glass and water, resulting in higher productivity. Hichem et al. (2009) conducted a theoretical study on the effect of a cooling tower on a desalination unit, and they discussed the effect of mass flow rate on pure water production with and without the cooling tower integrated with collector. It was concluded that the production increased with the decrease in temperature of the cooling tower, and decreased with the decrease in absolute humidity in the cooling tower [145].

\subsubsection{Vibratory Harmonic effect}

The vibratory harmonic effect is a novel approach to performance enhancement, whereby the boundary layer of saline water and surface tension of brine water is disturbed by means of a 
vibrator to increase the evaporation and condensation rate. It has been tried in double slope solar still by Khaled et al. (2010) (fig 15). A flexible stretched medium was used in the bottom of the basin together with a vibrator (resonator) to improve the efficiency by $60 \%$ [146]. The key findings from this research were that, in addition to the increase in convective heat transfer coefficient, vibrations also help encourage droplets to run off the glass for collection (as with the rotating shaft).

\subsection{Photovoltaic-thermal stills}

Hybrid solar stills including photovoltaics have been built. Shiv Kumar et al. (2008) carried out an experimental study on an active solar still with integrated photovoltaics and reported an output 3.5 times higher than for a passive solar still [147]. Rahul et al. (2010) did an experiment combining the flat plate collector and PV with an active still and also presented a mathematical model for the system [148]. The main findings from this research were that the water depth only produces minor effect on distillate yield and major effect on efficiency of active solar still with an increment in exergy efficiency to $2.6 \%$. Gajendra et al. (2011) conducted an experiment in a double-slope active solar still with a solar photovoltaic-thermal system (fig 43) and found that the production rate was increased up to 1.4 times above that of a still with single-slope photovoltaic thermal technology [149].

The addition of wick increases the incident radiation inside the still. Omara (2002) conducted an experiment on a hybrid solar desalination system with a single layer wick and double layer wick (fig 39) and found that double layer solar wick gives an average daily efficiency of about $71.5 \%$. The experiment was validated with a theoretical model and there was an acceptable agreement between experimental and theoretical values [150]. The key finding from this research was that, the increase in operating temperature of the solar still increases the efficiency of the solar still, and it is better to use a double layer wick instead of a single layer wick to achieve better efficiency.

\subsection{Multiple-effect active stills}

As in passive solar stills, multiple basins can be used to achieve multiple effects at vapour from one basin can be condensed on the underside of another basin, thus releasing heat to drive further evaporation.

Elango et al. (2015) performed an experiment to analyse the relation between water depth and productivity in a double-basin solar still (fig 45). The results showed that the double basin yields more distillate only when the water depth was maintained at just $1 \mathrm{~cm} \mathrm{[151].} \mathrm{This} \mathrm{is}$ inconsistent, however, with the results of Manivel et al. [53] and Sakthivel et al. [56] who achieved higher yield with 2.5 or $3 \mathrm{~cm}$ water depth. Hitesh (2013) conducted the experiment in a double-basin solar still with a vacuum tube (fig 46) and black gravel granite attached to it. The results showed that, when the still is coupled with both vacuum tube and granite, the system gives higher productivity, than when coupled separately [152]. The overall findings in a double-basin solar still are that optimum water depth with vacuum tube and granite yields the highest productivity.

Research and development in multi-effect solar stills has integrated solar stills with solar collectors, evacuated tube collectors and solar water heater parabolic reflector tube absorbers. Nishikawa et al. (1998) fabricated solar desalination system integrated solar collector with three effects for desalinating sea water (fig 47). The maximum fresh water productivity was 
$9.44 \mathrm{~L} / \mathrm{m}^{2}$.day [153]. Ahmed (2009) fabricated multistage solar distillation system with an evacuated collector (fig 48) for the purpose of increasing efficiency and productivity [154]. Reddy et al. (2012) analysed the performance of evacuated collector multi stage solar water desalination system, and plotted the effect of various parameters such as number of stages, mass flow rate, gap between the trays, salinity, temperature difference between the stages and pressure on the distillate yield [155] and it was found that the distillate yield increased with the integration of an evacuated tube collector. Sanjeev et al. (1999) used the Runge-Kutta method to determine the performance of a triple-basin solar still [156].

Mahkamov (2008) carried out a performance study on a multi-effect still with evacuated tube collector and analysed the performance of the system to infer that the thermal performance was twice that of a conventional still [157]. Baharna et al. (1993) integrated a solar water heater with a triple-basin solar still, thus enhancing daily distillate yield. It was inferred that yield was doubled and the maximum productivity was obtained when the surface areas of solar water heater and triple-basin solar still were equal [158]. The productivity of multi-stage solar still also depends on various climatic parameter and surroundings. Elsafty et al. (2008) developed a mathematical model for solar stills with parabolic reflector tube absorber. The study includes effect of various parameters such as solar intensity, ambient temperature, reflector aperture area, reflectivity of reflector material, wind velocity and evaporation area with productivity [159]. The key findings from this research are that, wind velocity, condenser emissivity, condenser thickness and saline water depth were inversely related to productivity; whereas ambient temperature, solar intensity, evaporation area are directly proportional to the productivity.

\section{$5 \quad$ Greenhouse type solar still}

The principal of the greenhouse type solar still relies on the fact that radiation in the wavelengths between $400-700 \mathrm{~nm}$ only is required for photosynthesis and the remaining part of the solar spectrum, which includes the infrared, can be used for desalination. Since water is a good absorber of infrared radiation, a passive basin solar still can be incorporated into the greenhouse roof to provide a selective optical filter. Using this approach, Okujagu (2008) investigated the use of single-effect greenhouse type solar still for converting brine water to fresh water in the Riverine region in Nigeria delta [160]. Eugenio et. al (2008) attributed the reduced output of a greenhouse solar still, compared to a conventional still, to the use of the transparent basin (fig 17) $[160,161]$. Because of this transparency, the radiation absorbed inside the solar still reduces which in turn decreases the water temperature and productivity. The partial vapour pressure in the basin and cover affects the productivity of fresh water [162]. In general the productivity in greenhouse solar stills is reduced to $1.6 \mathrm{~L} / \mathrm{m}^{2}$.day, which is 2 or 3 times less than a conventional still.

In addition to passive types, active greenhouse solar still have also been designed. Voropoulus et al. (2004) for example, coupled a greenhouse still with a solar collector and hot water storage tank, and found that the system was effective for attaining maximum productivity compared to a conventional system [163] [164].

So far greenhouse stills seem unfit for commercialisation unless the costs can be substantially offset by integration with the greenhouse. Otherwise it may be better to install solar stills separately alongside greenhouses to provide the irrigation water required for cultivation. 
As seen in section 3, productivity is influenced by the wick material and type of heat storage material incorporated in a still. Phase change materials like paraffin wax and acetamide are very promising to improve performance [165]. The world is marching towards the new revolution of nanoparticles for improving thermal properties like thermal conductivity and heat transfer characteristics of PCM [166]. Nanoparticles are already finding use in water treatment [167-170], agro-food [171], fuel cells [172] and other applications [173].

Some of the relevant research in this area includes, incorporation of $\mathrm{TiO}_{2}$ nano particles with stearic acid as PCM carried out by Harikrishnan et al. (2012) who found that thermal stability and thermal conductivity of PCM increased with the incorporation of nanoparticles $[68,174-$ 176]. Additionally the research extended to the incorporation of $\mathrm{CuO}$-nanoparticle with oleic acid as the PCM for cooling application, resulted with the good improvement in cooling properties $[177,178]$. $\mathrm{TiO}_{2}$ with paraffin was found to have good stability compared to $\mathrm{Al}_{2} \mathrm{O}_{3}$, $\mathrm{SiO}_{2}$ and $\mathrm{ZnO}$ [179]. Parameshwaran et al. (2013) improved the thermal properties of organic ester as PCM with silver nanoparticles. It was found that the incorporation of the nanoparticle increased the thermal conductivity from 0.278 to $0.765 \mathrm{~W} \mathrm{~m}^{-1} \mathrm{~K}^{-1}$ [180]. Song et al. (2007) improved the thermal stability of composite PCM micro capsules, incorporating silver nanoparticles [181, 182].Yang (2014) used $\mathrm{Si}_{3} \mathrm{~N}_{4}$ nano particle to enhance the thermal performance of PCM. It was found that thermal conductivity and thermal diffusivity of the PCM were increased by 35 and $47 \%$ respectively with the incorporation of $10 \mathrm{wt} \%$ nanoparticle [183]. To achieve excellent rate capability and cycle performance in low temperature applications, Zheng et al. (2015) used nano- $\mathrm{LiFePO}_{4} / \mathrm{C}$ cathode materials and found that these materials exhibit better electrochemical properties and gives a specific capacity of $130 \mathrm{mAh} \mathrm{g}^{-1}$ under $0.1 \mathrm{C}$, at $-20^{\circ} \mathrm{C}$ [184]. Nanocompositives have also been used beneficially in electrical capacitors [185]. So it is concluded that the thermal and heat transfer characteristics will be increased when nanoparticle is incorporated in PCM; moreover when this is extended to the application in solar desalination stills, this will result in high productivity and efficiency along with an increase in yield time through the night.

For cold storage applications, Yutang et al. (2013) used polystyrene/n-tetradecane composite nano-encapsulated PCM and found a reliable increase in thermal conductivity from 0.72 to $0.84 \mathrm{~W} / \mathrm{mK}$ [186]. San et al. (2015) found that $n$-tetracosane and $n$-octadecane have good thermal stability with $156 \mathrm{~kJ} / \mathrm{kg}$ latent heat capacity for low temperature applications [187]. Park et al. (2014) used magnetic $\mathrm{Fe}_{3} \mathrm{O}_{4}$ with paraffin, and found that the addition of nano particle increases the thermal property of phase change material and decreases the super cooling degree of phase change material [188]. For space heating application, Halawa (2011) carried out thermal analysis of PCMs and the result suggested that the charging and discharging temperature difference plays an important role on melting and freezing characteristics [189].

To achieve high thermal conductivity of paraffin wax, graphene oxide may be added. Mehrali et al. (2013) carried out a thermal analysis with incorporation of graphene oxide with paraffin and found that, the thermal conductivity rises to $0.9 \mathrm{~W} / \mathrm{m} \mathrm{K}$ [190]. Wang (2014) found that graphene oxide increases the thermal conductivity of n-eicosane/silica phase change material [191]. Mohammad (2013) found that, graphene oxide increases the thermal conductivity of 
palmitic acid to three times than that of the initial thermal conductivity. Rakib et al. analysed the thermal conductivity of cyclohexane with $\mathrm{CuO}$ and FeNano particles and also found that there was an improvement in thermal properties [192, 193]. The research extended to the calculation of heat transfer rate and concluded that nano-PCM inside an enclosure with higher porosity requires larger energy to melt than the one with low porosity. For the purpose of incorporating exfoliated graphene with paraffin, Shani (2007) conducted an experiment with various mass fractions of exfoliated graphene and found that $10 \%$ mass fraction of was best suited for incorporation with paraffin because of its stable properties, good melting temperature and latent heat storage capacity [194]. To achieve higher heat transfer characteristics of paraffin wax, Zhao et al. (2010) incorporated metal foams and they observed an increased solidification rate [195]. Mettawee et al. (2007) used aluminium powder with wax to improve the thermal conductivity and it was observed that the addition of 0.5 mass fraction of aluminium reduced charging time by $60 \%$; also it was found that there was an increase in heat gain by the mixture [196]. Paraffin which contains $3 \%$ aluminium nitrate PCM improves thermal stability and prevents thermal decomposition [197]. Carbon nanotubes can be also used for desalination application [198] such as reverse osmosis and membrane separation; further carbon nanotubes can be used to desalinate water and for other liquid based separations [199, 200], membrane distillation [201]. They also improve electro chemical properties [202]. Goh et al. (2015) initiated nano-enabled membrane desalination technology indicating that the research gap of nano-material in the area of desalination [203]. $\mathrm{ZnO}$ nano particles with polyvinylidene fluoride improves the mechanical properties, thermal stability and photo-catalytic self-cleaning properties [204]. It was found that the charging and discharging rate is also enhanced when nanoparticles were embedded in the PCM.

In general, the tendency for nanoparticles to improve the stability of PCMs could be used to advantage in solar still applications. Researchers are only just beginning to address the theoretical and practical issues of implementing PCM-nanoparticles in solar stills.

\section{$7 \quad$ Economic analysis of solar stills}

Some authors have concluded that desalination using solar stills is an economically efficient technique [5-7]. Despite the numerous research papers available in the area of solar stills, only very few include any cost analysis. The economic details and other inferences from these papers are summarized in table 2 . As can be seen, the costs vary considerably according to location and availability of materials for construction. 
Solar stills offer to provide solar-powered desalination based on essentially simple principles whereby solar energy drives directly the evaporation of water. However, the goal of implementing solar stills at commercial scale remains elusive mainly because of their limited output. For successful implementation, researchers continue to investigate a wide range of innovations in solar stills, based on operating parameters, geometry, system configuration and materials.

Operating parameters include climatic parameters, not directly under the control of the designer, but which can influence the siting of the solar still. For example, wind speed tends to increase output up to wind speeds of $4.5 \mathrm{~m} / \mathrm{s}$, after which there is no further increase. Another significant parameter is water depth, which should generally as small as possible, while maintaining sufficient water to prevent the still from drying out. Feed water temperature and quality can also affect output. With optimised parameters the maximum output expected from a simple single-effect solar still is about $5 \mathrm{~L} / \mathrm{m}^{2}$.day. This output can be increased using wicks or absorbers, such as jute cloth or black granite gravel. Nevertheless those modifications have never yielded productivity of more than $6.5 \mathrm{~L} / \mathrm{m}^{2}$.day.

As regards geometry, it is advisable to choose the slope angle of the glass correctly. In this respect, however, different studies gave slightly different recommendations: sometimes slope angle is chosen equal to the latitude angle and sometimes it is greater. Unconventional shapes like multiple slopes, tubular, hemispherical and triangular stills have been tried - but without demonstrating clear advantages. Fins, corrugations, and particles (e.g. pebbles) is another way to modify the geometry of solar stills in a way that enhances heat transfer and performance with notable success. These modifications can include judiciously chosen materials, to introduce heat storage, optical absorption enhancement and insulative properties. Latent heat storage is generally more effective than sensible heat storage, and the emergence of nanomaterials combined with phase change material (PCM) is especially promising for heat storage. There are several ways to position the heat storage medium with respect to the basin, thus providing many combinations together with the numerous choices of PCM available. The selection of PCM should be done with reference to the water temperature and melting point of the PCM. In general, Paraffin with melting point less than $60^{\circ} \mathrm{C}$ was used as a PCM by most of the researchers and the best way to position the PCM is beneath the basin liner.

The greatest enhancement to solar still performance is obtained using multi-effect and active concepts. Two main bottlenecks to the output are the solar energy collection for evaporation and the dissipation of heat for condensation. Many types of solar energy collector can be used to enhance performance, including flat plate collectors, evacuated tubes, and solar ponds. Particularly promising among these is solar still with solar pond which enhances the productivity by about $80 \%$ over the conventional stills. Typically such active concepts require pumps and/or fans, which may use electricity, adding to expense and complexity.

\section{Scope for Future Research}

Based on the above review, the following future research directions are recommended: 
- Future research can be done in incorporating various nanoparticles with PCM beneath the basin to improve the yield rate, thermal properties, heat transfer characteristics and continuous production of fresh water even during the night.

- In a triangular solar still, some innovation in construction is needed to reduce the radiation loss of the glass.

- The development of software for the purpose of modelling and simulation in solar stills must be developed with respect to the various parameters discussed.

- Glass is used as the cover in most stills, but the maintenance of glass is troublesome. Further research can be done to replace the glass with alternative materials without loss of performance.

\section{Acknowledgements}

The authors gratefully acknowledge the Department of Science and Technology (Government of India) and British Council for providing financial support under the UKIERI Thematic Partnership (DST/INT/UK/P-86/2014).

\section{References}

[1] http://www.fewresources.org/water-scarcity-issues-were-running-out-of-water.html [accessed 12-Feb-16]

[2] Kabeel A E, S.A. El-Agouz. Review of researches and developments on solar stills. Desalination 2011; 276: 1-12.

[3] Bakkes J A. Background report to the OECD environmental Outlook to 2030: overviews, details, and methodology of model-based analysis. Netherlands Environmental Assessment Agency (MNP), 2008.

[4] Arnell N W. Climate change and global water resources: SRES emissions and socioeconomic scenarios. Global environmental change, 14(1), 31-52.

[5] Barker R, Dawe D, Tuong T. P, Bhuiyan S. I., \& Guerra L. C. (1999). The outlook for water resources in the year 2020: challenges for research on water management in rice production. Southeast Asia 1999; 1: 1-5.

[6] Lourdes García-Rodríguez. Assessment of most promising developments in solar desalination. Springer 2007; Solar Desalination for the 21st Century: 355-369.

[7] Kaushal A. Solar stills: A review. Renewable and Sustainable Energy Reviews 2010; 14(1): 446-453.

[8] Kalidasa Murugavel K, Chockalingam Kn K S K, Srithar K. Progresses in improving the effectiveness of the single basin passive solar still. Desalination 2008; 220: 677686.

[9] Prakash P \&Velmurugan. Parameters influencing the productivity of solar stills-A review. Renewable and Sustainable Energy Reviews 2015; 49: 585-609.

[10] Manokar A Muthu, KalidasaMurugavel, and G Esakkimuthu. Different parameters affecting the rate of evaporation and condensation on passive solar still-A review. Renewable and Sustainable Energy Reviews 2014; 38: 309-322.

[11] Sivakumar V, and E Ganapathy Sundaram. Improvement techniques of solar still efficiency: A review.Renewable and Sustainable Energy Reviews 2013; 28: 246264. 
[12] Velmurugan V \& Srithar K. Performance analysis of solar stills based on various factors affecting the productivity-A review. Renewable and Sustainable Energy Reviews 2011; 15(2): 1294-1304.

[13] Yadav S \& Sudhakar K. Different domestic designs of solar stills: A review. Renewable and Sustainable Energy Reviews 2015; 47: 718-731.

[14] Rajaseenivasan T, Murugavel K K, Elango T \& Hansen R. S. A review of different methods to enhance the productivity of the multi-effect solar still. Renewable and Sustainable Energy Reviews 2013: 17: 248-259.

[15] Sampathkumar K, Arjunan T V, Pitchandi P \& Senthilkumar P. Active solar distillation - a detailed review. Renewable and Sustainable Energy Reviews 2010; 4(6): 1503-1526.

[16] Xiao G, Wang X, Ni M, Wang F, Zhu W, Luo Z \& Cen K. A review on solar stills for brine desalination. Applied Energy 2013; 103: 642-652.

[17] Murugavel K K, Anburaj P, Hanson R S \& Elango T. Progresses in inclined type solar stills. Renewable and Sustainable Energy Reviews 2013; 20: 364-377.

[18] Manikandan V, Shanmugasundaram K, Janarthanan B \& Chandrasekaran J. (2013). Wick type solar stills: A review. Renewable and Sustainable Energy Reviews 2013; 20: 322-335.

[19] Elango C, N Gunasekaran and K Sampathkumar. Thermal models of solar still- A comprehensive review. Renewable and Sustainable Energy Reviews 2015; 47: 856-911.

[20] El-Sebaii A A. Effect of wind speed on active and passive solar stills. Energy Conversion and Management 2004; 45(7): 1187-1204.

[21] Ravishankar Sathyamurthy, Hyacinth J Kennady, Nagarajan P K, Amimul Ahsan. Factors affecting the performance of triangular pyramid solar still. Desalination 2014; 344: 383-390.

[22] Tiwari G N, Vimal Dimri, Arvind Chel. Parametric study of an active and passive solar distillation system: Energy and exergy analysis. Desalination 2009; 242: $1-$ 18.

[23] Tiwari G N, Shukla S K \& Singh I P. Computer modeling of passive/active solar stills by using inner glass temperature. Desalination 2003; 154(2): 171-185.

[24] Hossein Taghvaei, Hamed Taghvaei, Khosrow Jafarpur, Karimi Estahbanati M R, Mehrzad Feilizadeh,Mansoor Feilizadeh, Seddigh Ardekani A. A thorough investigation of the effects of water depth on the performance of active solar stills. Desalination 2014; 347: 77-85.

[25] Singh H N, Tiwari G N. Monthly performance of passive and active solar stills for different Indian climatic conditions. Desalination 2004; 168: 145-150.

[26] Tripathi R \& Tiwari G N. Thermal modeling of passive and active solar stills for different depths of water by using the concept of solar fraction. Solar Energy 2006; 80(8): 956-967.

[27] Panchal H N, Shah P K. Char Performance Analysis of Different Energy Absorbing Plates on Solar Stills. Iranica Journal of Energy \& Environment 2011; 4: 297-301.

[28] Anil Kr Tiwari and Tiwari G N. Annual performance analysis and thermal modelling of passive solar still for different inclinations of condensing cover. International Journal of Energy Research 2007; 31: 1358-1382. 
[29] Muhammad Ali Samee, Umar K Mirza, Tariq Majeed, Nasir Ahmad. Design and performance of a simple single basin solar still. Renewable and Sustainable Energy Reviews 2007; 11: 543-549.

[30] Rahul Dev, Tiwari G N. Characteristic equation of a passive solar still. Desalination 2009; 245: 246-265.

[31] Medugu D W, Ndatuwong L G. Theoretical analysis of water distillation using solar still. International Journal of Physical Sciences 2009; 4: 705-712.

[32] Feilizadeh M, Soltanieh M, Jafarpur K, Karimi Estahbanati M R. A new radiation model for a single-slope solar still. Desalination 2010; 262: 166-173.

[33] Zurigat Y H, Mousa K Abu-Arabi. Modeling and performance analysis of a solar desalination unit with double-glass cover cooling. Desalination 2001; 138: 145.

[34] Aboul-enei S, El-Sebaii A A, El-bialy E. Investigation of a single-basin solar still with deep basins. Renewable Energy 1998; 14: 299-305.

[35] Vinoth Kumar K, Kasturi Bai R. Performance study on solar still with enhanced condensation. Desalination 2008; 230: 51-61.

[36] Badran O O. Experimental study of the enhancement parameters on a single slope solar still productivity. Desalination 2007; 209:136-143.

[37] Rahbar N, Esfahani J A. Productivity estimation of a single-slope solar still: Theoretical and numerical analysis. Energy 2013; 49: 289-297.

[38] Narjes Setoodeh, Rahbar Rahimi, Abolhasan Ameri. Modelling and determination of heat transfer coefficient in a basin solar still using CFD. Desalination 2011; 268: $103-110$.

[39] Sivakumar V, Sundaram E G \& Sakthivel M. Investigation on the effects of heat capacity on the theoretical analysis of single slope passive solar still. Desalination and Water Treatment 2015; 1-13.

[40] Hiroshi Tanaka. Monthly optimum inclination of glass cover and external reflector of a basin type solar still with internal and external reflector. Solar Energy 2010; 84: 1959-1966.

[41] Hiroshi Tanaka. A theoretical analysis of basin type solar still with flat plate external bottom reflector. Desalination 2011; 279: 243-251.

[42] Boubekri M, Chaker A. Yield of an improved solar still: numerical approach. Energy Procedia 2011; 6: 610-617.

[43] Halimeh Aghaei Zoori, Farshad Farshchi Tabrizi, Faramarz Sarhaddi, Fazlollah Heshmatnezhad. Comparison between energy and exergy efficiencies in a weir type cascade solar still. Desalination 2013; 325: 113-121.

[44] Sadineni S B, Hurt R, Halford C K, Boehm R F. Theory and experimental investigation of a weir-type inclined solar still. Energy 2008; 33: 71-80.

[45] Nabil Hussain Rahim A. Utilization of a forced condensing technique in a moving film inclined solar desalination still. Desalination 1995; 101: 255-262.

[46] Hansen R S, Narayanan C S \& Murugavel K K. Performance analysis on inclined solar still with different new wick materials and wire mesh. Desalination 2015; 358: 1-8.

[47] Mahdi J T, Smith B E, Sharif A O. An experimental wick-type solar still system: Design and construction. Desalination 2011;267: 233-238. 
[48] El-Sebaii A A, Ramadan M R I, Aboul-Enein S \& El-Naggar M. Effect of fin configuration parameters on single basin solar still performance. Desalination $2015 ; 365: 15-24$.

[49] Velmurugan V, Gopalakrishnan M, Raghu R, Srithar K. Single basin solar still with fin for enhancing productivity. Energy Conversion and Management 2008; 49: 2602-2608.

[50] Velmurugan V, Deenadayalan C K, Vinod H, Srithar K. Desalination of effluent using fin type solar still. Energy 2008; 33: 1719-1727.

[51] Omara Z M, MofrehH Hamed, Kabeel A E. Performance of finned and corrugated absorbers solar stills under Egyptian conditions. Desalination 2011; 277: 281-287.

[52] Rahim N H A. New method to store heat energy in horizontal solar desalination still. Renewable Energy 2003; 28: 419-433.

[53] Velmurugan V, Naveen Kumar K J, Noorul Haq T, Srithar K. Performance analysis in stepped solar still for effluent desalination. Energy 2009; 34: 11791186.

[54] Salah Abdallah, Mazen M Abu-Khader, Omar Badran. Effect of various absorbing materials on the thermal performance of solar stills. Desalination 2009; 242:128137.

[55] Pankaj K Srivastava, Agrawal S K. Experimental and theoretical analysis of single sloped basin type solar still consisting of multiple low thermal inertia floating porous absorbers. Desalination 2013; 311: 198-205.

[56] Sakthivel S. Shanmugasundaram. Effect of energy storage medium (black granite gravel) on the performance of a solar still. International Journal of Energy Research 2008; 32: 68-82.

[57] Manivel R, D Dsilva Winfred Rufuss, S Sivakumar. Experimental Investigation of Solar Desalination System with Roof Heating. International Journal of Earth Science and Engineering 2013; 7(4): 1459-1464

[58] Dsilva Winfred Rufuss D, S Sivakumar. Enhancing the Performance by increasing the productivity of Water in Solar Desalination system with Roof Heating. International journal of Advanced Technology and Engineering Research 2014; 4:41-45.

[59] Kalidasa Murugavel K, Sivakumar S, RiazAhamed J, Chockalingam Kn K S K, Srithar K. Single basin double slope solar still with minimum basin depth and energy storing materials. Applied Energy 2010; 87: 514-523.

[60] Kalidasa Murugavel K, Srithar K. Performance study on basin type double slope solar still with different wick materials and minimum mass of water. Renewable Energy 2011; 36: 612-620.

[61] Kalidasa Murugavel K, Chockalingam Kn K S K, Srithar K. An experimental study on single basin double slope simulation solar still with thin layer of water in the basin. Desalination 2008; 220: 687-693.

[62] Omar Ansari, Mohamed Asbik, Abdallah Bah, Abdelaziz Arbaoui, Ahmed Khmou. Desalination of the brackish water using a passive solar still with a heat energy storage system. Desalination 2013; 324: 10-20.

[63] Abdulhaiy M. Radhwan. Transient performance of a stepped solar still with built-in latent heat thermal energy storage. Desalination 2004; 171: 61-76. 
[64] El-Sebaii A A, Al-Ghamdi A A, Al-Hazmi F S, Adel S Faidah. Thermal performance of a single basin solar still with PCM as a storage medium. Applied Energy 2009; 86: 1187-1195.

[65] Mohammad Dashtban, Farshad Farshchi Tabrizi. Thermal analysis of a weir-type cascade solar still integrated with PCM storage. Desalination 2011; 279: 415-422.

[66] Swetha K, Venugopal J. Experimental investigation of a single slope solar still using PCM. International Journal of Research in Environmental Science and Technology 2011; 1: 30-33.M.

[67] Badran O. Theoretical analysis of solar distillation using active solar still. International Journal of Thermal \& Environmental Engineering 2011; 3: 113120.

[68] Su W, Darkwa J \& Kokogiannakis G. Review of solid-liquid phase change materials and their encapsulation technologies. Renewable and Sustainable Energy Reviews 2015; 48: 373-391.

[69] Eduardo Rubio-Cerda, Miguel A. Porta-Ga'ndara, Jose'L. Ferna'ndez-Zayas. Thermal performance of the condensing covers in a triangular solar still. Renewable Energy 2002; 27: 301-308.

[70] Fatha H E S, El-Samanoudy M, Fahmy K, Hassabou A. Thermal-economic analysis and comparison between pyramid-shaped and single-slope solar still configurations. Desalination 2003; 159: 69-79.

[71] Ali Kianifar, Saeed Zeinali Heris, Omid Mahian. Exergy and economic analysis of a pyramid-shaped solar water purification system: Active and passive cases. Energy 2012; 38: 31-36.

[72] Ahsan A, Imteaz M, Thomas U A, Azmi M, Rahman A, Nik Daud N.N. Parameters affecting the performance of a low cost solar still. Applied Energy 2014; 114: 924 930.

[73] Jamal, Wasil, M Altamush Siddiqui. Effect of water depth and still orientation on productivity for passive solar distillation. Int J Eng Res Appl 2014; 2: 1659-1665.

[74] Arunkumar T, Jayaprakash R, Prakash A, Suneesh P U, Karthik M, Sanjay Kumar. Study of thermo physical properties and an improvement in production of distillate yield in pyramid solar still with boosting mirror. Indian Journal of Science and Technology 2010; 8: 879-884.

[75] Amimul Ahsan, Teruyuki Fukuhara. Mass and heat transfer model of Tubular Solar Still. Solar Energy 2010; 84: 1147-1156.

[76] Zhili Chen, Yang Yao, Zihang Zheng, Hongfei Zheng, Yi Yang, Li'an Hou, Guanyi Chen. Analysis of the characteristics of heat and mass transfer of a three-effect tubular solar still and experimental research. Desalination 2013; 330: 42-48.

[77] Rahbar N, Esfahani J A \& Fotouhi-Bafghi E. Estimation of convective heat transfer coefficient and water-productivity in a tubular solar still-CFD simulation and theoretical analysis. Solar Energy 2015; 113: 313-323.

[78] Ahsan A \&Fukuhara T. Evaporability and Productivity of a New Tubular Solar Still. In Advances in Water Resources and Hydraulic Engineering 2009; 333-338. Springer Berlin Heidelberg.

[79] Amimul Ahsan, Monzur Imteaz, Ataur Rahman, Badronnisa Yusuf, Fukuhara T. Design, fabrication and performance analysis of an improved solar still. Desalination 2012; 292: 105-112. 
[80] Arunkumar T, Jayaprakash R, Denkenberger D, Amimul Ahsan, Okundamiya M S, Sanjay kumar, Hiroshi Tanaka, Aybar H.S. An experimental study on a hemispherical solar still. Desalination 2012; 286: 342-348.

[81] Basel I Ismail. Design and performance of a transportable hemispherical solar still. Renewable Energy 2009; 34: 145-150.

[82] Al-Hinai H, Al-Nassri M S, Jubran B A. Effect of climatic, design and operational parameters on the yield of a simple solar still. Energy Conversion and Management 2002; 43: 1639-1650.

[83] Rahul Dev, Singh H N, Tiwari G N. Characteristic equation of double slope passive solar still. Desalination 2011; 267: 261-266.

[84] Hanane Aburideh, Adel Deliou, Brahim Abbad, Fatma Alaoui, Djilali Tassalit, Zahia Tigrine. An Experimental Study of a Solar Still: Application on the sea water desalination of Fouka. Procedia Engineering 2012; 33: 475 - 484.

[85] Kalidasa Murugavel K, Chockalingam Kn K S K, Srithar K. An experimental study on single basin double slope simulation solar still with thin layer of water in the basin. Desalination 2008; 220: 687-693.

[86] Rajamanickam M R, Ragupathy A. Influence of Water Depth on Internal Heat and Mass Transfer in a Double Slope Solar Still. Energy Procedia 2012; 14: 1701 1708.

[87] Trad Abderachid, Kaabi Abdenacer. Effect of orientation on the performance of a symmetric solar still with a double effect solar still (comparison study). Desalination 2013; 329: 68-77.

[88] Minasian A N, Al-Karaghouli A.A. Floating vertical solar still for desalination of marsh water. Renewable Energy 1992; 2: 631-635.

[89] Boukar M, Harmim A. Parametric study of a vertical solar still under desert climatic conditions. Desalination 2004; 168: 21-28.

[90] Hiroshi Tanaka. Experimental study of vertical multiple-effect diffusion solar still coupled with a flat plate reflector. Desalination 2009; 249: 34-40.

[91] Boukar M, Harmim A. Development and testing of a vertical solar still. Desalination 2003; 158: 179.

[92] Boukar M \& Harmim A. Performance evaluation of a one-sided vertical solar still tested in the desert of Algeria. Desalination 2005; 183(1): 113-126.

[93] Tanaka H \& Nakatake Y. A simple and highly productive solar still: a vertical multiple-effect diffusion-type solar still coupled with a flat-plate mirror. Desalination 2005; 173(3): 287-300.

[94] El-Sebaii A A. Parametric study of a vertical solar still. Energy conversion and Management 1998; 39(13): 1303-1315.

[95] Sodha, M S Kumar A, Tiwari G N \& Tyagi R C. Simple multiple wick solar still: analysis and performance. Solar energy 1981; 26(2): 127-131.

[96] Sangeeta Suneja, Tiwari G N. Optimization of number of effects for higher yield from an inverted absorber solar still using the Runge-Kutta method. Desalination 1998; 120: 197-209.

[97] Tanaka H, Nosoko T, Nagata T. Experimental study of basin-type, multiple-effect, diffusion-coupled solar still. Desalination 2002; 150: 131-144.

[98] Hiroshi Tanaka. Tilted wick solar still with flat plate bottom reflector. Desalination 2011; 273: 405-413. 
[99] Hilal Al-Hinai, Al-Nassri M S, Jubran B A. Parametric investigation of a double effect solar still in comparison with a single-effect solar still. Desalination 2002; 150: 75-83.

[100] El-Sebaii A A. Effect of wind speed on active and passive solar stills. Energy Conversion and Management 2004; 45(7): 1187-1204.

[101] E1-Sebaii A A. Thermal performance of triple basin solar still. Desalination 2005; 170:23-37.

[102] Cappelletti G M. An Experiment with plastic solar still. Desalination 2002; 142:221-227.

[103] Phadatare M K, Veema S K. Influence of water depth on internal heat and mass transfer in plastic solar still. Desalination 2007; 217:267-275.

[104] Madhlopa A, Johnstone C. Numerical study of a passive solar still with separate condenser. Renewable Energy 2009; 34: 1668-1677.

[105] Farhad Nematollahi, Amir Rahimi, Touraj Tavakoli Gheinani. Experimental and theoretical energy and exergy analysis for a solar desalination system. Desalination 2013; 317: 23-31.

[106] Vimal Dimri, Bikash Sarkar, Usha Singh, G N Tiwari. Effect of condensing cover material on yield of an active solar still: an experimental validation. Desalination 2008; 227: 178-189.

[107] Tiwari G N, Sandy Kumar, Sharma P B, Emran Khan M. Instantaneous thermal efficiency of an active solar still. Applied Thermal Engineering 1996; 16: 189-192.

[108] Arslan M. Experimental investigation of still performance for different active solar still designs under closed cycle mode. Desalination 2012; 307: 9-19.

[109] Rajaseenivasan T, Nelson Raja P, Srithar K. An experimental investigation on a solar still with an integrated flat plate collector. Desalination 2014; 347: 131-137.

[110] Kabeel A E, Khalil A, Omara Z M, Younes M M. Theoretical and experimental parametric study of modified stepped solar still. Desalination 2012; 289: 12-20.

[111] Badran O O. Experimental study of the enhancement parameters on a single slope solar still productivity. Desalination 2007; 209:136-143.

[112] Hossein Taghvaei, Hamed Taghvaei, Khosrow Jafarpur, Karimi Estahbanati M.R, Mehrzad Feilizadeh, Mansoor Feilizadeh, Seddigh Ardekani A. A thorough investigation of the effects of water depth on the performance of active solar stills. Desalination 2014; 347: 77-85.

[113] Mohamed A Eltawil, Omara Z M. Enhancing the solar still performance using solar photovoltaic, flat plate collector and hot air. Desalination 2014; 349: 1-9.

[114] Shiv Kumar, Tiwari G N. Life cycle cost analysis of single slope hybrid (PV/T) active solar still. Applied Energy 2009; 86: 1995-2004.

[115] Salah Abdallah, Omar Badran, Mazen M Abu-Khader. Performance evaluation of a modified design of a single slope solar still. Desalination 2008; 219: 222-230.

[116] Shiv Kumar, Aseem Dubey, Tiwari G N. A solar still augmented with an evacuated tube collector in forced mode. Desalination 2014; 347: 15-24.

[117] Eugenio Garc1a Marı, Rosa Penelope Gutierrez Colomer, Carlos Adrados, BlaiseOmbrecht. Performance analysis of a solar still integrated in a greenhouse. Desalination 2007; 203: 435-443.

[118] Velmurugan V, Srithar K. Solar stills integrated with a mini solar pond. Analytical simulation and experimental validation. Desalination 2007; 216: 232-241. 
[119] Velmurugan V, Pandiarajan S, Guruparan P, Subramanian L H, Prabaharan C D \& Srithar K. Integrated performance of stepped and single basin solar stills with mini solar pond. Desalination 2009; 249(3): 902-909.

[120] Velmurugan V, Mandlin J, Stalin B \& Srithar K. Augmentation of saline streams in solar stills integrating with a mini solar pond. Desalination 2009; 249(1): 143-149.

[121] El-Sebaii A A, Aboul-Enein S, Ramadan M R I, Khallaf A M. Thermal performance of an active single basin solar still (ASBS) coupled to shallow solar pond (SSP). Desalination 2011; 280: 183-190.

[122] Javad Abolfazli Esfahani, Nader Rahbar, Mehdi Lavvaf. Utilization of thermoelectric cooling in a portable active solar still. An experimental study on winter days. Desalination 2011; 269: 198-205.

[123] Zeinab Abdel-Rehim S, Ashraf Lasheen. Experimental and theoretical study of a solar desalination system located in Cairo, Egypt. Desalination 2007; 217: 52-64.

[124] Gorjian S, Ghobadian B, Hashjin T T \& Banakar, A. Experimental performance evaluation of a stand-alone point-focus parabolic solar still. Desalination 2014; 352: 1-17.

[125] Arunkumar T, Denkenberger D, Amimul Ahsan, Jayaprakash R. The augmentation of distillate yield by using concentrator coupled solar still with phase change material. Desalination 2013; 314: 189-192.

[126] Arunkumar T, Vinothkumar K, Amimul Ahsan, Jayaprakash R, Sanjay Kumar. Experimental Study on a Compound Parabolic Concentrator Tubular Solar Still Tied with Pyramid Solar Still. Advancing Desalination INTCH open science 2011; 9: 183-194.

[127] Farshad Farshchi Tabrizi, Ashkan Zolfaghari Sharak. Experimental study of an integrated basin solar still with a sandy heat reservoir. Desalination 2010; 253: 195-199.

[128] Sampathkumar K, Senthilkumar P. Utilization of solar water heater in a single basin solar still—an experimental study. Desalination 2012; 297: 8-19.

[129] Abdullah A.S. Improving the performance of stepped solar still. Desalination 2013; 319: 60-65.

[130] El-Zahaby A M, Kabeel A E, Bakry A I, El-Agouz S A, Hawam O M. Enhancement of solar still performance using a reciprocating spray feeding system — an experimental approach. Desalination 2011; 267: 209-216.

[131] Nabil Hussain A Rahim. Utilisation of new technique to improve the efficiency of horizontal solar desalination still. Desalination 2011; 138: 121-128.

[132] ST Ahmed. Study of single-effect solar still with an internal condenser, Solar and Wind Technology 1988; 5: 637-643.

[133] Belhadj M M, Bouguettaia H, Marif Y \&Zerrouki M. Numerical study of a doubleslope solar still coupled with capillary film condenser in south Algeria. Energy Conversion and Management 2015; 94: 245-252.

[134] Hassan E S Fath, Hosny H M. Thermal performance of a single-sloped basin still with an inherent built-in additional condenser. Desalination 2002; 142:1927.

[135] Kabeel A E, Omara Z M, Essa F A. Enhancement of modified solar still integrated with external condenser using Nanofluids: An experimental approach. Energy Conversion and Management 2014; 78: 493-498. 
[136] Mousa Abu-Arabi, Yousef Zurigat. Year-round comparative study of three types of solar desalination units. Desalination 2005; 172: 137-143.

[137] Sakthivel M, Shanmugasundaram S, Alwarsamy T. An experimental study on regenerative solar still with energy storage medium-Jute cloth. Desalination 2010; 264: 24-31.

[138] Prakash J, Kavathekar A K. Performance prediction of regenerative solar still. Solar and wind technology 1986; 3: 119-125.

[139] Sanjay Kumar, Sinha S. Transient model and comparative study of concentrator coupled regenerative solar still in forced circulation mode. Energy conversion and management 1996; 37: 629-636.

[140] Singh A K, Tiwari G N. Thermal evaluation of regenerative active solar distillation under thermosyphon mode. Energy conversion and management 1993; 34: 697706.

[141] Sinha S, Sanjay Kumar. Theoretical evaluation of air regenerative solar distiller integrated with aspirator. Renewable energy 1994; 4: 311-318.

[142] Zeinab S, Abdel-Rehim, Ashraf Lasheen. Improving the performance of solar desalination systems. Renewable Energy 2005; 30: 1955-1971.

[143] Mohamed A Eltawil, Zhao Zhengming. Wind turbine-inclined still collector integration with solar still for brackish water desalination. Desalination 2009; 249: 490-497.

[144] Lu Zuo, Yuan Zheng, Zhenjie Li, YujunSha. Solar chimneys integrated with sea water desalination. Desalination 2011; 276: 207-213.

[145] Hichem Marmouch, Jamel Orfi, Sassi Ben Nasrallah. Effect of a cooling tower on a solar desalination system. Desalination 2009; 238: 281-289.

[146] Khaled M S Eldalil. Improving the performance of solar still using vibratory harmonic effect. Desalination 2010; 251: 3-11.

[147] Shiv Kumar and Arvind Tiwari. An experimental study of hybrid photovoltaic thermal (PV/T)-active solar still. . International Journal of Energy Research 2008; 32: 847-858.

[148] Rahul Dev, Tiwari G N. Characteristic equation of a hybrid (PV-T) active solar still. Desalination 2010; 254: 126-137.

[149] Gajendra Singh, Shiv Kumar, Tiwari G N. Design, fabrication and performance evaluation of a hybrid photovoltaic thermal (PVT) double slope active solar still. Desalination 2011; 277: 399-406.

[150] Hassan E S Fath, Hosny H M.Thermal performance of a single-sloped basin still with an inherent built-in additional condenser. Desalination 2002; 142:1927.

[151] Elango T \& Murugavel K K. The effect of the water depth on the productivity for single and double basin double slope glass solar stills. Desalination 2015; 359: 8291.

[152] Panchal H N. Enhancement of distillate output of double basin solar still with vacuum tubes. Journal of King Saud University-Engineering Sciences 2013.

[153] Nishikawa H, Tsuchiya T, Narasaki Y, Kamiya I, Sato H. Triple effect evacuated solar still system for getting fresh water from seawater. Applied Thermal Engineering 1998; 18: 1067-1075. 
[154] Ahmed M I, Hrairi M, Ismail A F. On the characteristics of multistage evacuated solar distillation. Renewable Energy 2009; 34: 1471-1478.

[155] Reddy K S, Ravi Kumar K, Tadhg S O'Donovan, Mallick T K. Performance analysis of an evacuated multi-stage solar water desalination system. Desalination 2012; 288: 80-92.

[156] Sanjeev Kumar and G N Tiwari. Triple basin active solar still. International Journal of Energy Research 1999; 23: 529-542.

[157] Mahkamov Kh, Akhatov J.S. Experimental study of the performance of multieffect solar thermal water desalination system. Applied Solar Energy 2008; 44: 31 34.

[158] Al Baharna N S, Aj Mahdi N, Zaky F. Performance Analysis of triple basin still integrated with natural circulation solar heater. Energy conversion and Management 1993; 34: 545-556.

[159] Elsafty A F, Fath H E, Amer A M. Mathematical model development for a new solar desalination system (SDS). Energy Conversion and Management 2008; 49: 3331-3337.

[160] Okujagu C U, Osarolube E, Abia S C. Single effect green house type solar still for portable water supply. Scientia Africana 2008; 7: 111-122.

[161] Eugenio Garcia Marı, Rosa Penelope Gutierrez Colomer, Carlos Adrados, BlaiseOmbrecht. Performance analysis of a solar still integrated in a greenhouse. Desalination 2007; 203: 435-443.

[162] Chaibi M T. Analysis by simulation of a solar still integrated in a greenhouse roof. Desalination 2000; 128(2): 123-138.

[163] Voropoulos K, Mathioulakis E \& Belessiotis V. Transport phenomena and dynamic modeling in greenhouse-type solar stills. Desalination 2000; 129(3): 273281.

[164] Voropoulos K, Mathioulakis E, Belessiotis V. A hybrid solar desalination and water heating system. Desalination 2004; 164: 189-195.

[165] Silakhori M, Naghavi M S, Metselaar H S C, Mahlia T M I, Fauzi H \&Mehrali M. Accelerated thermal cycling test of microencapsulated paraffin wax/polyaniline made by simple preparation method for solar thermal energy storage. Materials 2013; 6(5): 1608-1620.

[166] Su W, Darkwa J \& Kokogiannakis G. Review of solid-liquid phase change materials and their encapsulation technologies. Renewable and Sustainable Energy Reviews 2015; 48: 373-391.

[167] Kenisarin M \& Mahkamov K. Solar energy storage using phase change materials. Renewable and Sustainable Energy Reviews 2007; 11(9): 1913-1965.

[168] Zaib Q \& Fath H. Application of carbon Nano-materials in desalination processes. Desalination and Water Treatment 2013; 51(1-3): 627-636.

[169] Gehrke I, Geiser A \& Somborn-Schulz A. Innovations in Nanotechnology for water treatment. Nanotechnology, science and applications 2015;8: 1.

[170] Nasreen S A A N, Sundarrajan S, Nizar S A S, Balamurugan R \& Ramakrishna S. Advancement in electrospunNanofibrous membranes modification and their application in water treatment. Membranes 2013; 3(4): 266-284.

[171] Sekhon B. S. Nanotechnology in agri-food production: an overview.Nanotechnology, science and applications 2014; 7: 31. 
[172] Shen Y, Zhou Y, Chen S, Yang F, Zheng S \& Hou H. Carbon Nanofibers Modified Graphite Felt for High Performance Anode in High Substrate Concentration Microbial Fuel Cells. The Scientific World Journal, 2014.

[173] Fang J, Levchenko I, Han Z J, Yick S \& Ostrikov K K. Carbon Nanotubes on Nanoporous alumina: from surface mats to conformal pore filling. Nanoscale research letters 2014; 9(1): 1-8.

[174] Wang Y, Xia T D, Feng H X \& Zhang H. Stearic acid/Polymethylmethacrylate composite as form-stable phase change materials for latent heat thermal energy storage. Renewable Energy 2011; 36(6): 1814-1820.

[175] Weislogel M M. \& Chung J N. Experimental investigation of condensation heat transfer in small arrays of PCM-filled spheres. International journal of heat and mass transfer 1991; 34(1): 31-45.

[176] Murshed S M S, Leong, K C \& Yang C. Enhanced thermal conductivity of $\mathrm{TiO}_{2}$ water based Nanofluids. International Journal of Thermal Sciences 2005;44(4): 367-373.

[177] Harikrishnan S \& Kalaiselvam S. Preparation and thermal characteristics of CuOoleic acid Nanofluids as a phase change material. ThermochimicaActa 2012,533, 46-55.

[178] Kalaiselvam S, Parameshwaran R \& Harikrishnan S. Analytical and experimental investigations of Nanoparticles embedded phase change materials for cooling application in modern buildings. Renewable Energy 2012; 39(1): 375-387.

[179] Fan L W, Fang X, Wang X, Zeng Y, Xiao Y Q, Yu Z T \& Cen K F. Effects of various carbon Nanofillers on the thermal conductivity and energy storage properties of paraffin-based Nanocomposite phase change materials. Applied Energy 2013; 110: 163-172.

[180] Parameshwaran R, Jayavel R \& Kalaiselvam S. Study on thermal properties of organic ester phase-change material embedded with silver Nanoparticles. Journal of thermal analysis and calorimetry 2013; 114(2): 845-858.

[181] Song Q, Li Y, Xing J, Hu J Y \& Marcus Y. Thermal stability of composite phase change material microcapsules incorporated with silver Nano-particles. Polymer 2007; 48(11): 3317-3323.

[182] Han P, Zheng X H, Hou W S, Qiu L \& Tang D W. Study on heat-storage and release characteristics of multi-cavity-structured phase-change microcapsules. Phase Transitions 2015; 88(7): 704-715.

[183] Yang Y, Luo J, Song G, Liu Y \& Tang G. The experimental exploration of Nano$\mathrm{Si} 3 \mathrm{~N}$ 4/paraffin on thermal behaviour of phase change materials. ThermochimicaActa 2014; 597: 101-106.

[184] Zheng F, Yang C, Ji X, Hu D, Chen Y \& Liu M. Surfactants assisted synthesis and electrochemical properties of Nano-LiFePO 4/C cathode materials for low temperature applications. Journal of Power Sources 2015; 288: 337-344.

[185] Shabani-Shayeh J, Ehsani A, Ganjali M R, Norouzi P \& Jaleh B. Conductive polymer/reduced graphene oxide/ $\mathrm{Au}$ Nano particles as efficient composite materials in electrochemical supercapacitors. Applied Surface Science 2015; 353: 594-599. 
[186] Fang Y, Yu H, Wan W, Gao X \& Zhang Z. Preparation and thermal performance of polystyrene/n-tetradecane composite Nanoencapsulated cold energy storage phase change materials. Energy Conversion and Management 2013; 76: 430-436.

[187] Sarı A, Alkan C, Döğüşcü D K \& Kızıl Ç. Micro/Nano encapsulated n-tetracosane and n-octadecane eutectic mixture with polystyrene shell for low-temperature latent heat thermal energy storage applications. Solar Energy 2015; 115: 195-203.

[188] Park S H. Decay rate estimates for a weak viscoelastic beam equation with timevarying delay. Applied Mathematics Letters 2014; 31: 46-51.

[189] Halawa E \& Saman W. Thermal performance analysis of a phase change thermal storage unit for space heating. Renewable Energy 2011; 36(1): 259-264.

[190] Mehrali M, Latibari S T, Mehrali M, Metselaar H S C \& Silakhori M Shapestabilized phase change materials with high thermal conductivity based on paraffin/graphene oxide composite. Energy Conversion and Management 2013; 67: 275-282.

[191] Wang W, Wang C, Wang T, Li W, Chen L, Zou R \& Li X. Enhancing the thermal conductivity of n-eicosane/silica phase change materials by reduced graphene oxide. Materials Chemistry and Physics 2014; 147(3): 701-706.

[192] Mehrali M, Latibari S T, Mehrali M, Mahlia T M I \& Metselaar H S C. Preparation and properties of highly conductive palmitic acid/graphene oxide composites as thermal energy storage materials. Energy 2013; 58: 628-634.

[193] Hong T K, Yang H S \& Choi C J. Study of the enhanced thermal conductivity of Fe Nanofluids. Journal of Applied Physics 2005; 97(6): 064311.

[194] Sarı A \& Karaipekli A. Thermal conductivity and latent heat thermal energy storage characteristics of paraffin/expanded graphite composite as phase change material. Applied Thermal Engineering 2007; 27(8): 1271-1277.

[195] Zhao C Y, Lu W \& Tian Y. Heat transfer enhancement for thermal energy storage using metal foams embedded within phase change materials (PCMs). Solar Energy 2010; 84(8): 1402-1412.

[196] Mettawee E B S \& Assassa G M. Thermal conductivity enhancement in a latent heat storage system. Solar Energy 2007; 81(7): 839-845.

[197] Rao Z H, Wang S H, Zhang Y L, Zhang G Q \& Zhang J Y. Thermal Properties of Paraffin/Nano-AlN Phase Change Energy Storage Materials. Energy Sources, Part A: Recovery, Utilization, and Environmental Effects 2014; 36(20): 2281-2286.

[198] Zaib Q \& Fath H. Application of carbon Nano-materials in desalination processes. Desalination and Water Treatment 2013; 51(1-3): 627-636.

[199] LLNL licenses carbon Nano-tube technology for desalination to Porifera. Membrane Technology 2010; 2: 16.

[200] Yi X S, Yu S L, Shi W X, Wang S, Sun N, Jin L M \& Ma C. Estimation of fouling stages in separation of oil/water emulsion using Nano-particles Al 2 O 3/TiO 2 modified PVDF UF membranes. Desalination 2013; 319: 38-46.

[201] Essalhi M \& Khayet M. Fabrication and Characterization of Electro-Spun NanoFibrous Membranes for Desalination by Membrane Distillation. Procedia Engineering 2012; 44: 235-237.

[202] Hosseini S M, Madaeni S S \& Khodabakhshi A R. Preparation and characterization of PC/SBR heterogeneous cation exchange membrane filled with carbon Nanotubes. Journal of Membrane Science 2010; 362(1): 550-559. 
[203] Goh P S, Ismail A F \& Hilal N. Nano-enabled membranes technology: Sustainable and revolutionary solutions for membrane desalination. Desalination 2015: Accepted in Press

[204] Hong J \& He Y. Polyvinylidene fluoride ultrafiltration membrane blended with Nano-ZnO particle for photo-catalysis self-cleaning. Desalination 2014: 332(1): $67-75$.

[205] Rajaseenivasan T, and K Srithar. Performance investigation on solar still with circular and square fins in basin with $\mathrm{CO} 2$ mitigation and economic analysis. Desalination 380 (2016): 66-74.

[206] Arunkumar T, R Velraj, D C Denkenberger, Ravishankar Sathyamurthy, K Vinoth Kumar, and Amimul Ahsan. Productivity enhancements of compound parabolic concentrator tubular solar stills. Renewable Energy 88 (2016): 391-400.

[207] Ibrahim, Ayman G M, Elsayed E Allam, and Salman E Elshamarka. A modified basin type solar still: Experimental performance and economic study. Energy 93 (2015): 335-342.

[208] D G Harris Samuel, P K Nagarajan, Ravishankar Sathyamurthy, S A El-Agouz, E Kannan. Improving the yield of fresh water in conventional solar still using low cost energy storage material. Energy Conversion and Management 112 (2016) $125-134$

[209] Ayoub, George M, and Lilian Malaeb. Economic feasibility of a solar still desalination system with enhanced productivity. Desalination 335, no. 1 (2014): 27-32.

[210] Sharon H, and K S Reddy. Performance investigation and enviro-economic analysis of active vertical solar distillation units. Energy 84 (2015): 794-807. 


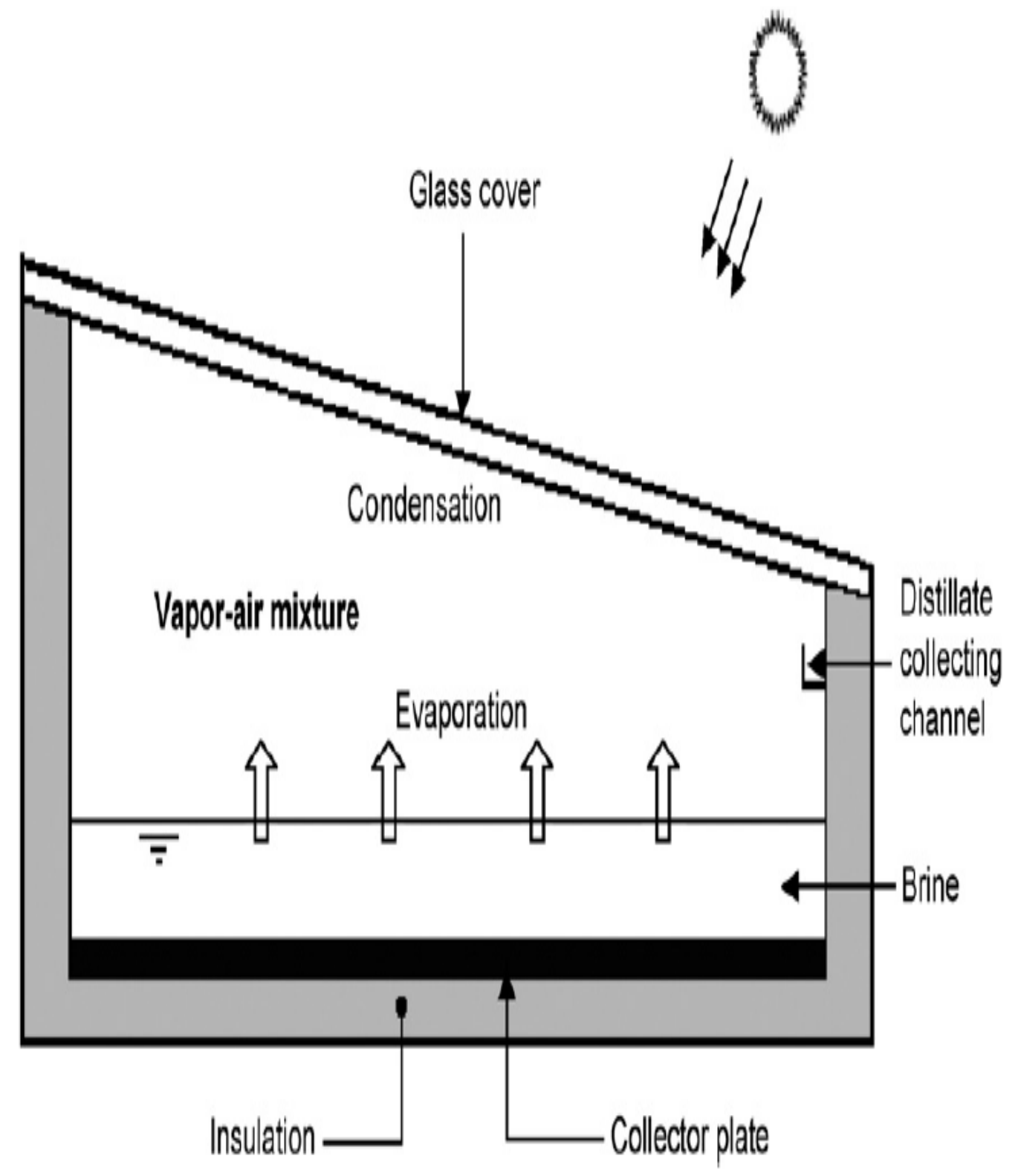

Fig.1 Schematic diagram of single basin single slope solar still [30] 


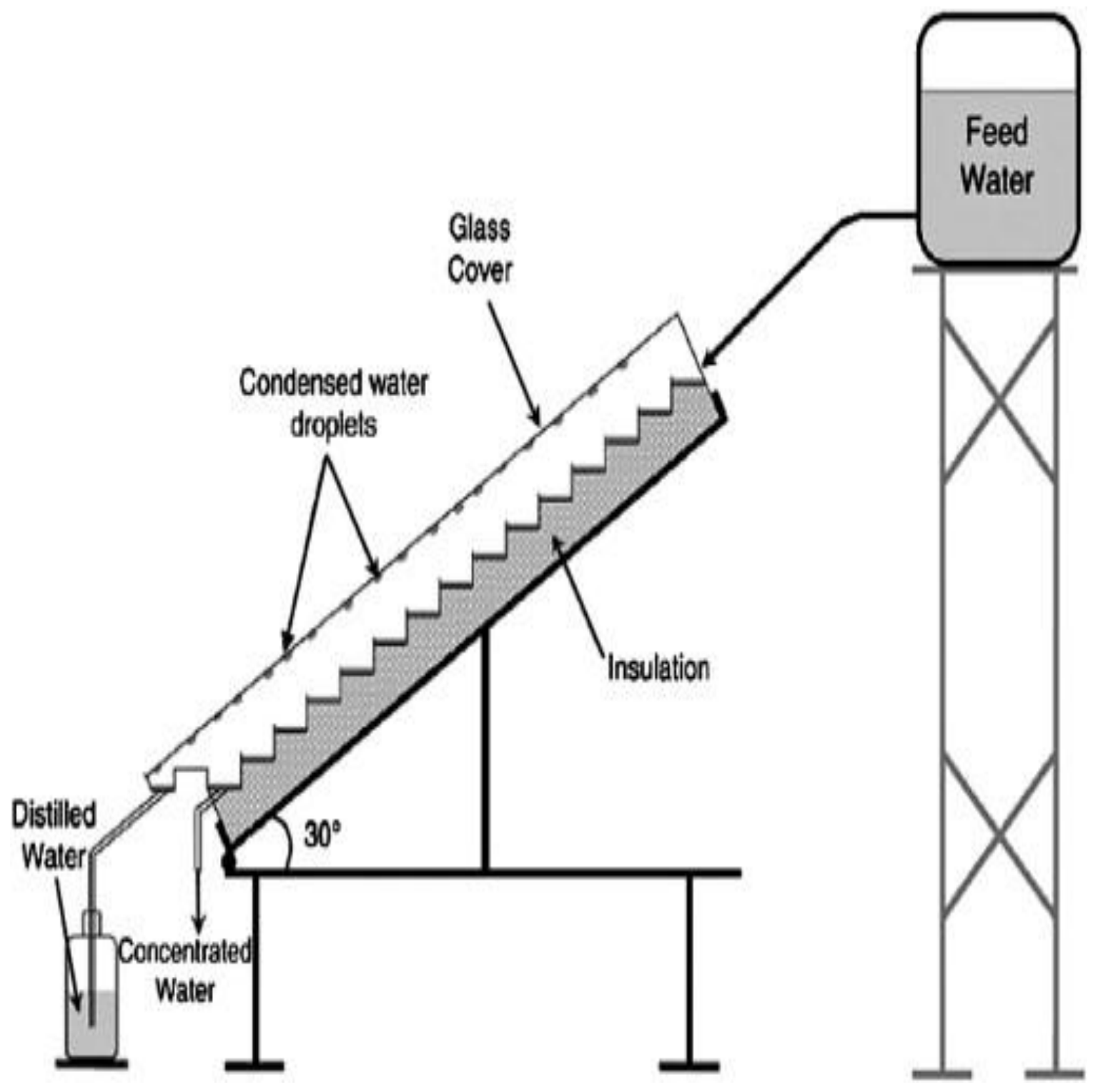

Fig.2 Schematic diagram of single basin single slope stepped solar still [45] 


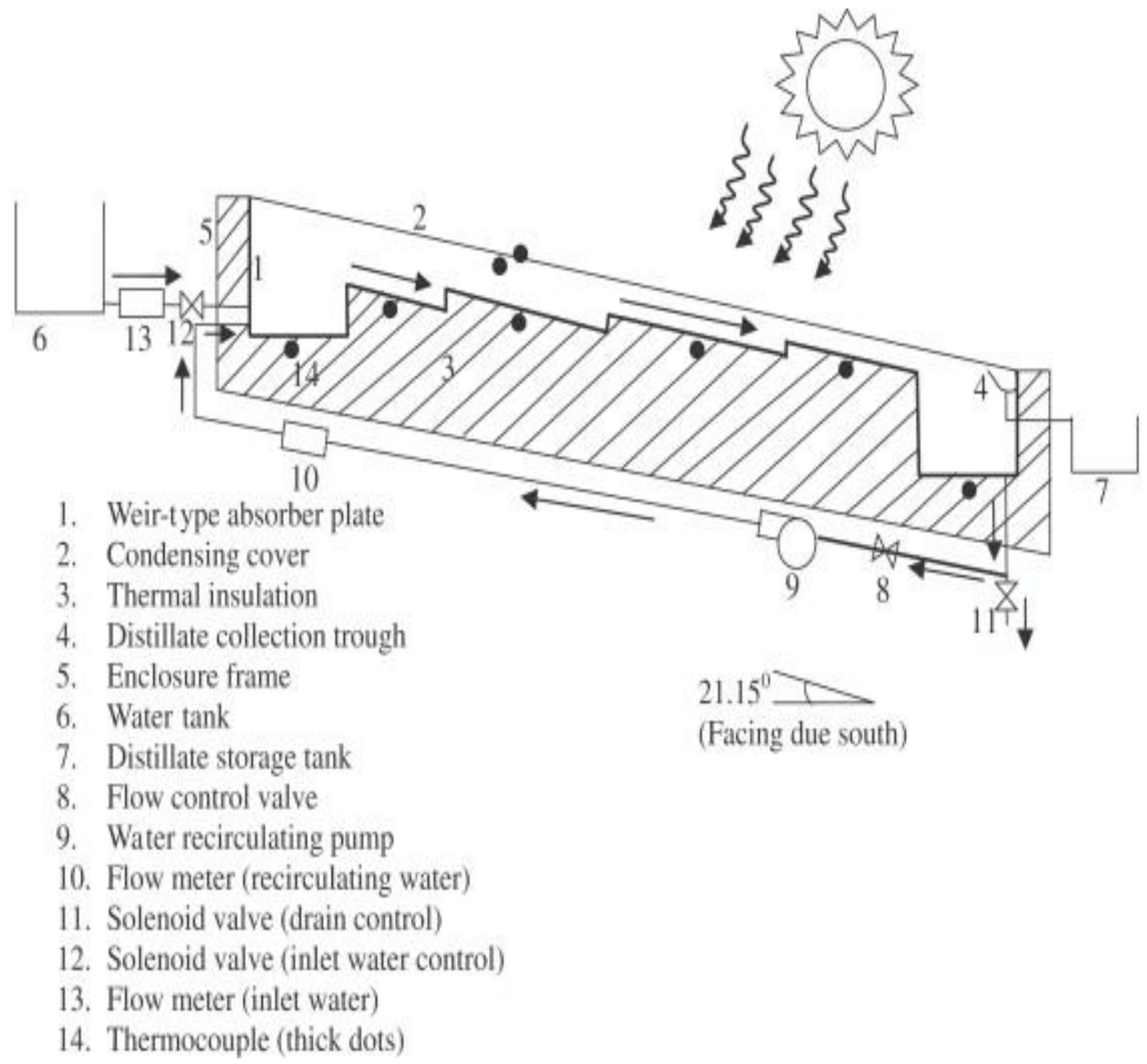

Fig.3 Schematic diagram of single basin single slope stepped solar still with weir type absorber [43] 


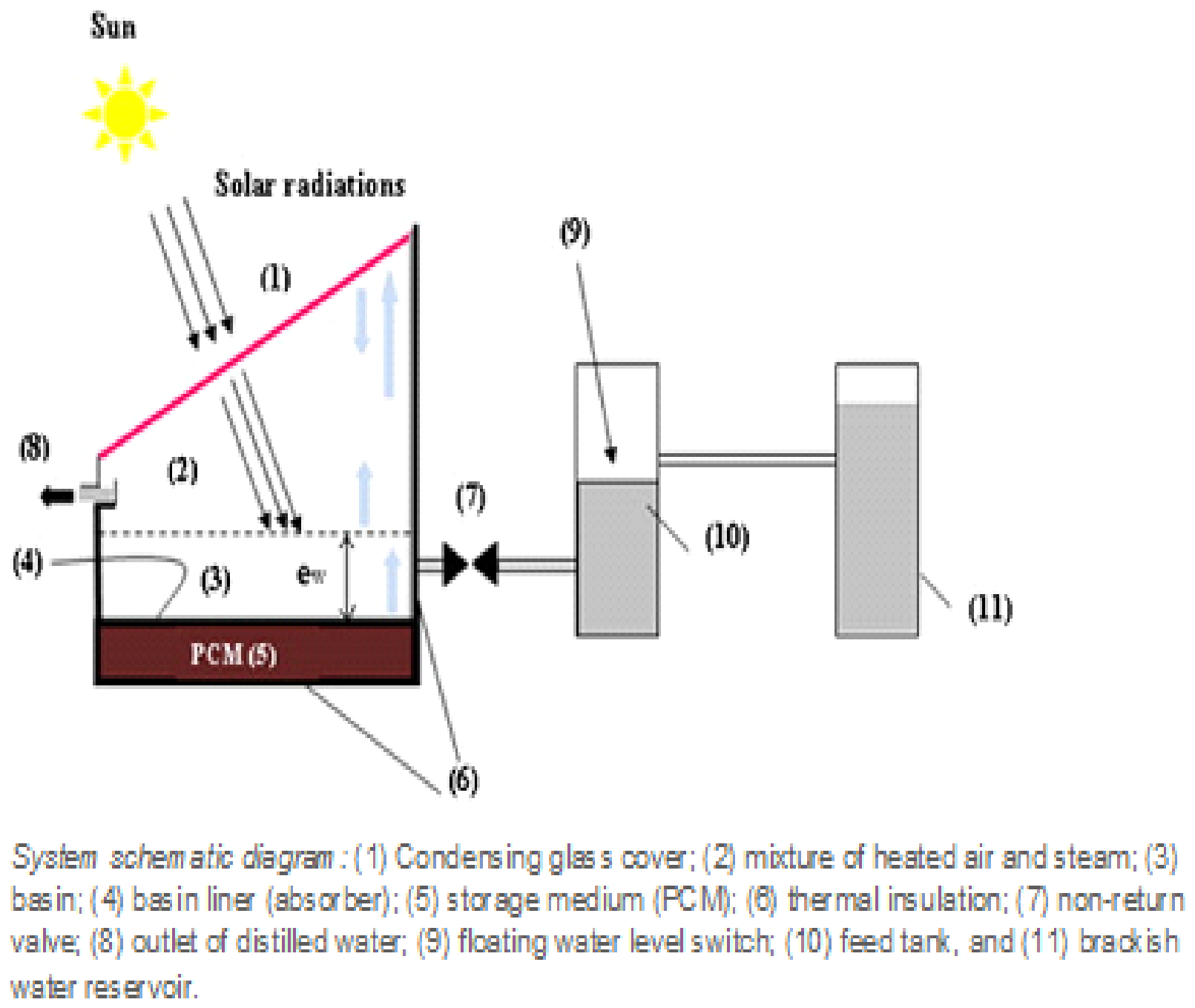

Fig.4 Schematic diagram of single basin single slope solar still with phase change material [62] 


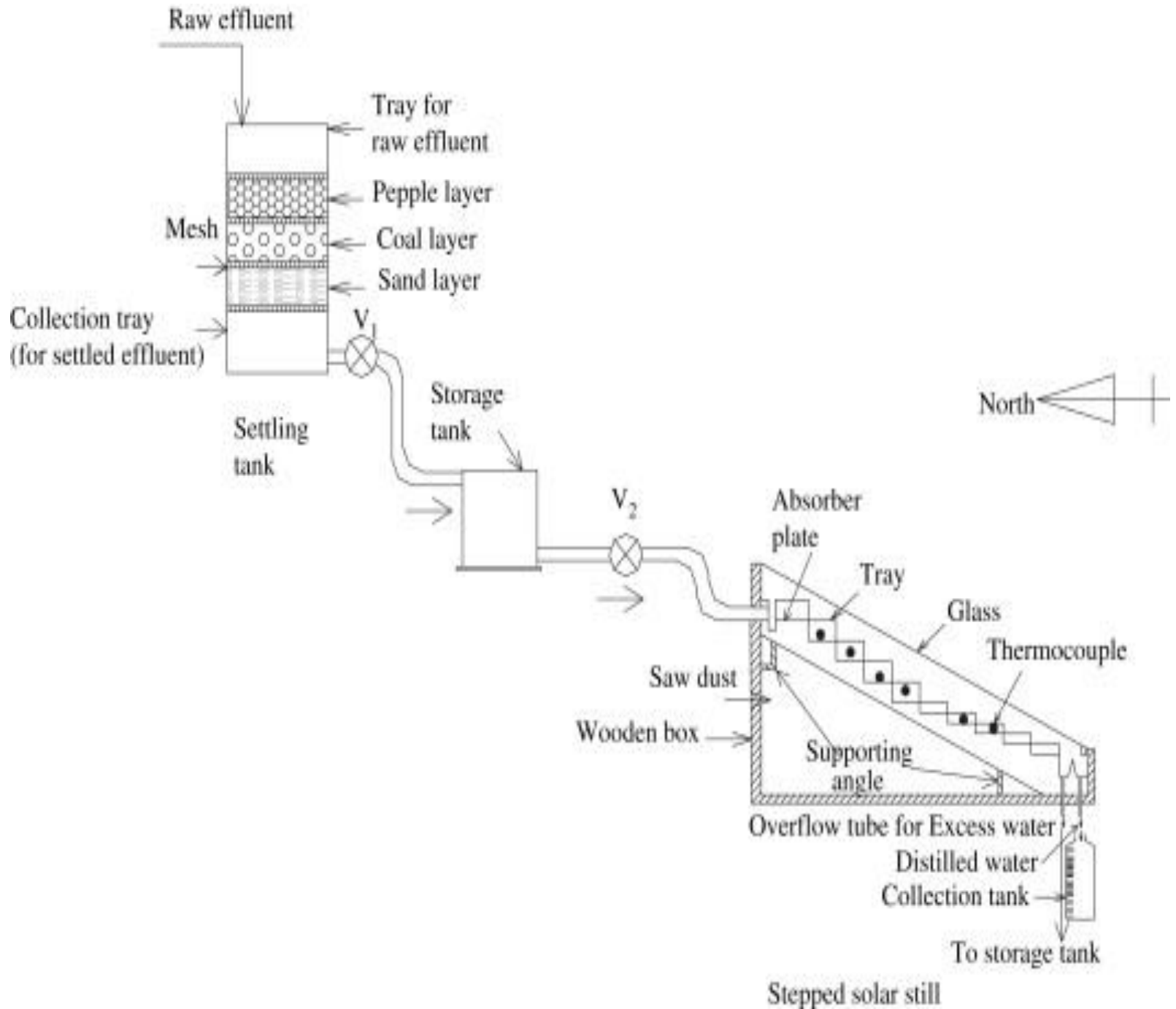

Fig.5 Schematic diagram of single basin single slope solar still with heat storage [53] 


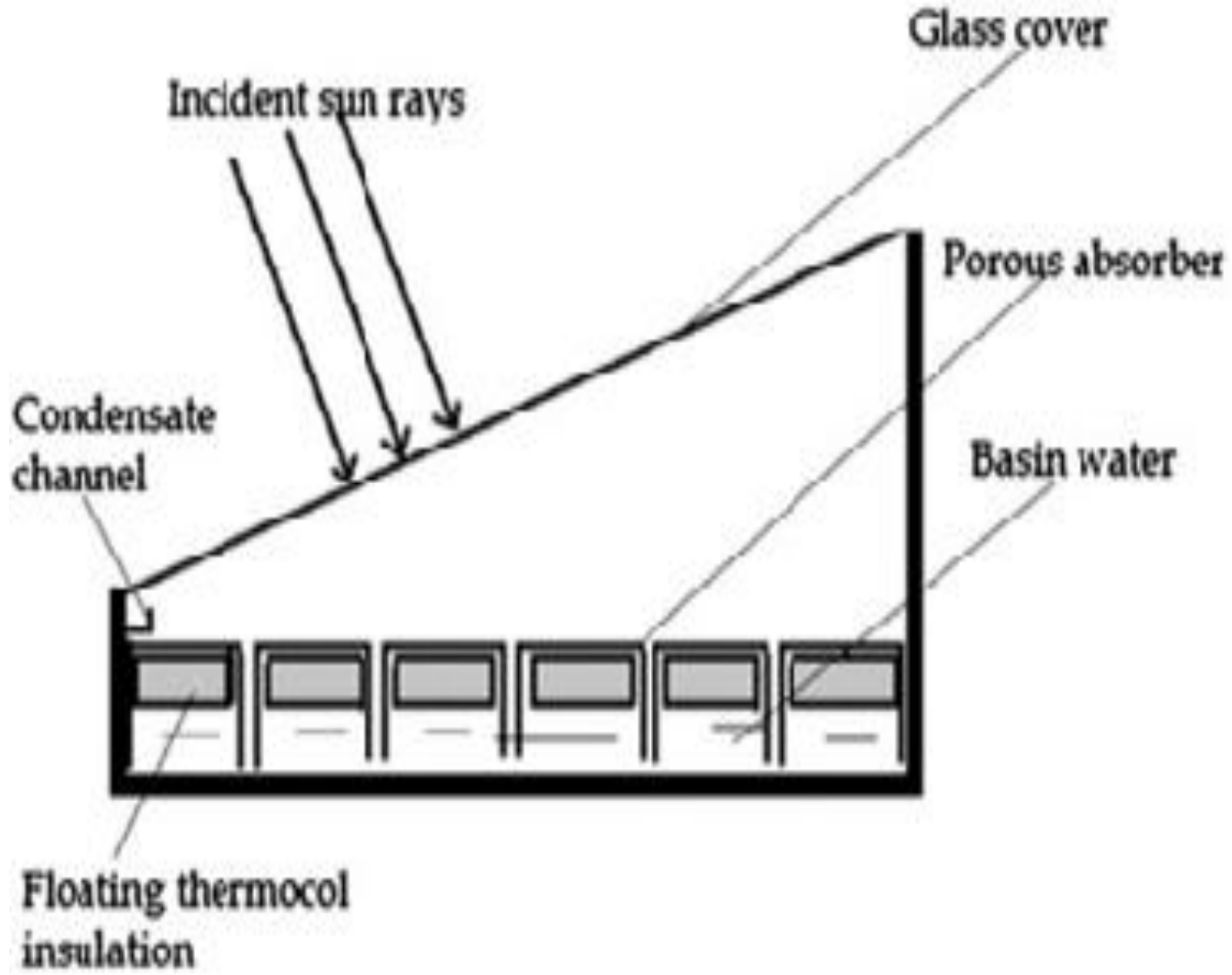

Fig.6 Schematic diagram of single basin single slope solar still with porous absorber [55] 


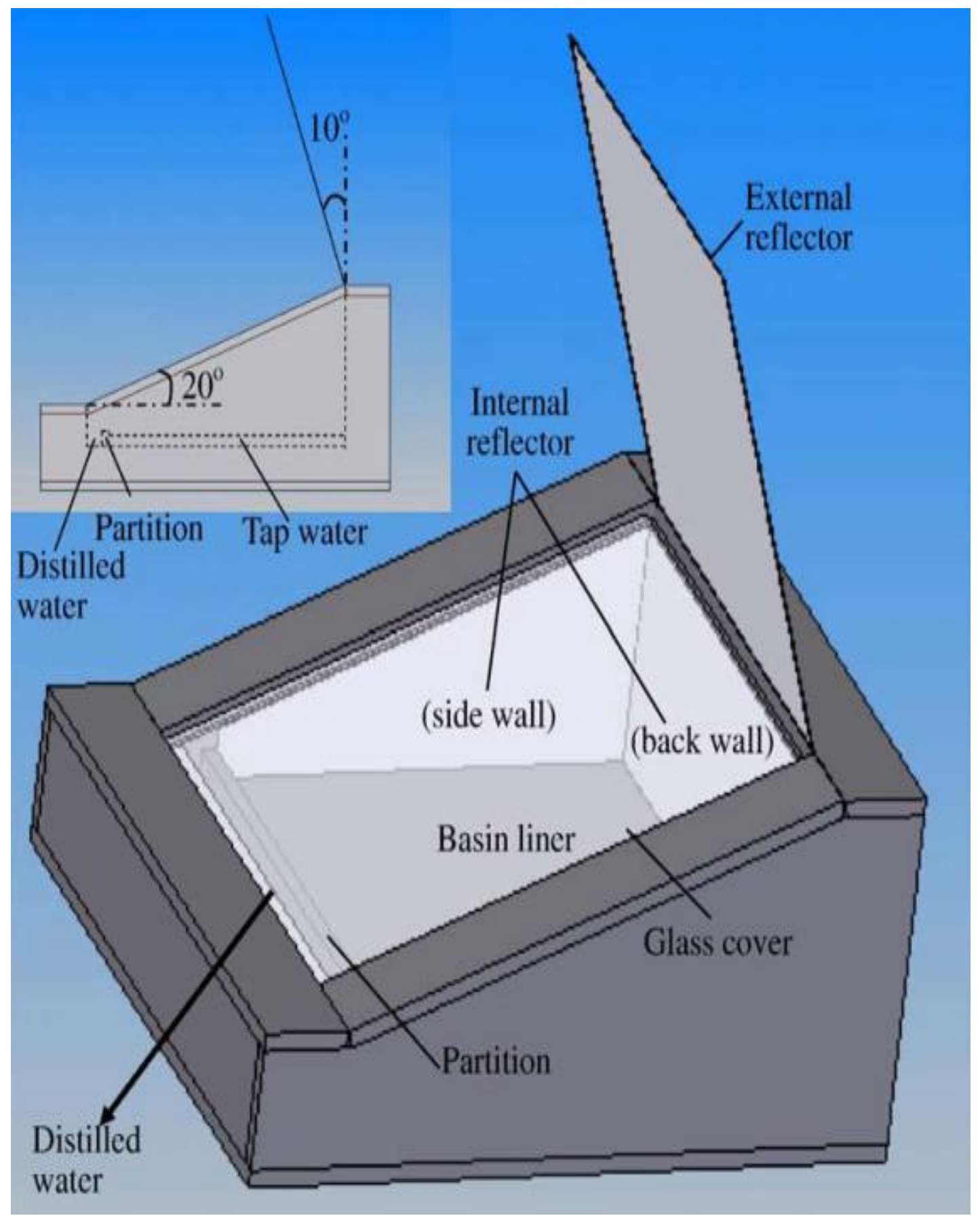

Fig.7 Schematic diagram of single basin single slope solar still with reflector [40] 
(Thermo-couple Locationsis)

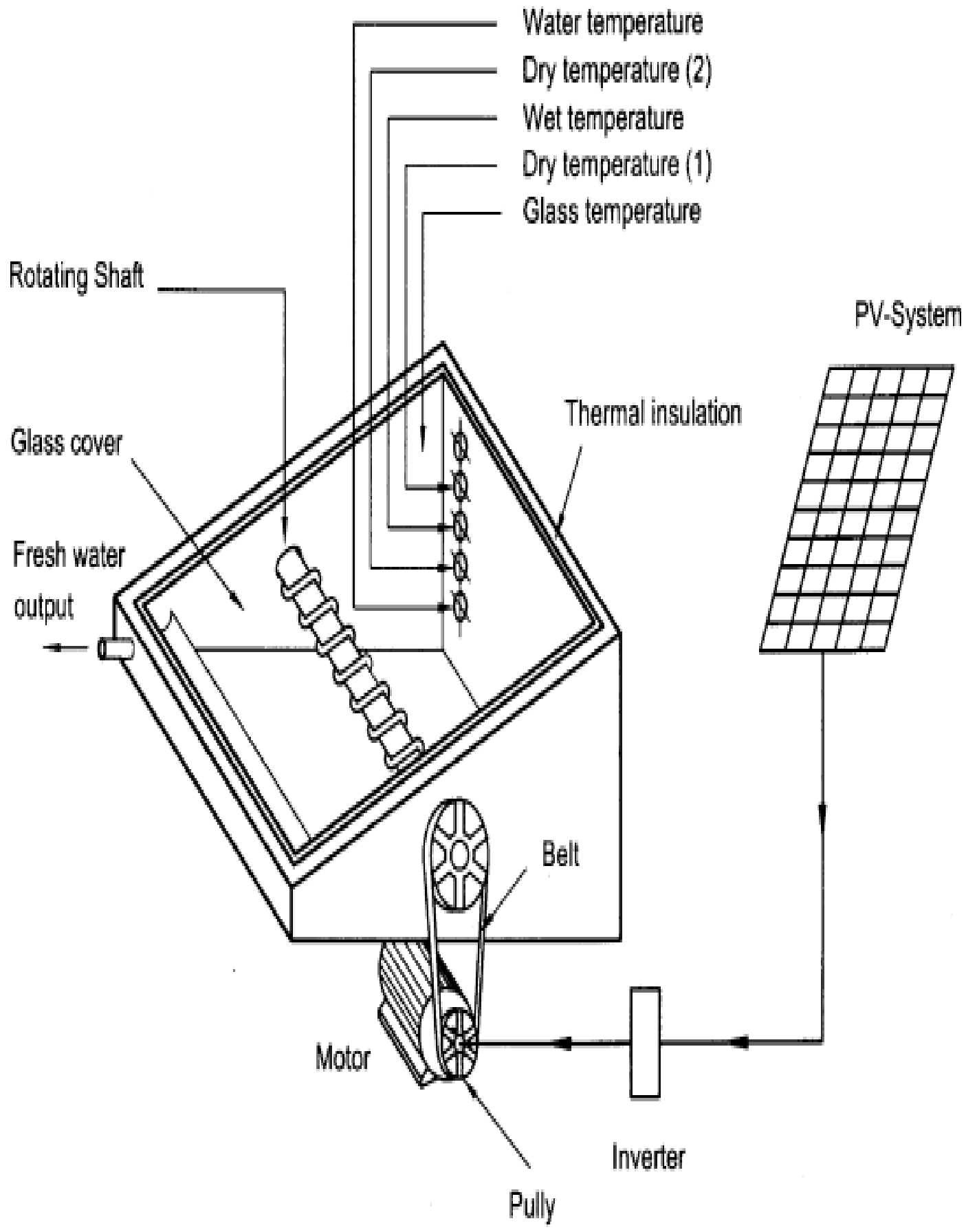

Fig.8 Schematic diagram of single basin single slope solar still with rotating shaft [142] 


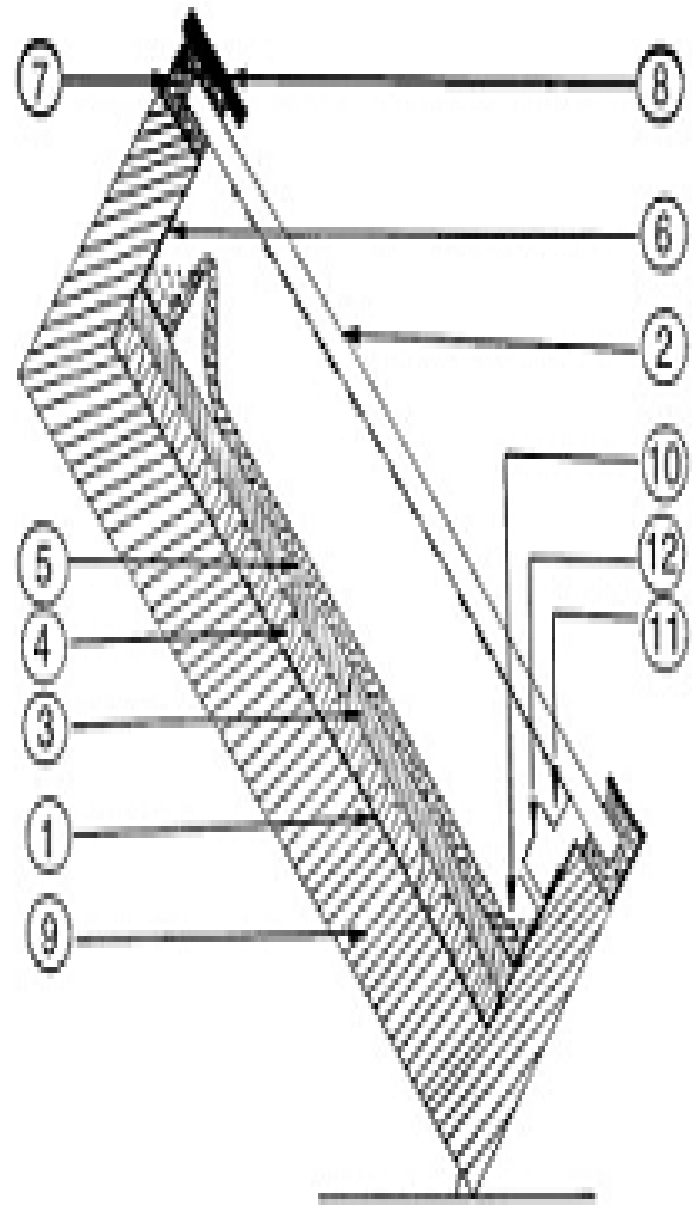

(1) Gevarised steal tray, (2) glass cover, (3) support board, (4) polystyene, (5) chacos doth, (6) aluminum channel, (7) rubber gasket, (8) stese:strip, (9) styrofosm, (10) brine gutter, (11) distillate gutter, and (12) distillate outlet channel.

Fig.9 Schematic diagram of single basin single slope solar still with wick [47] 


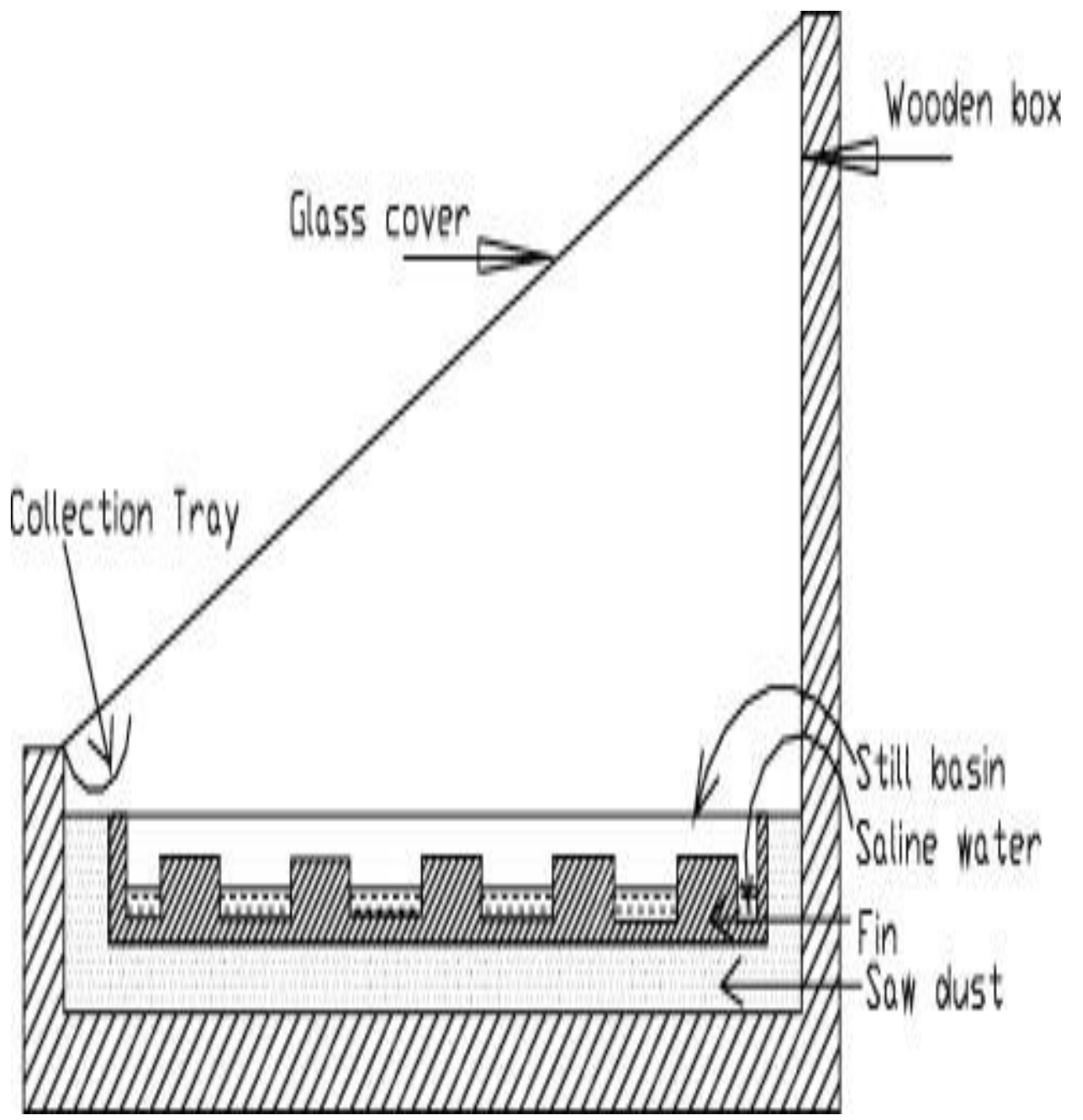

Fig.10 Schematic diagram of single basin single slope solar still with fin [49] 


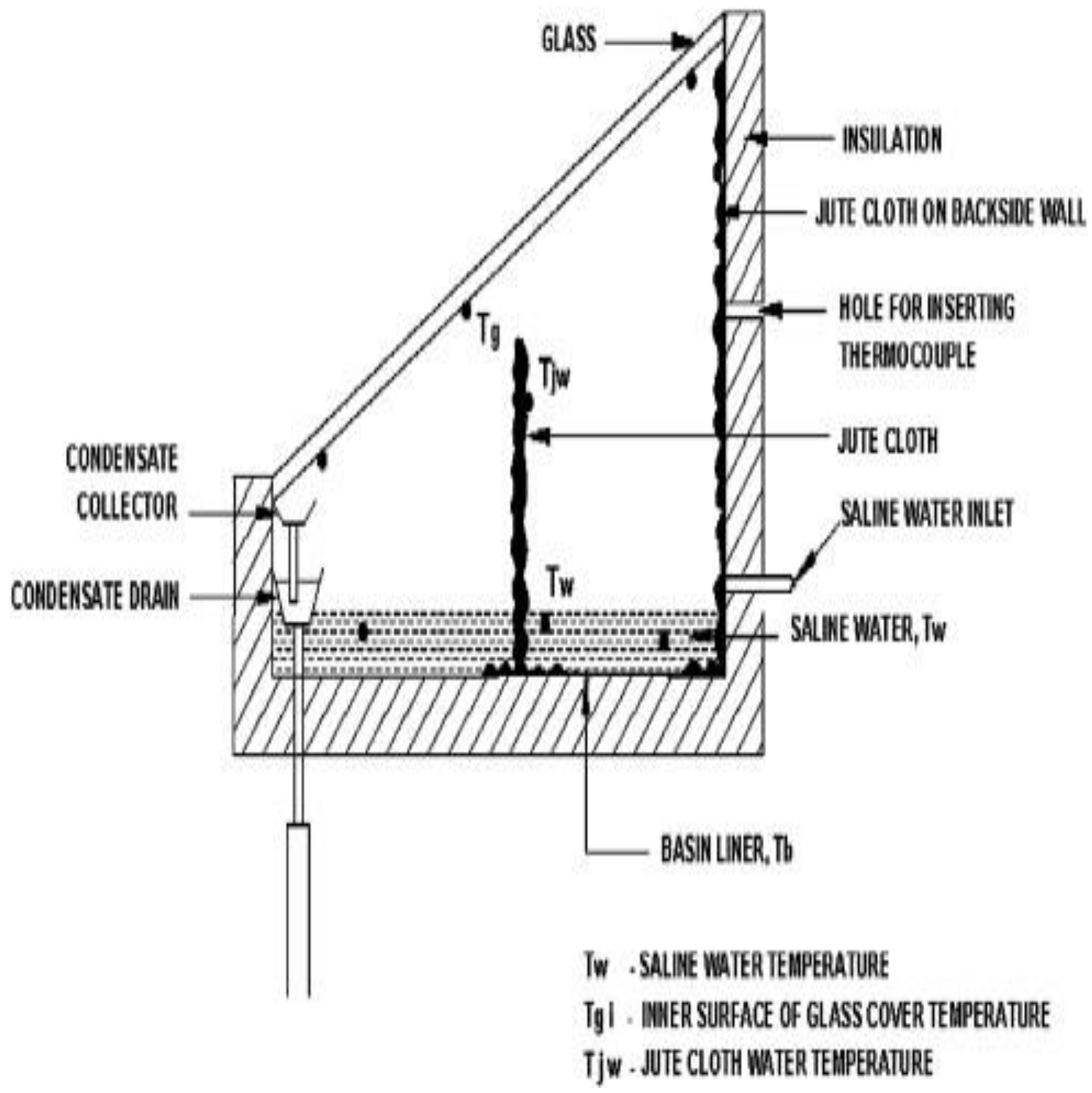

Fig.11 Schematic diagram of single basin single slope regenerative solar still [137] 


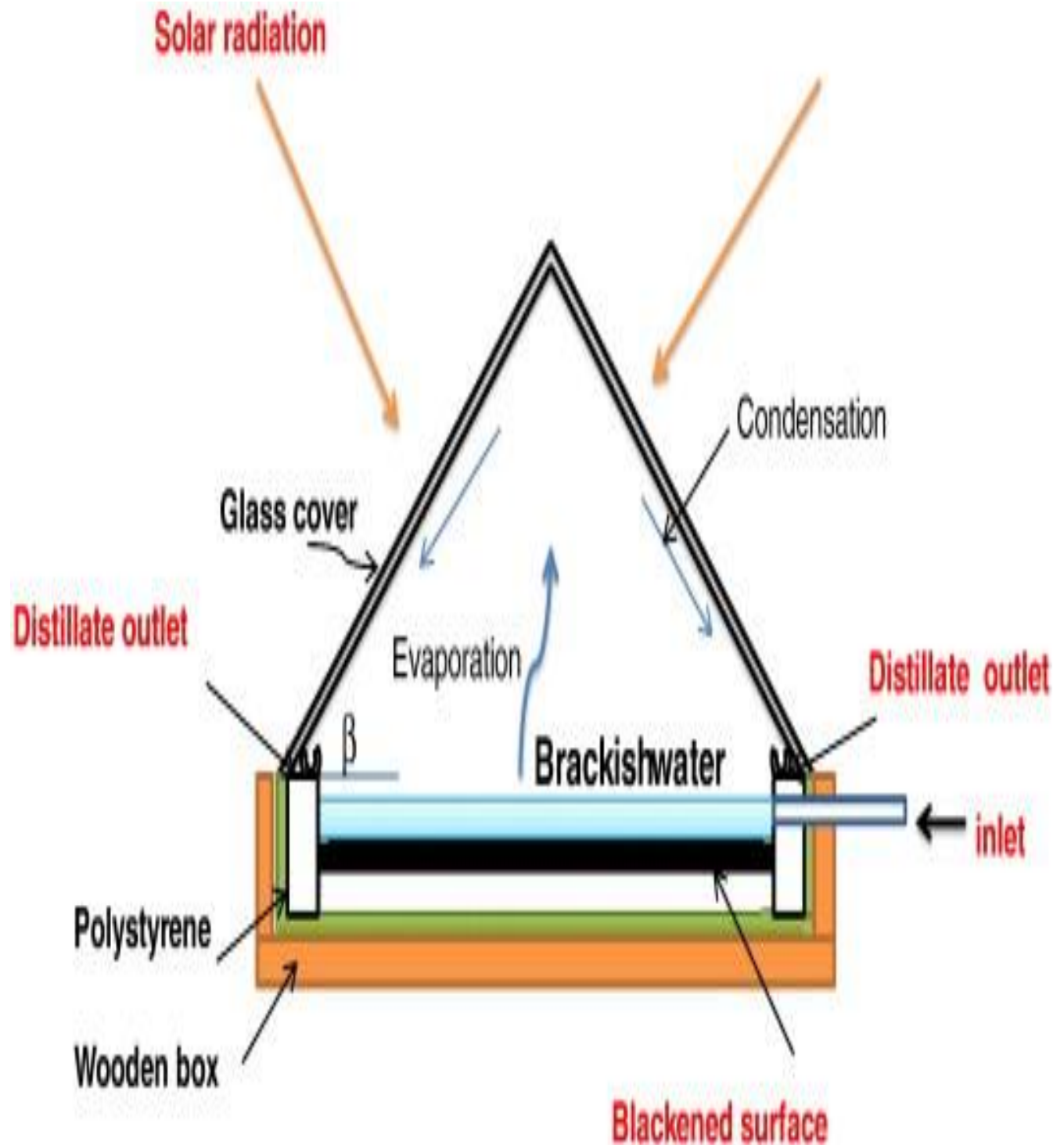

Fig.12 Schematic diagram of single basin simple double slope solar still [87] 


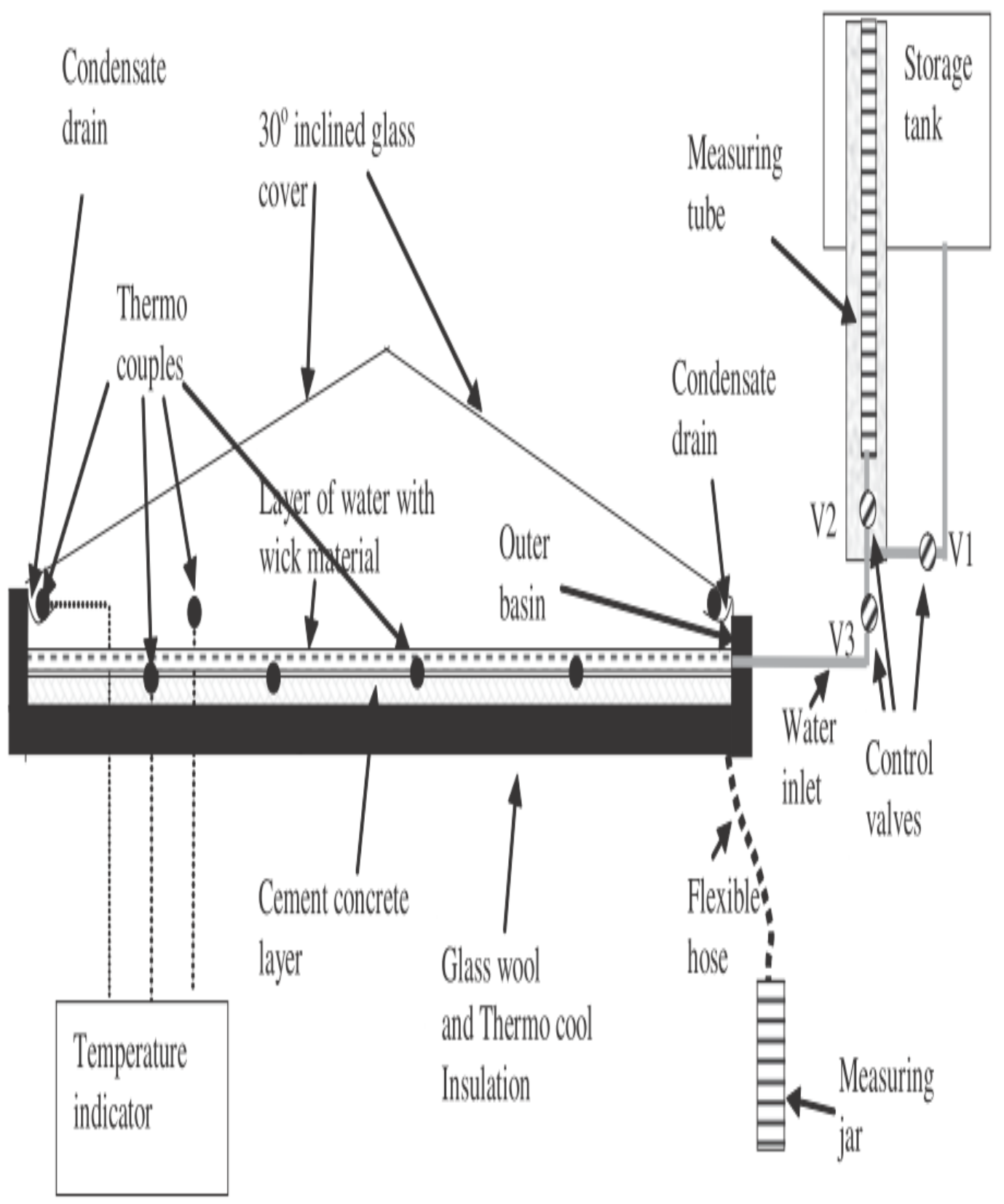

Fig.13 Schematic diagram of single basin double slope solar still with wick [60] 


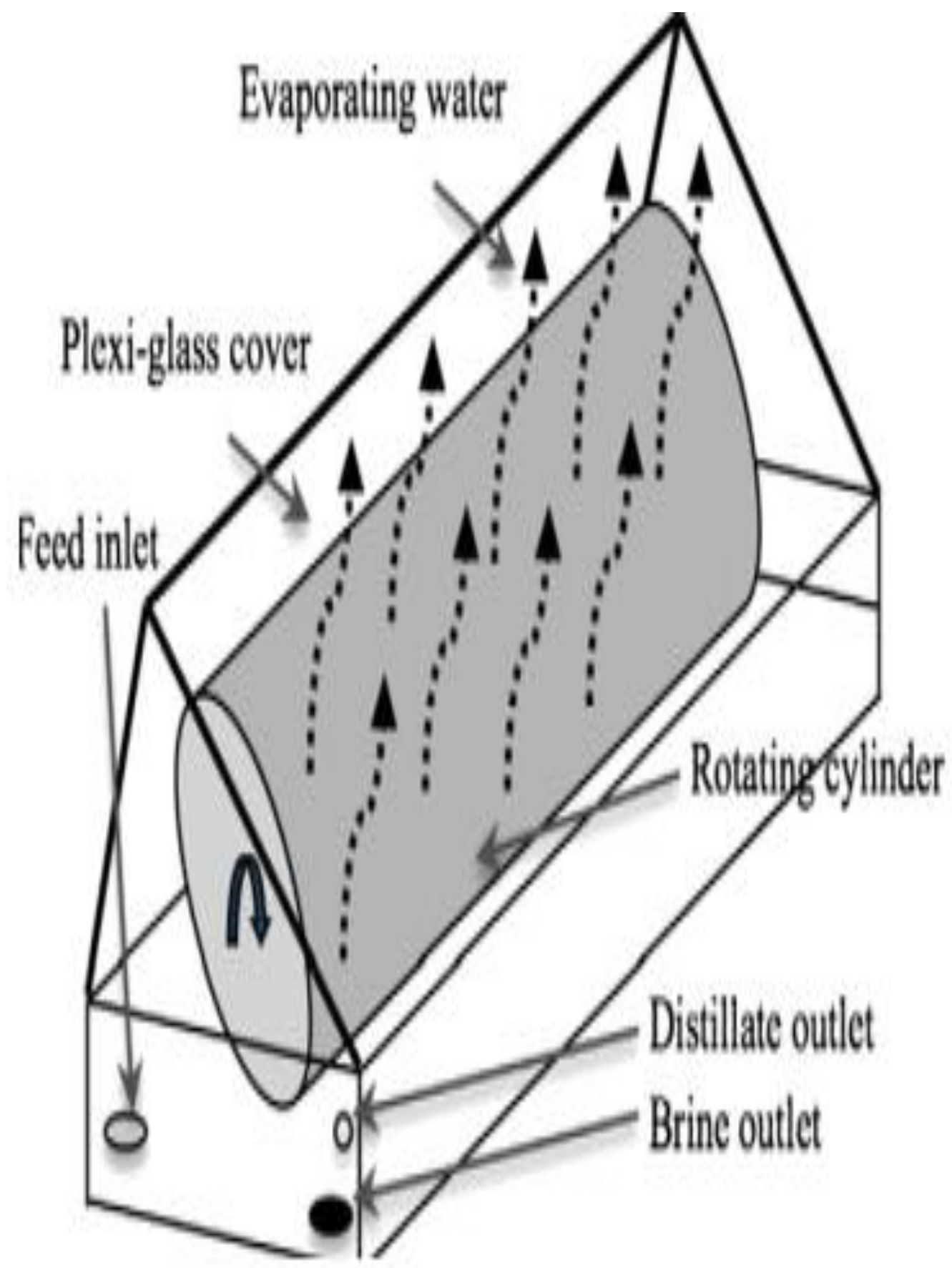

Fig.14 Schematic diagram of single basin double slope solar still with rotating cylinder 


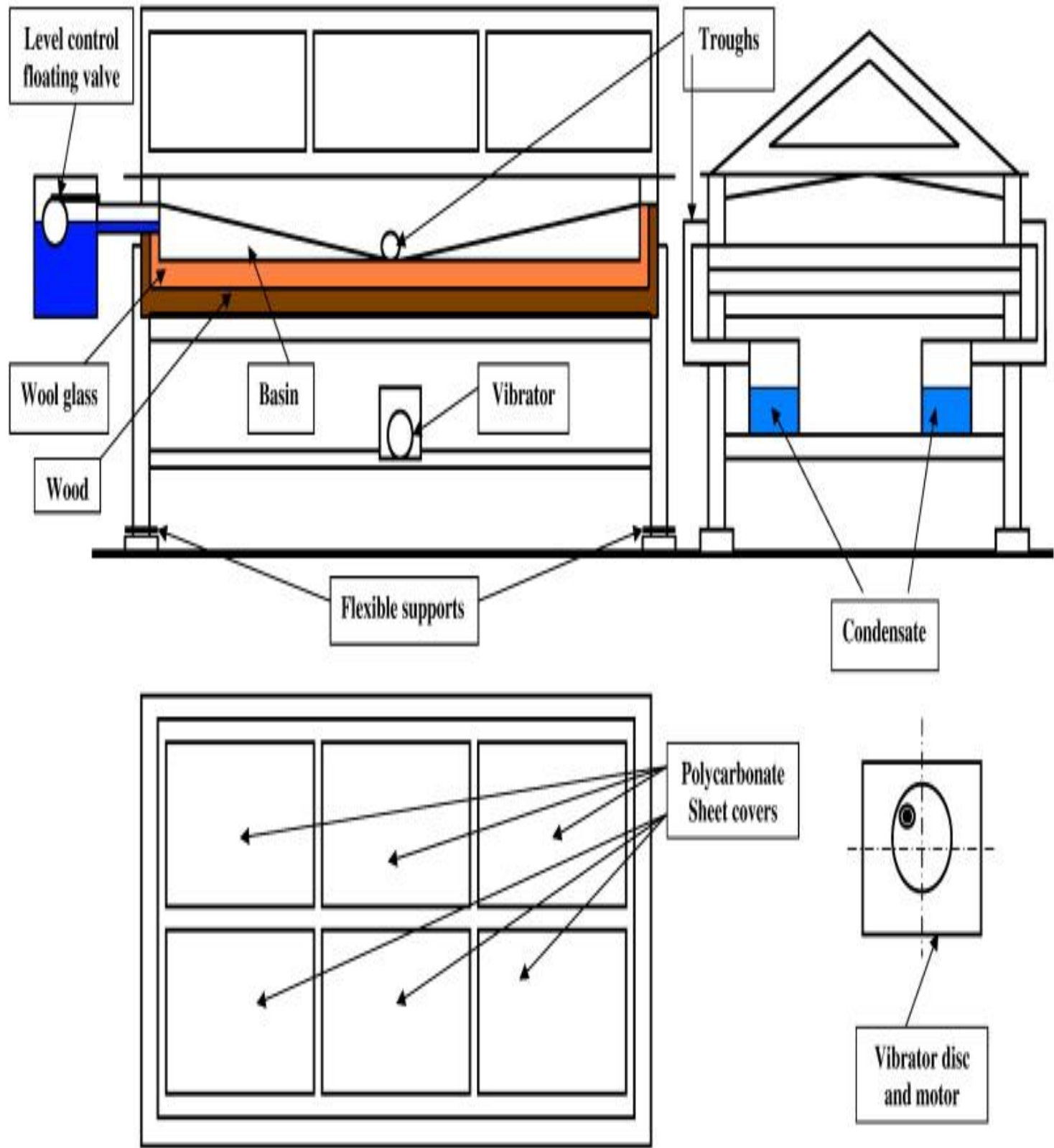

Fig.15 Schematic diagram of single basin double slope solar still with vibratory harmonic effect [146] 


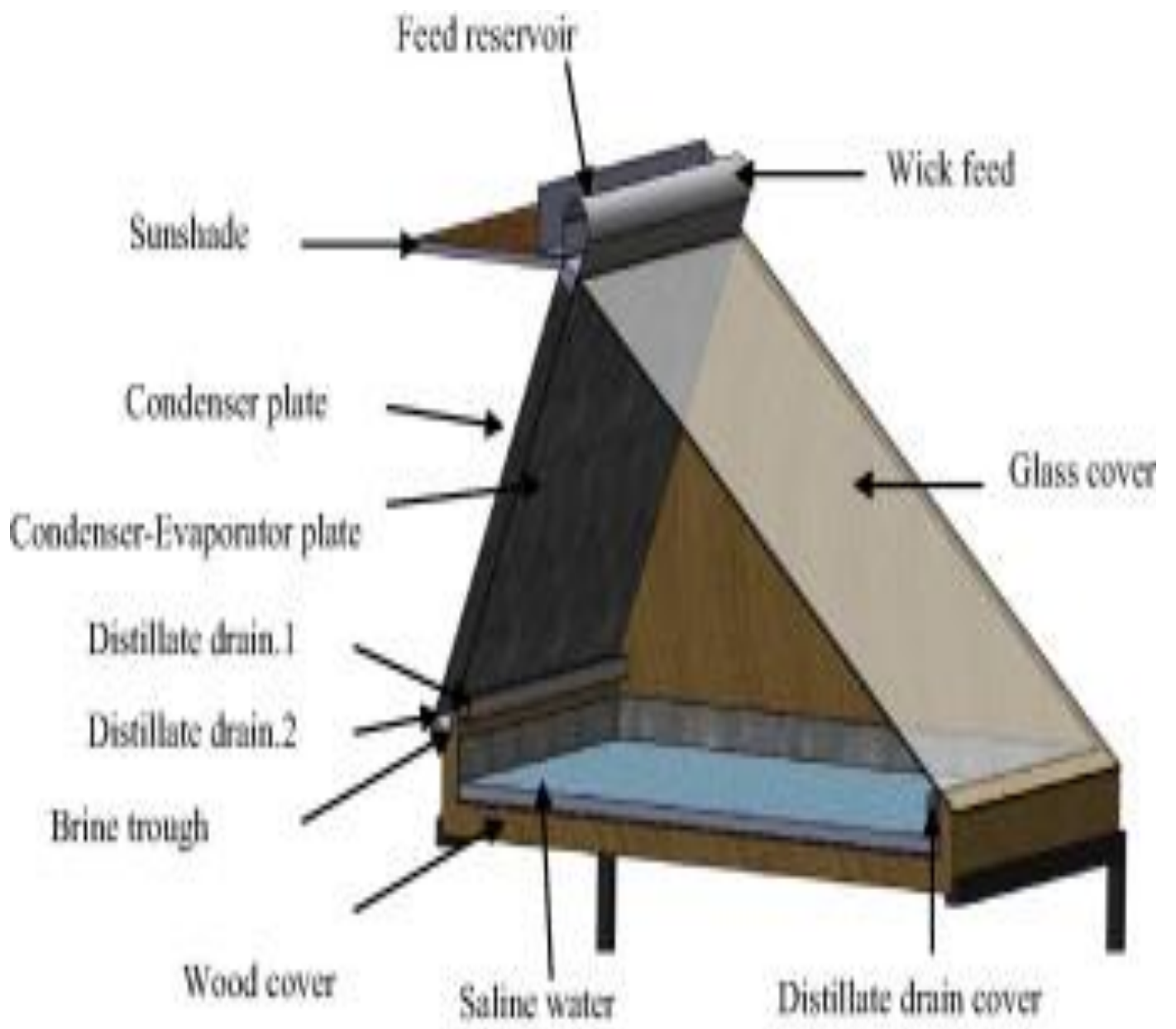

Fig.16 Schematic diagram of single basin double slope solar still with condenser [133] 


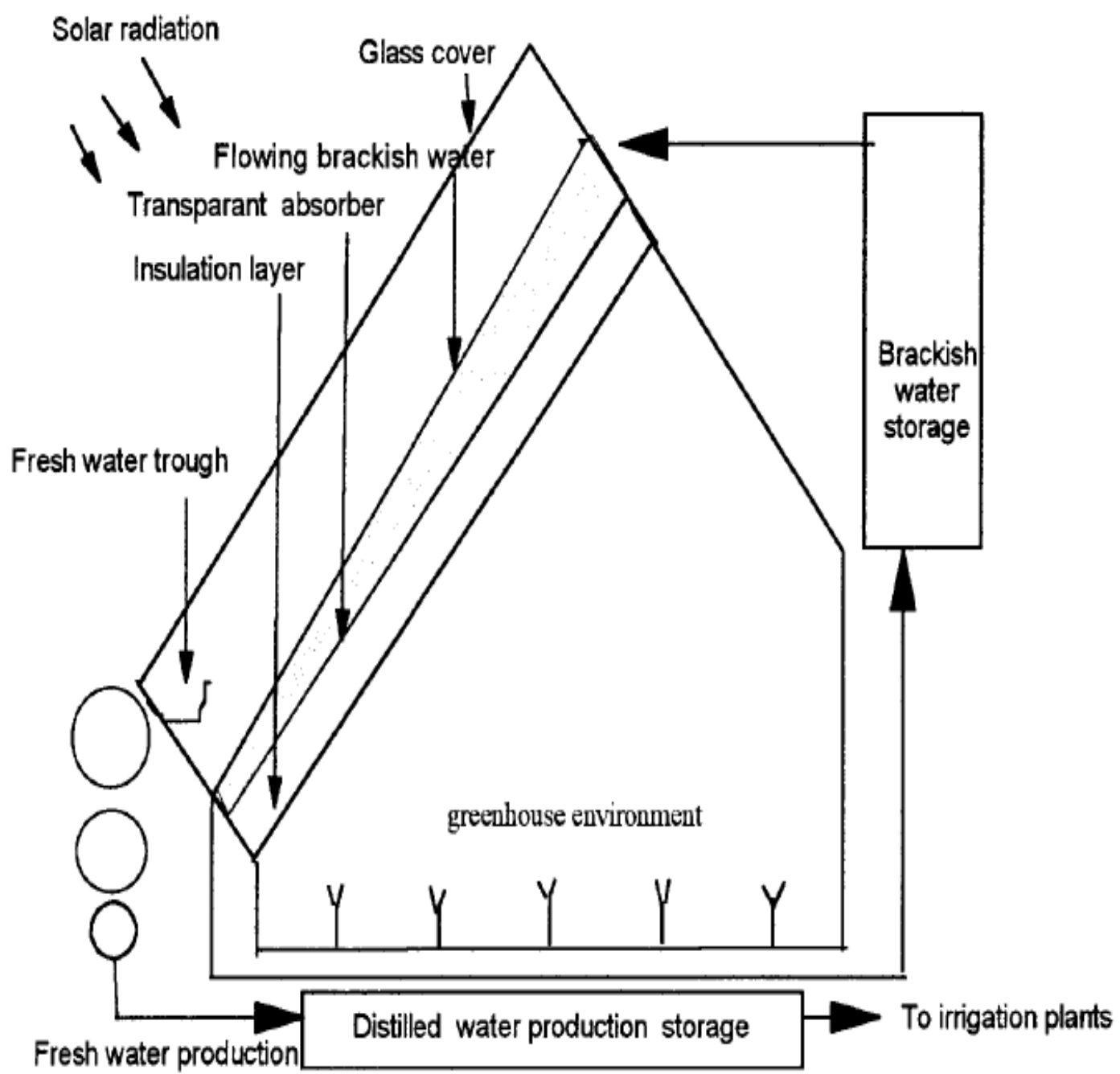

Fig.17 Schematic diagram of single basin greenhouse type double slope solar still [161] 
Figure

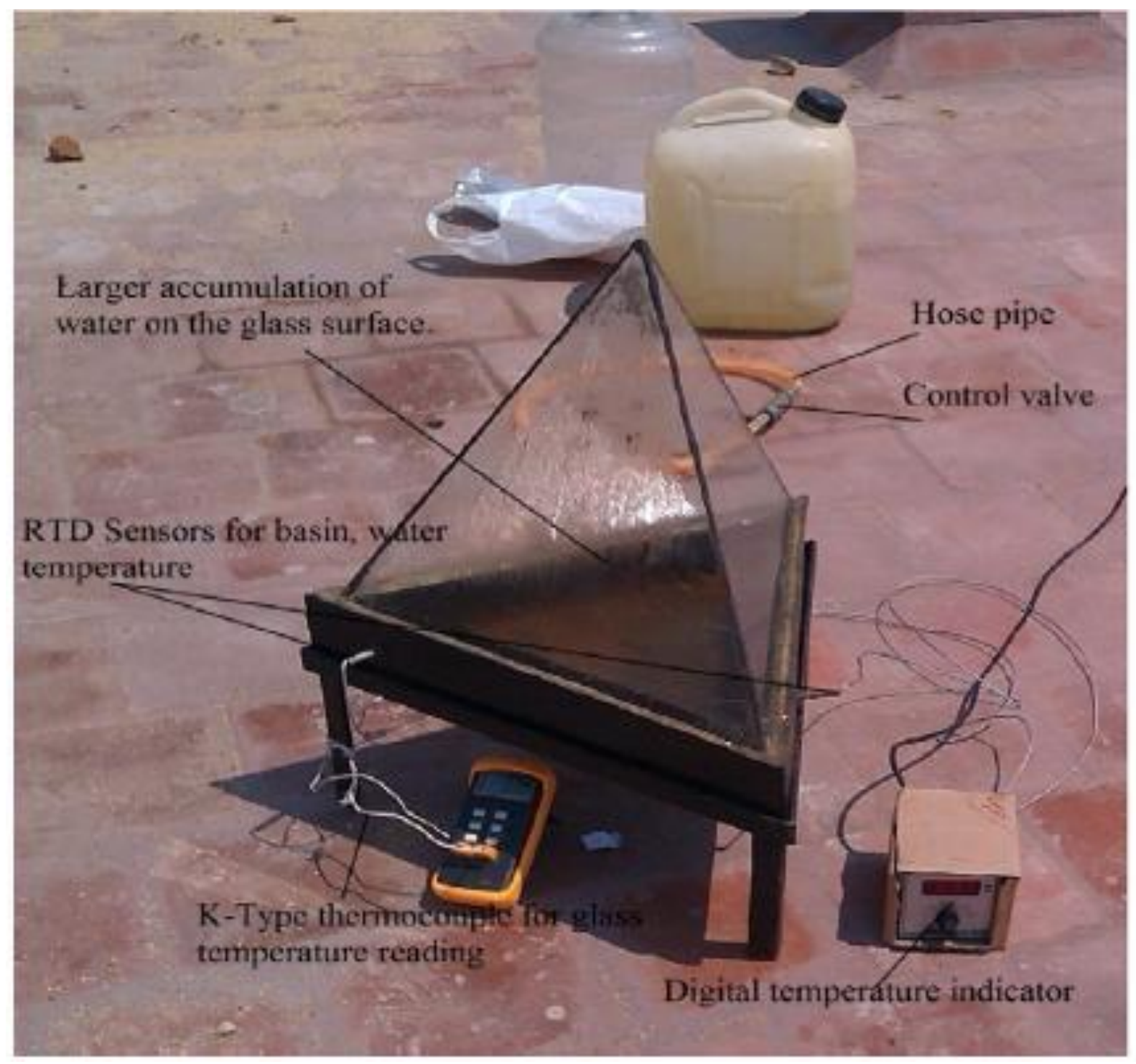

Fig.18 Schematic diagram of single basin triangular solar still [21] 
Figure
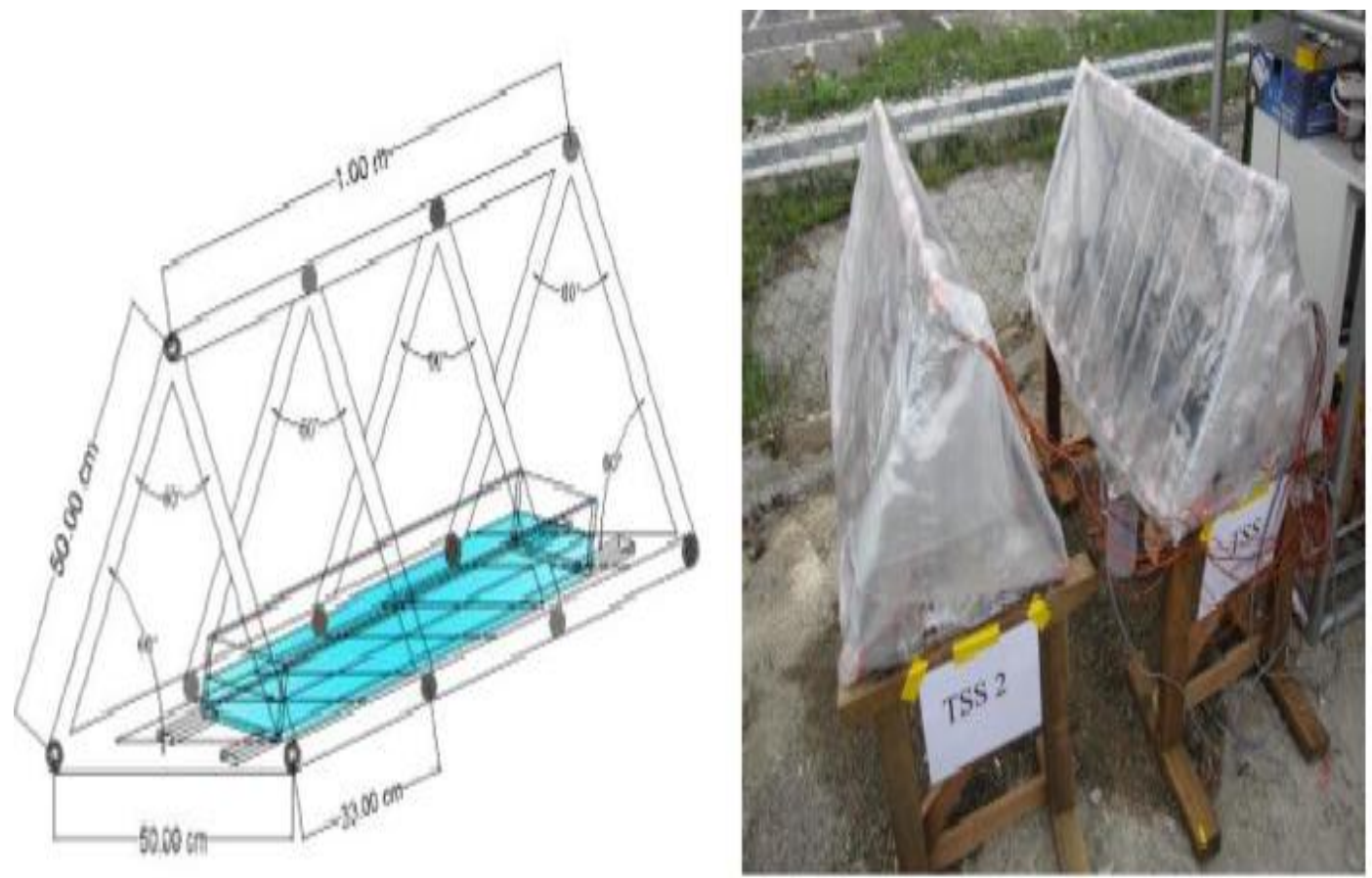

Fig.19 Schematic diagram of single basin lengthy triangular solar still [72] 
Figure

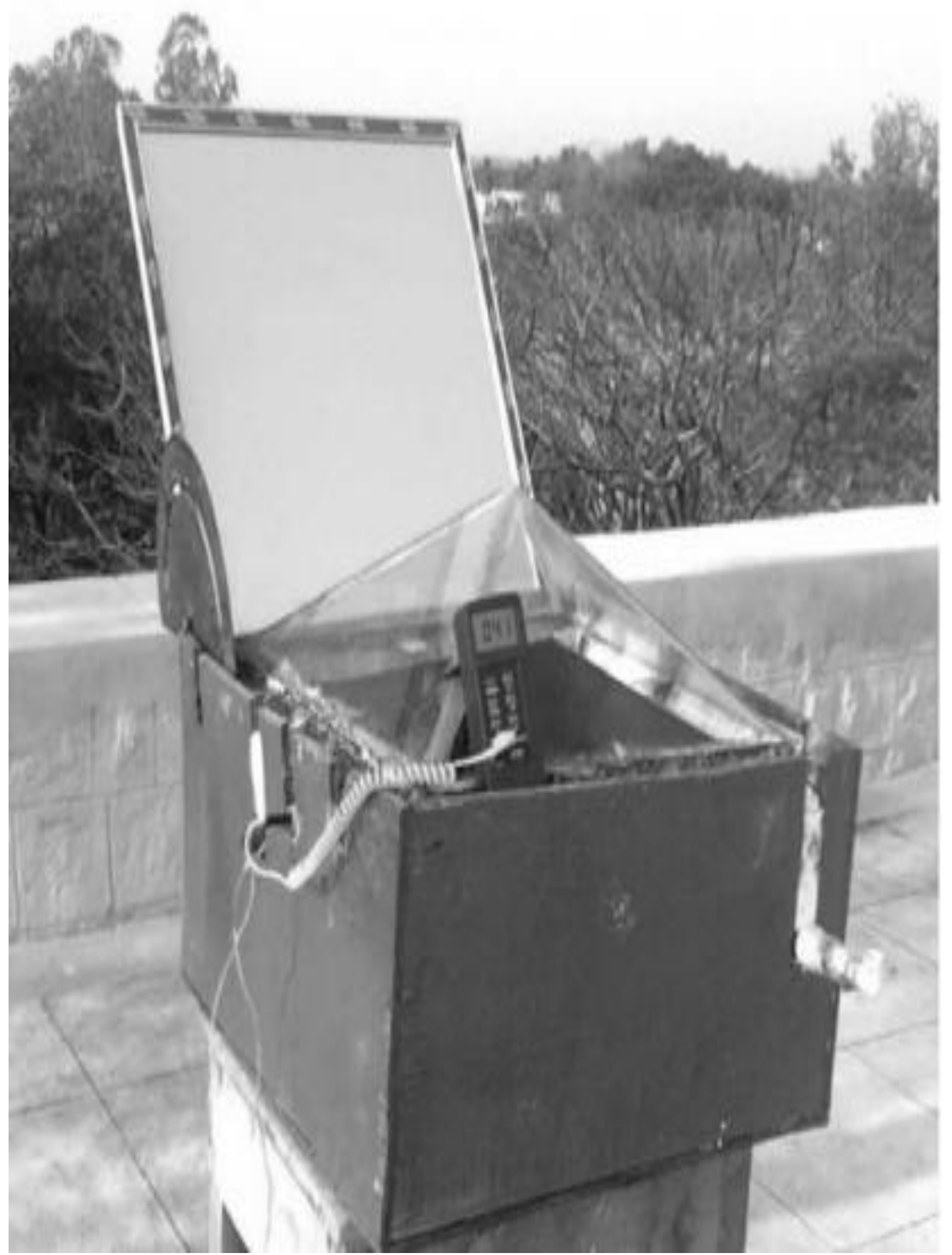

Fig.20 Schematic diagram of single basin triangular solar still with mirror booster [74] 
Figure

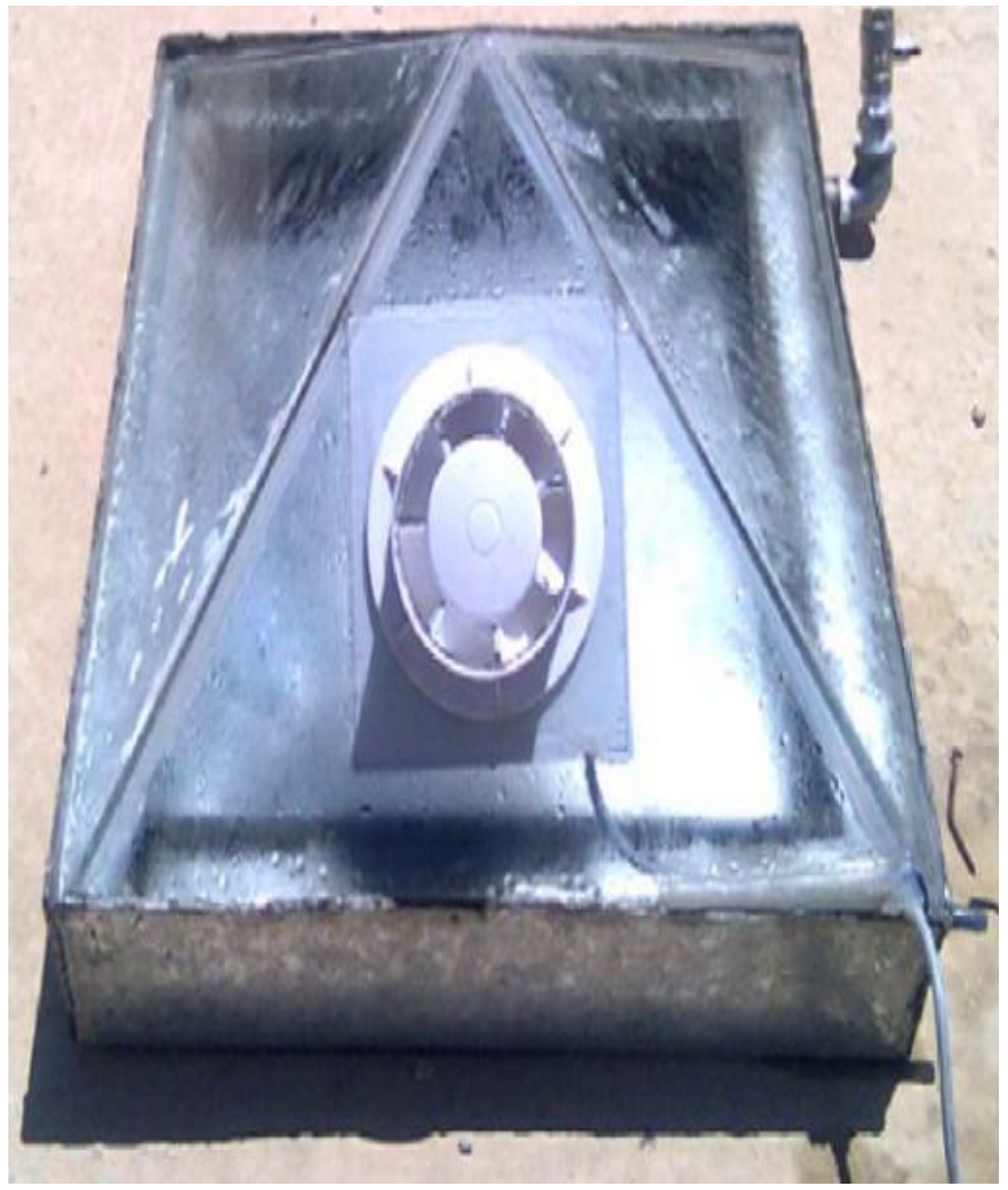

Fig.21 Schematic diagram of single basin triangular solar still with fan [71] 


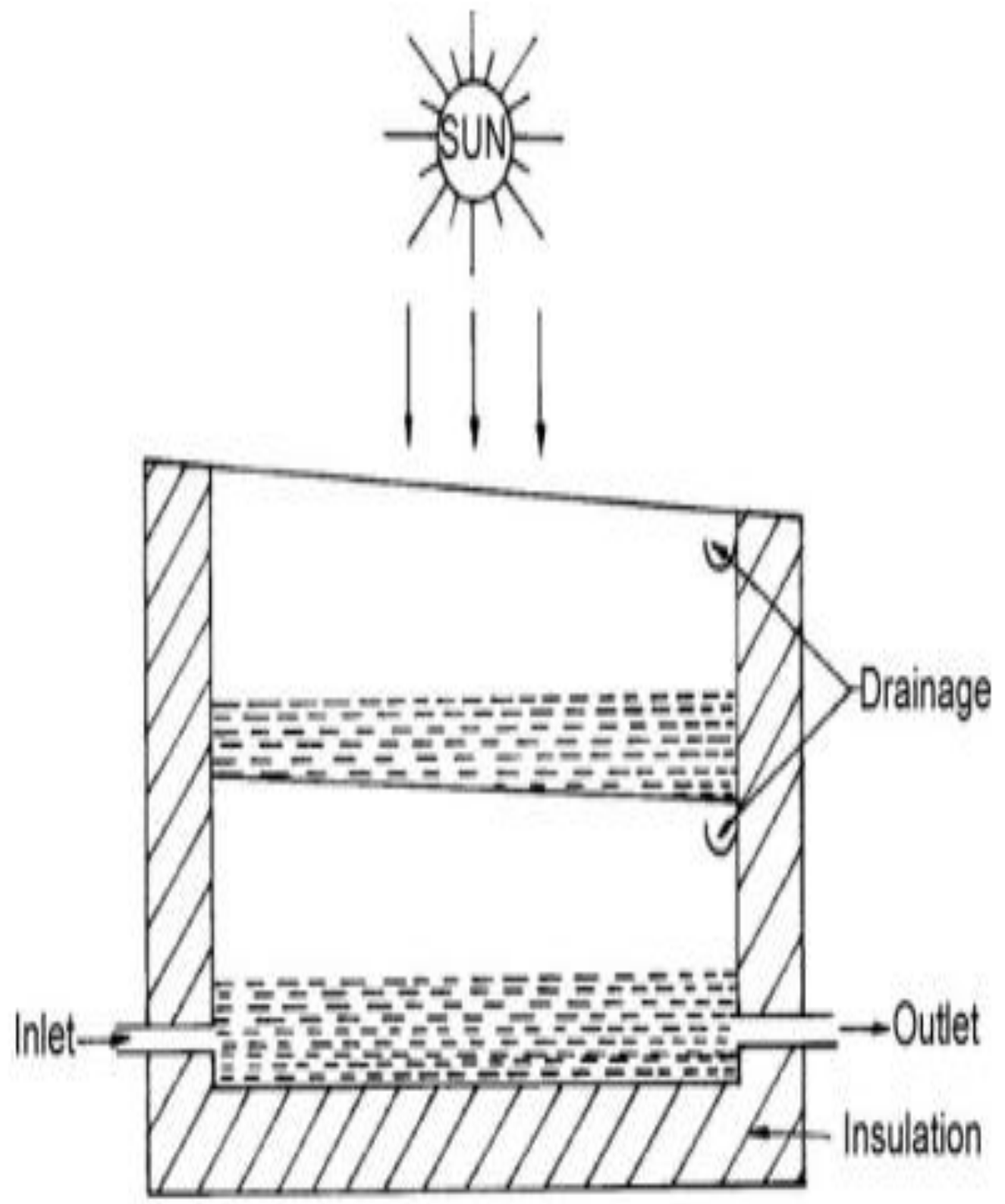

Fig.22 Schematic diagram of double basin solar still [104] 


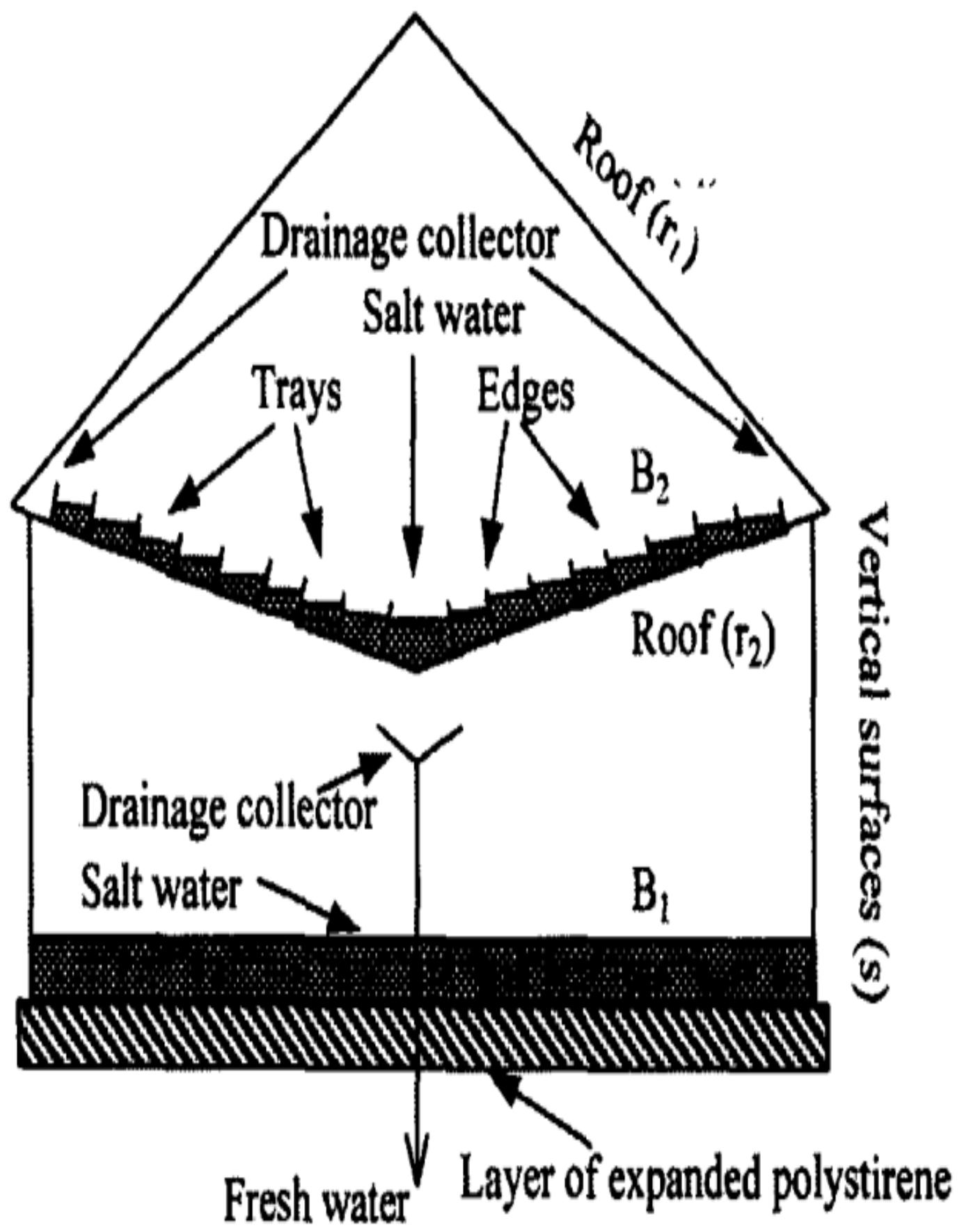

Fig.23 Schematic diagram of double basin plastic solar still [102] 
Figure

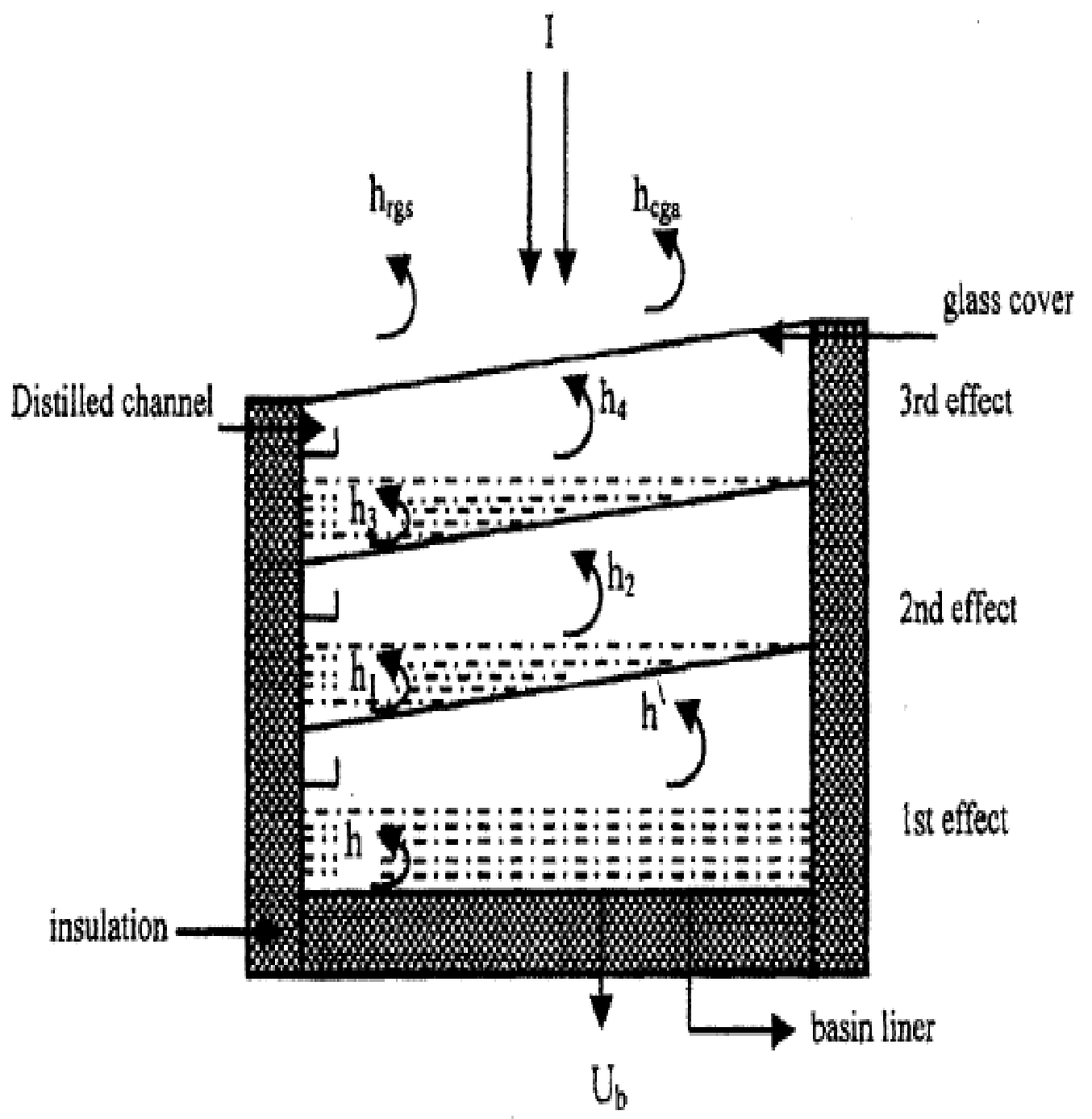

Fig.24 Schematic diagram of triple basin solar still [101] 


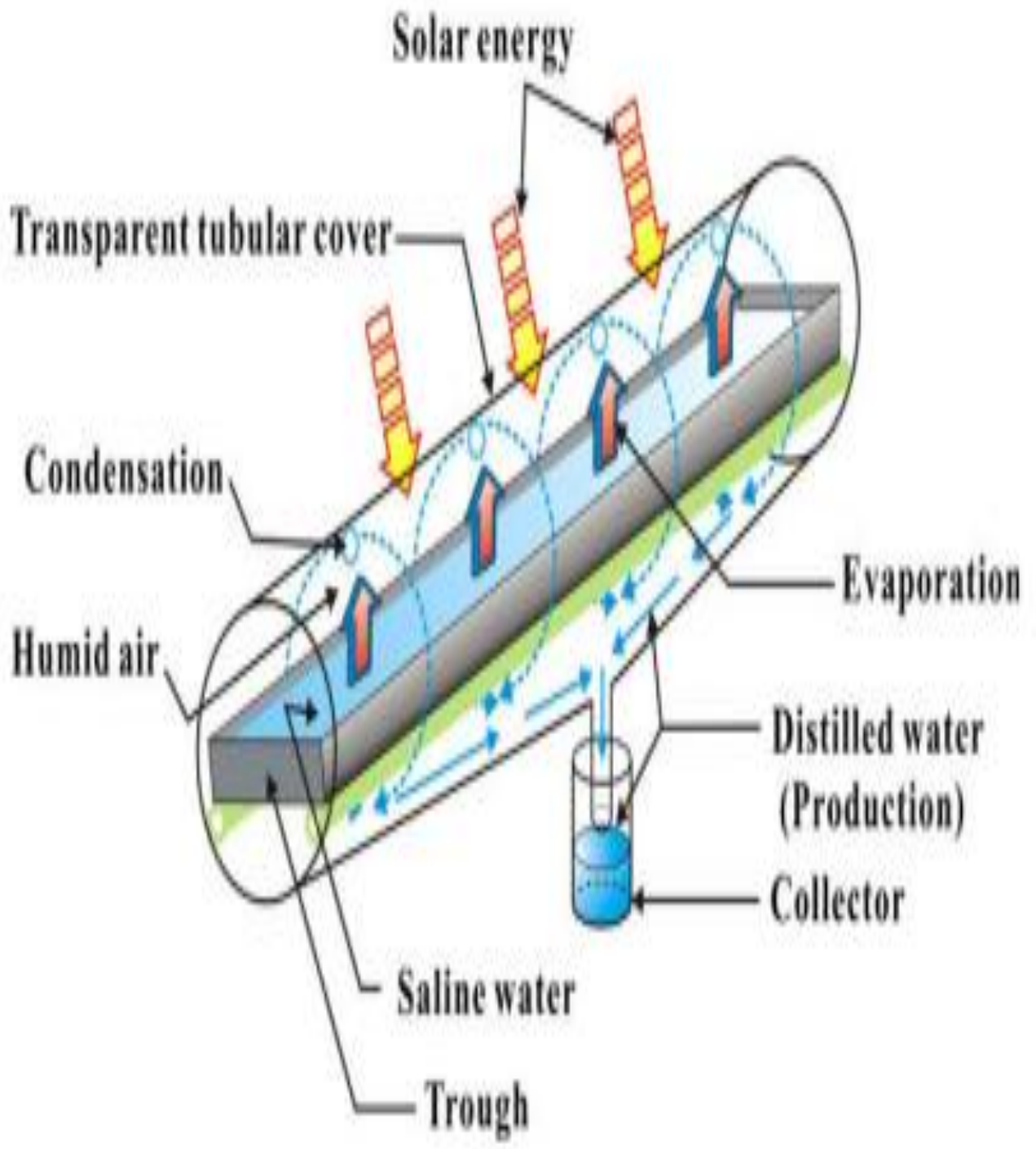

Fig.25 Schematic diagram of tubular solar still [75] 


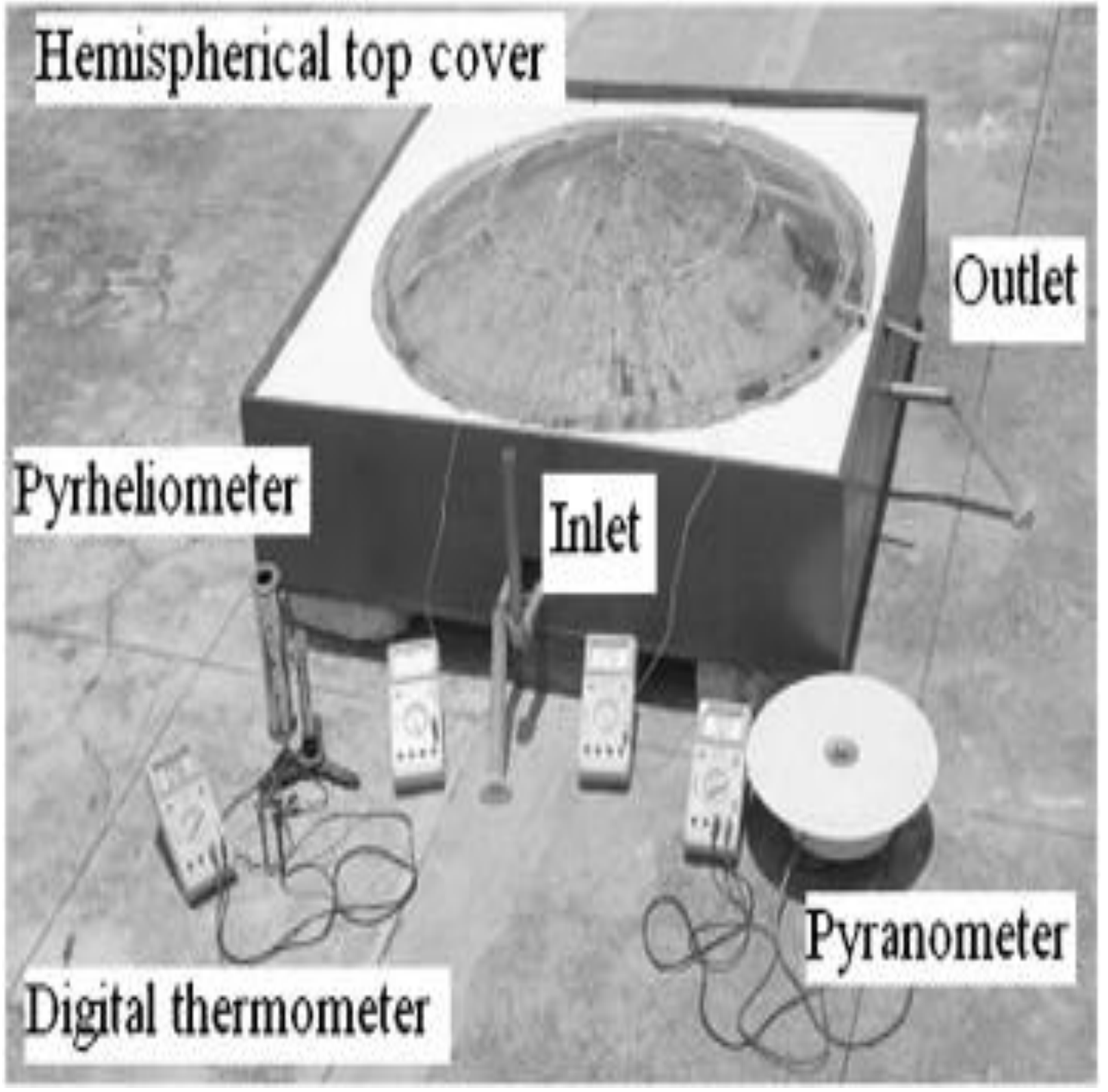

Fig.26 Schematic diagram of hemispherical solar still [80] 
Figure
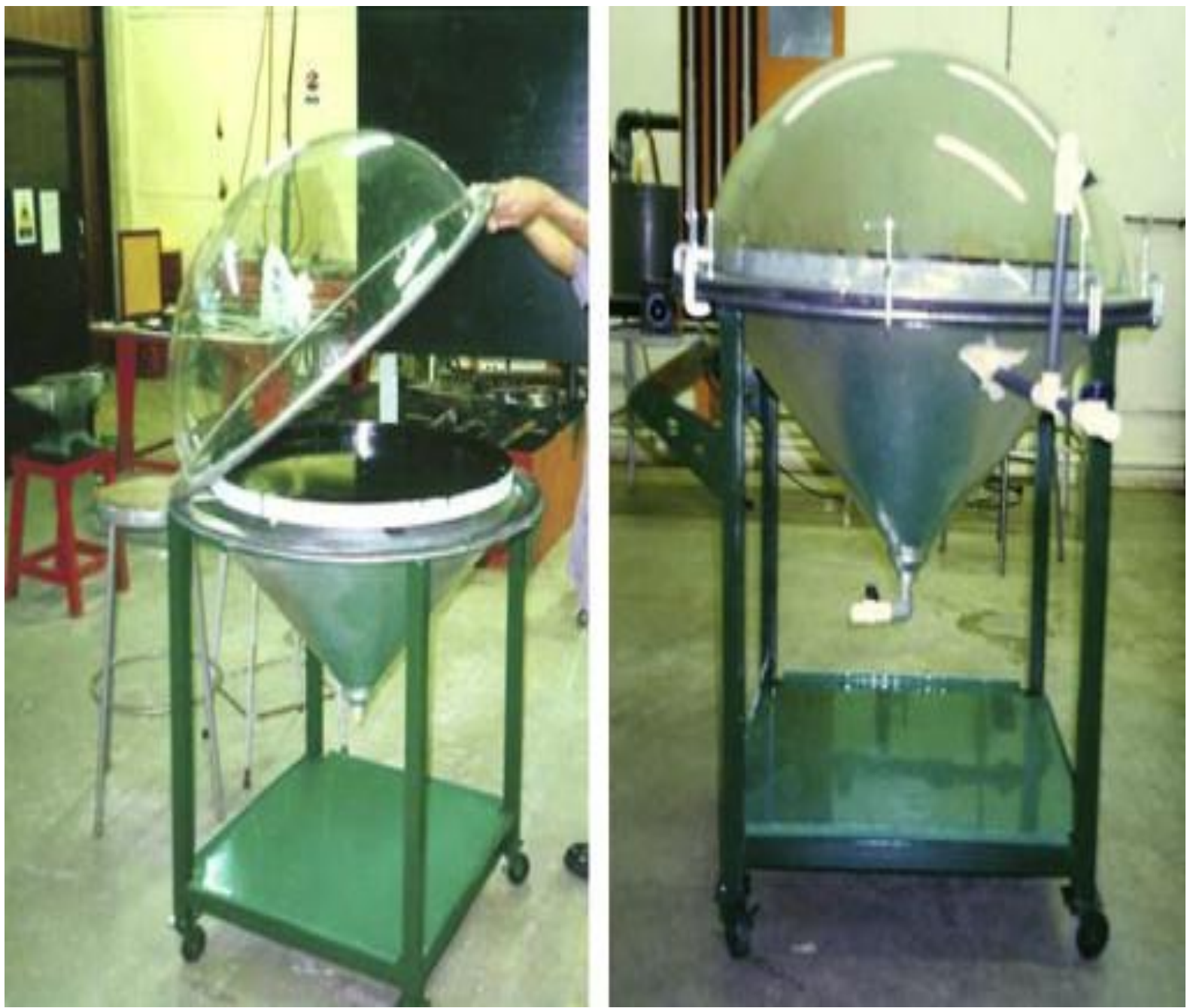

Fig.27 Schematic diagram of portable hemispherical solar still [81] 
Figure

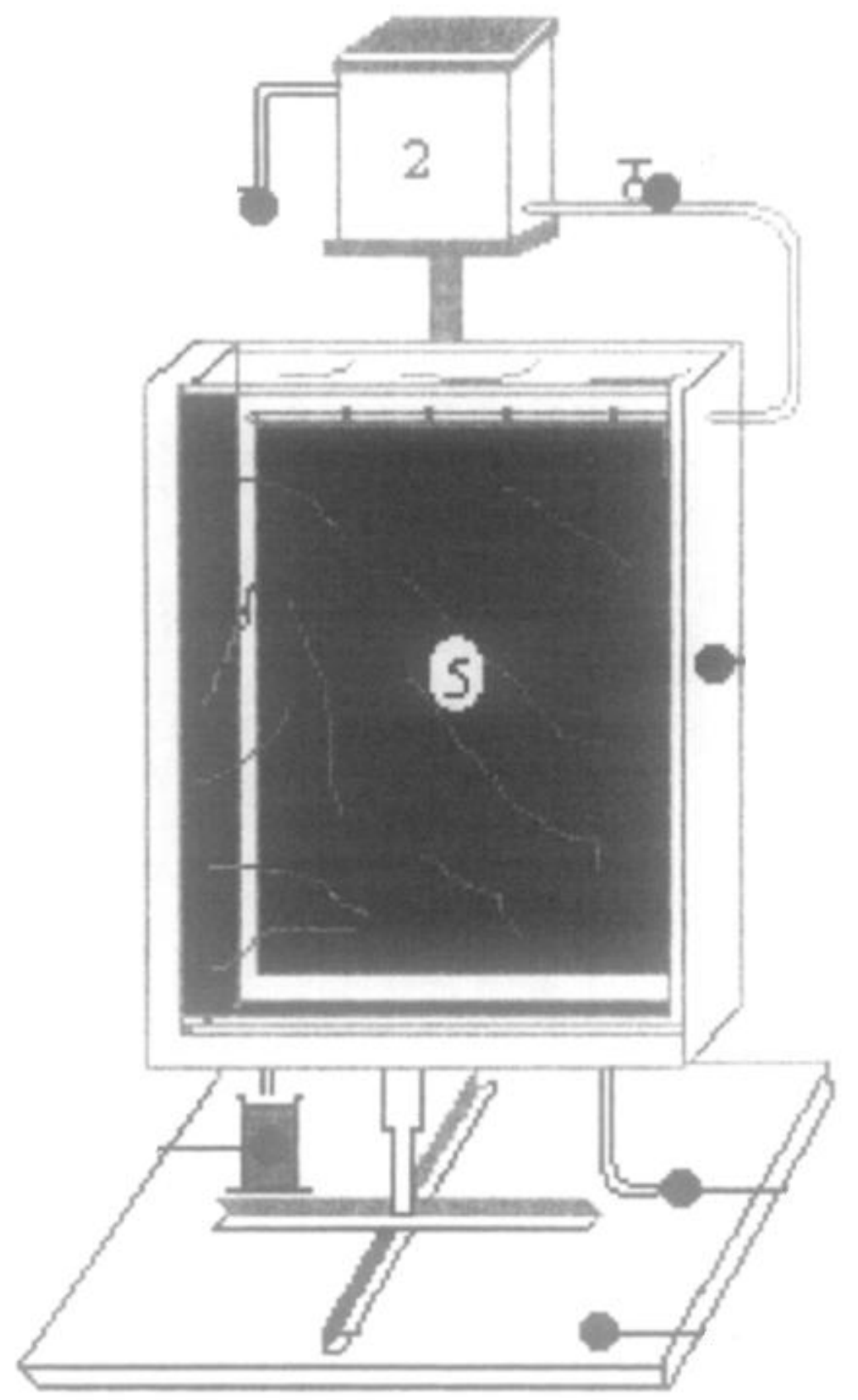

Fig.28 Schematic diagram of vertical solar still [91] 


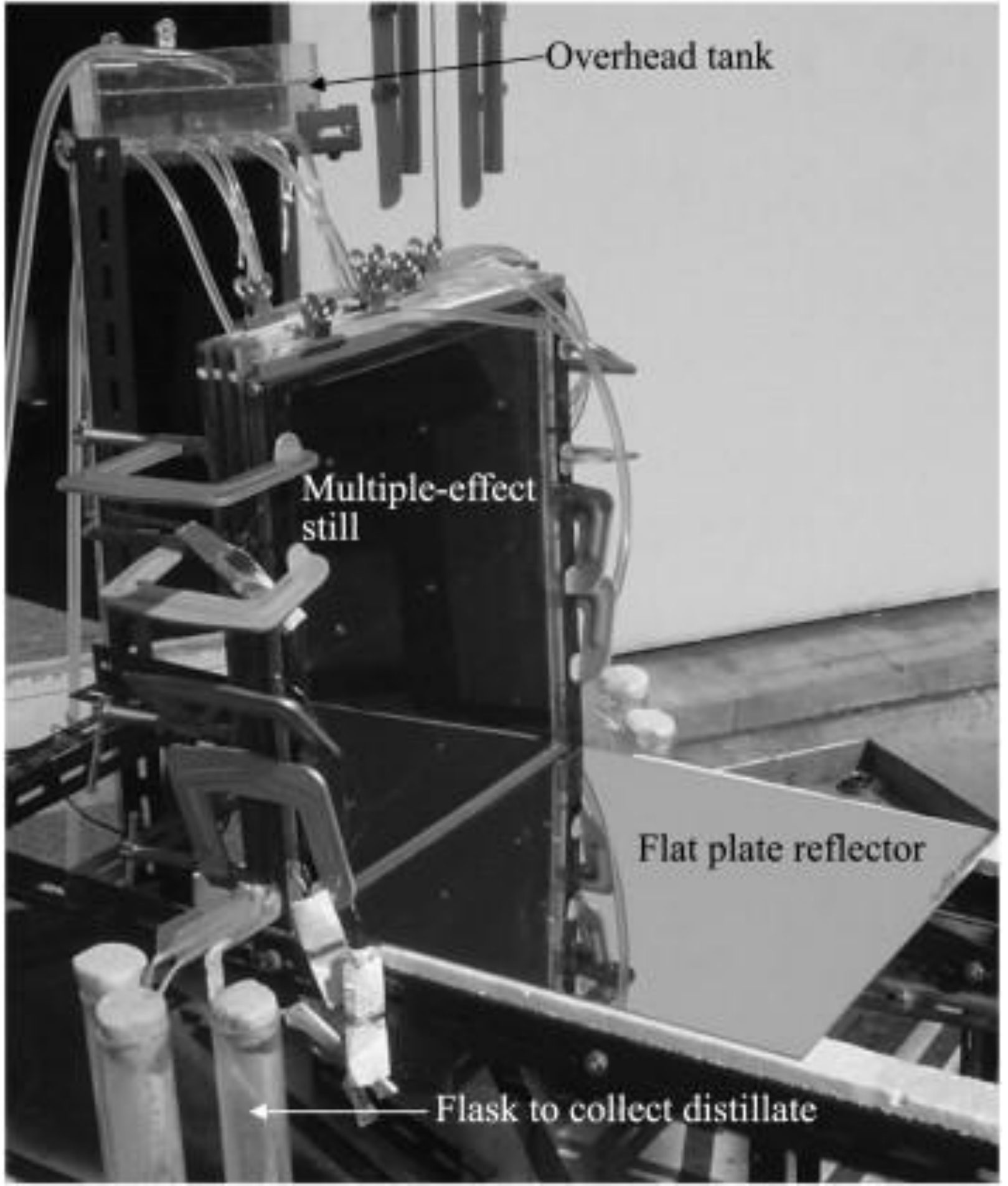

Fig.29 Schematic diagram of vertical solar still with reflector [90] 


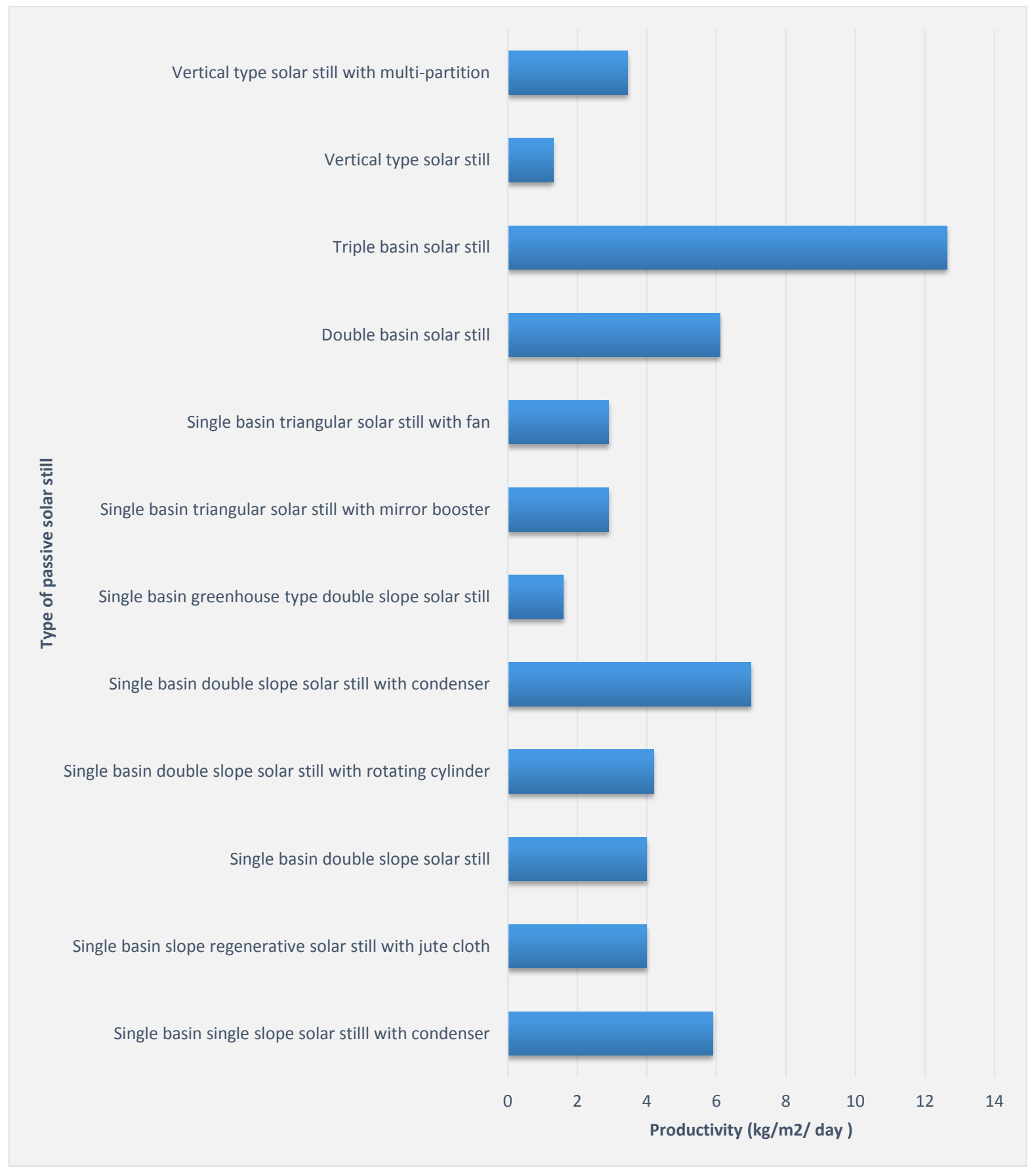

Fig.30 Productivity of various passive type solar still 


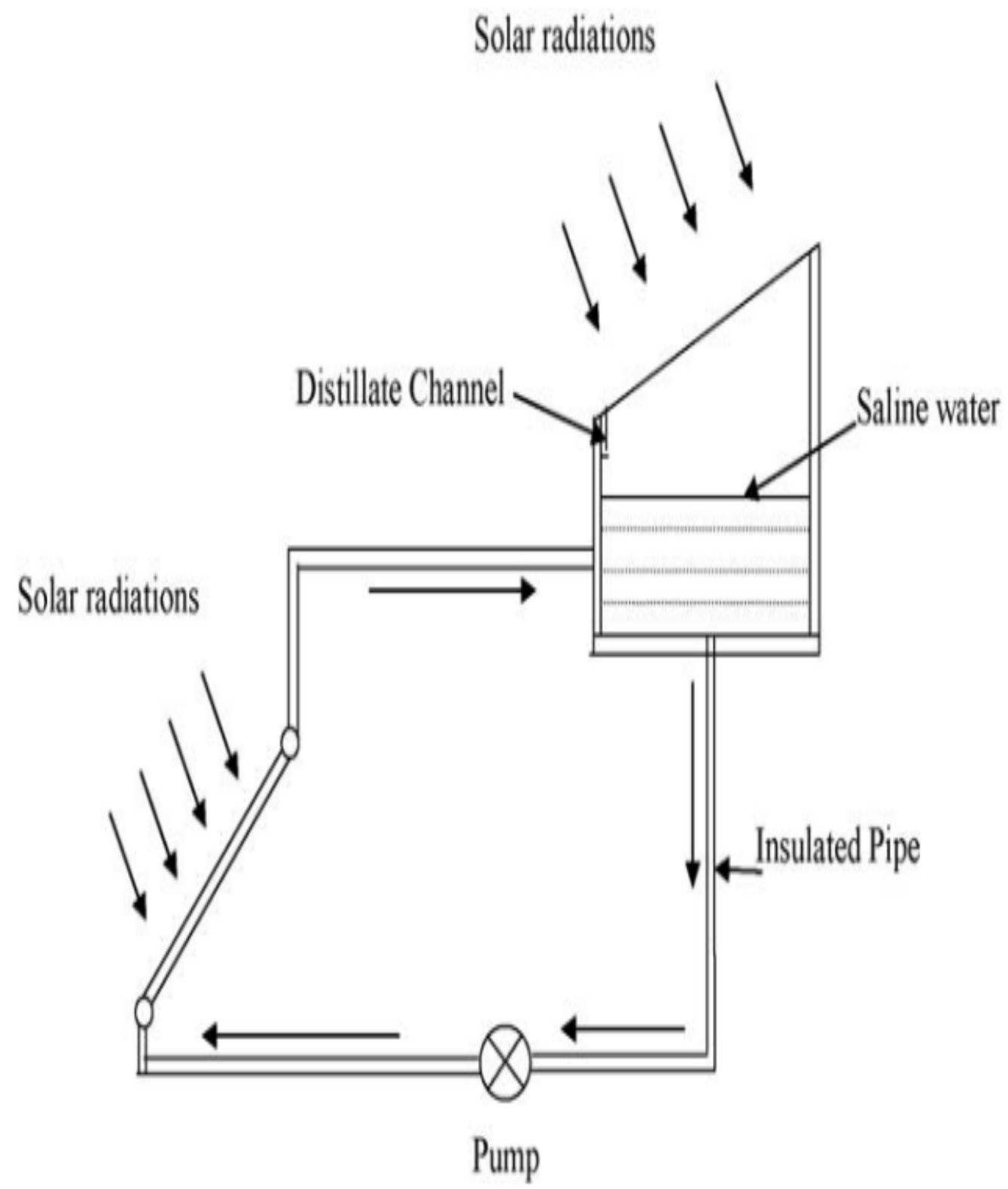

Fig.31 Schematic diagram of single basin single slope solar still with flat plate collector [109] 

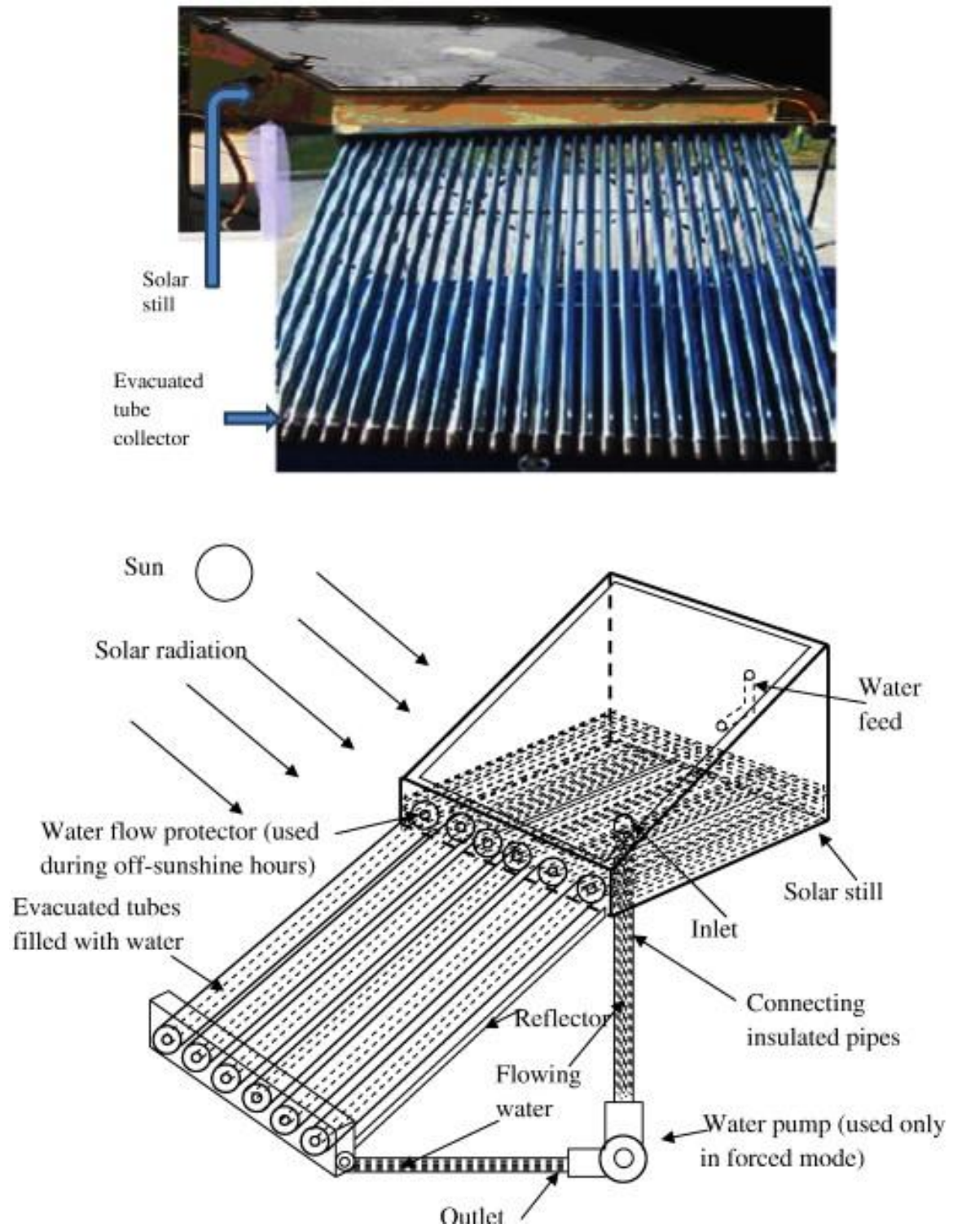

Fig.32 Schematic diagram of single basin single slope solar still with evacuated tube collector [116] 


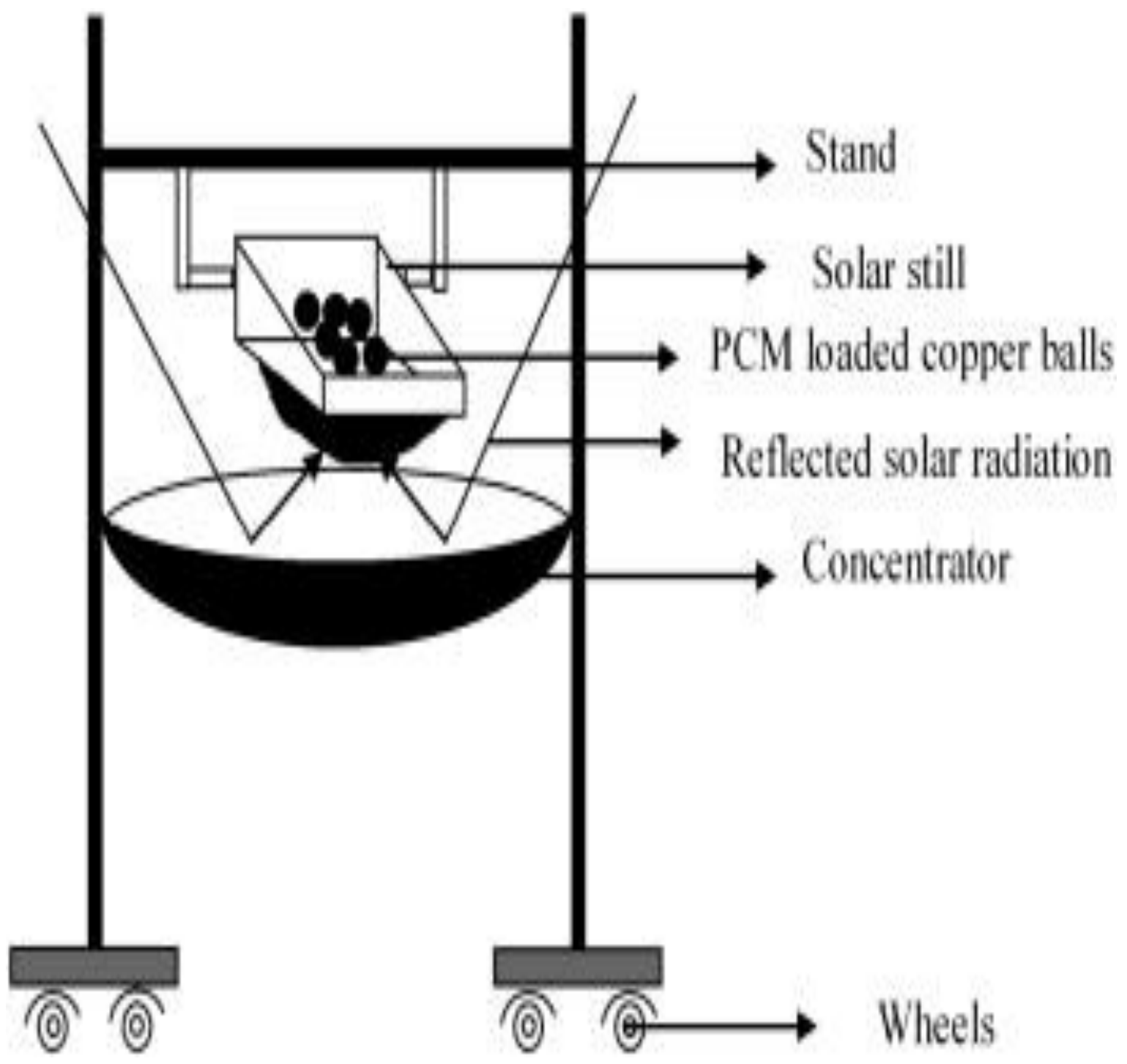

Fig.33 Schematic diagram of single basin single slope solar still with concentrator [125] 


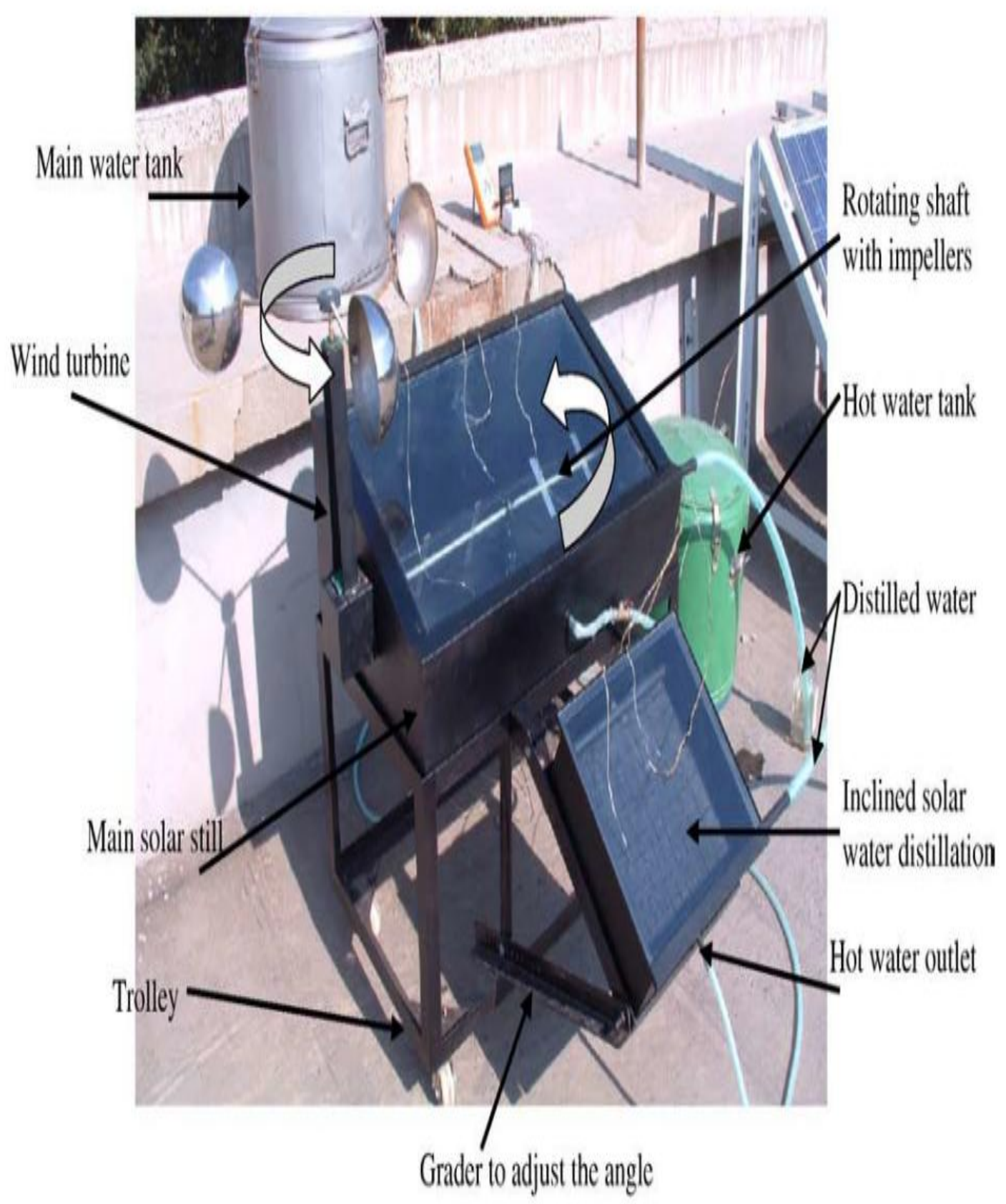

Fig.34 Schematic diagram of single basin single slope solar still with wind turbine [143] 


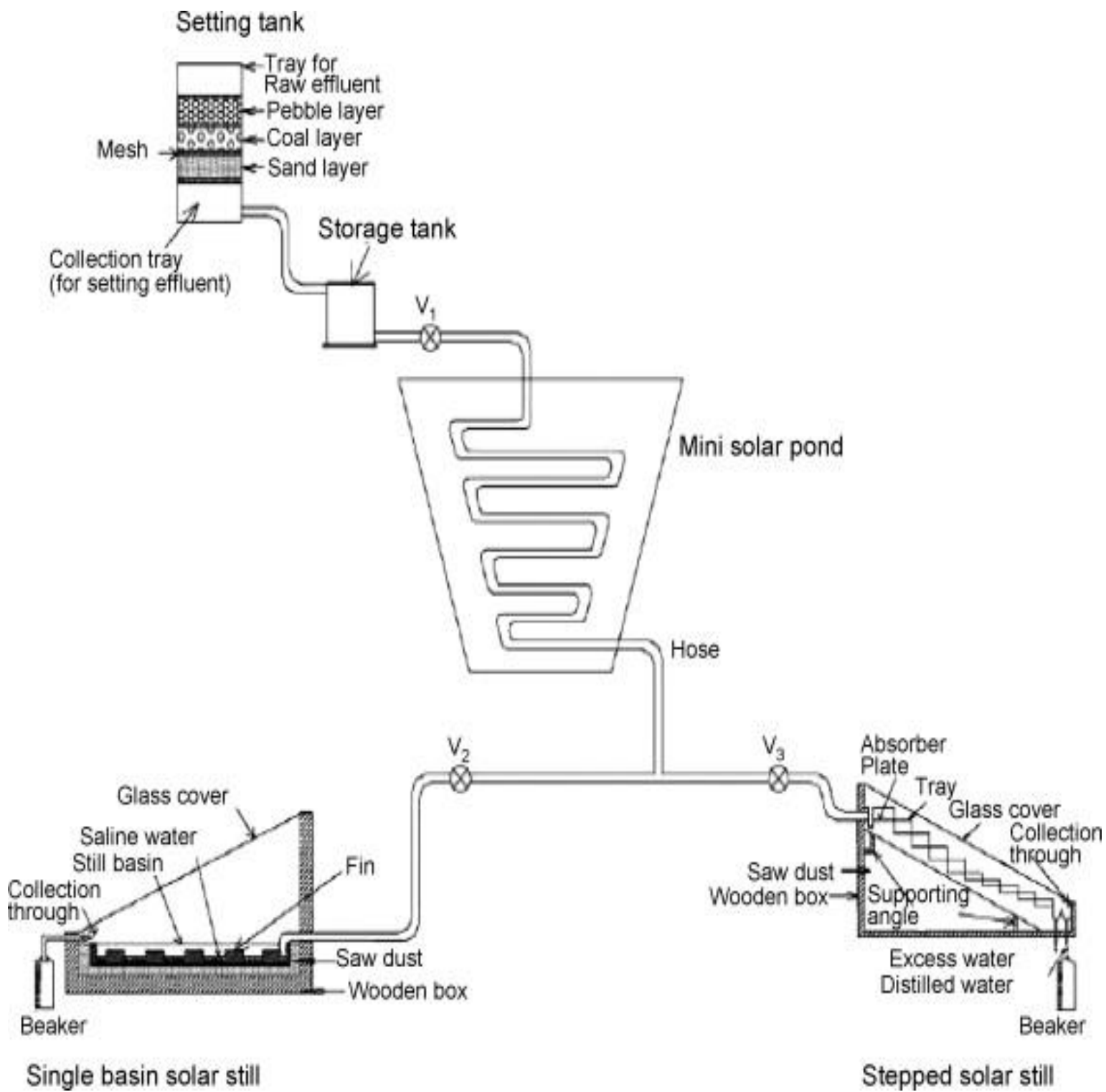

Fig.35 Schematic diagram of solar still with solar pond [118] 
Figure

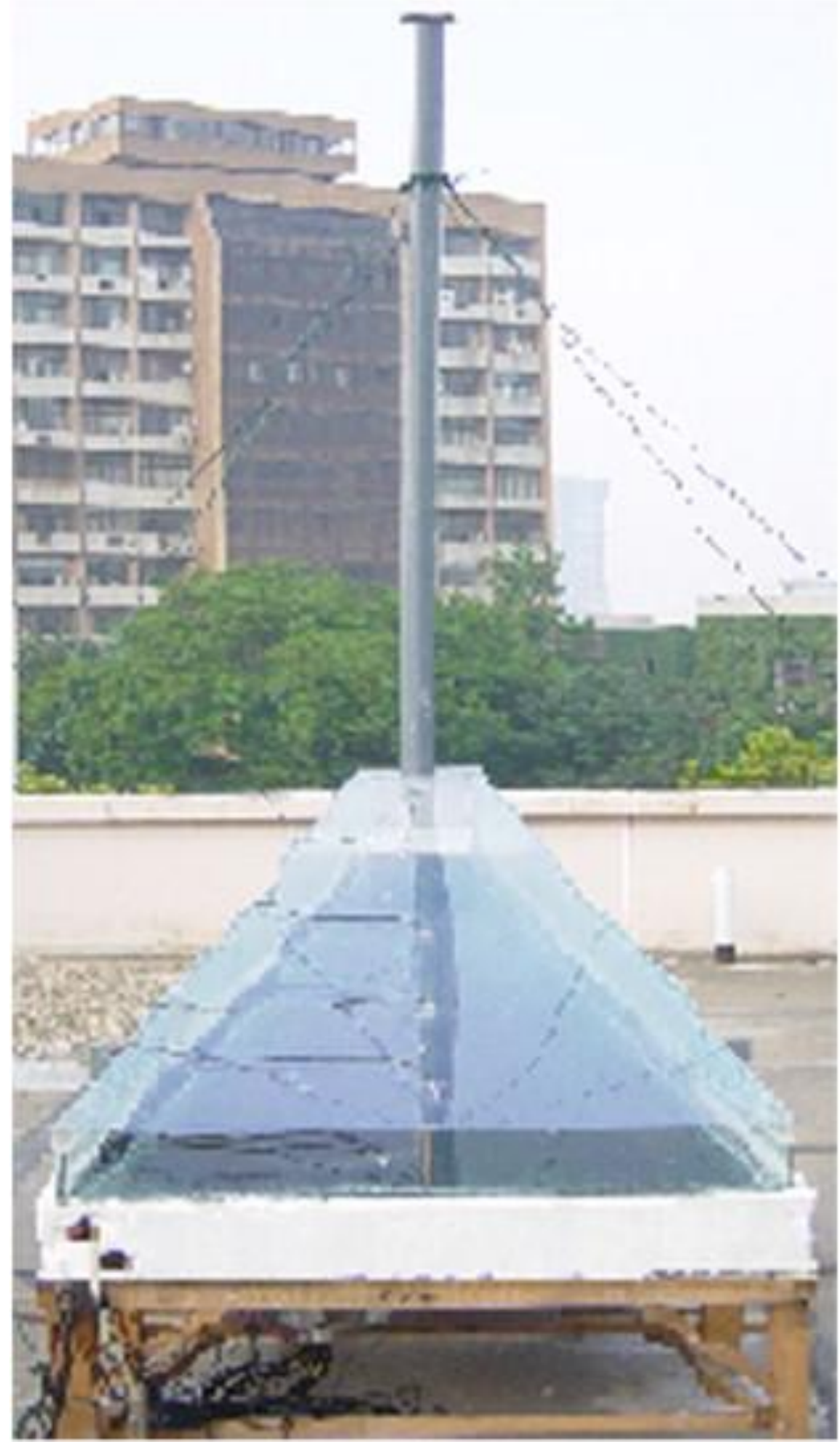

Fig.36 Schematic diagram of single basin single slope solar still with chimney [144] 


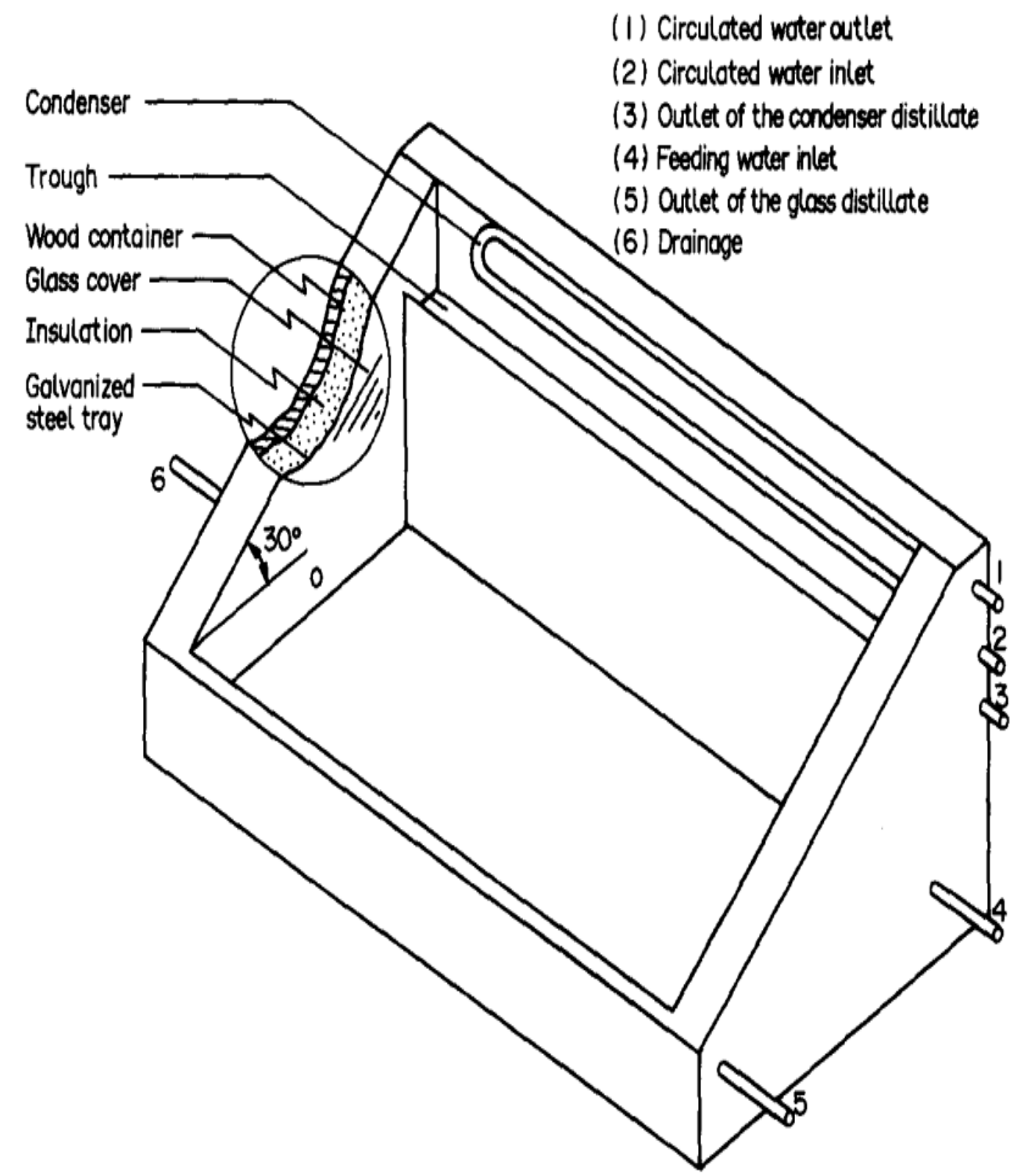

Fig.37 Schematic diagram of single basin single slope solar still with internal condenser [131] 


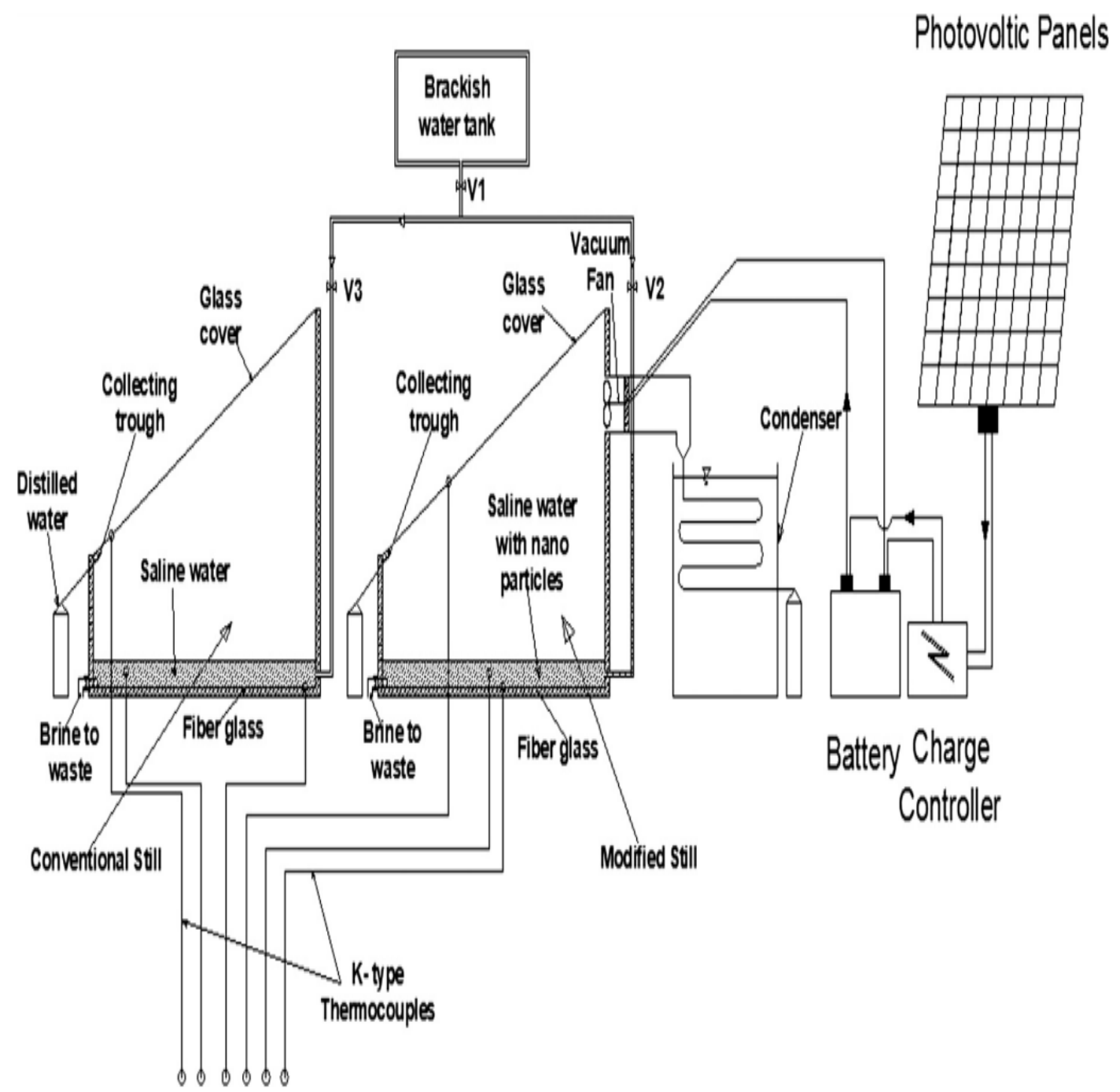

Fig.38 Schematic diagram of single basin single slope solar still with external condenser [135] 


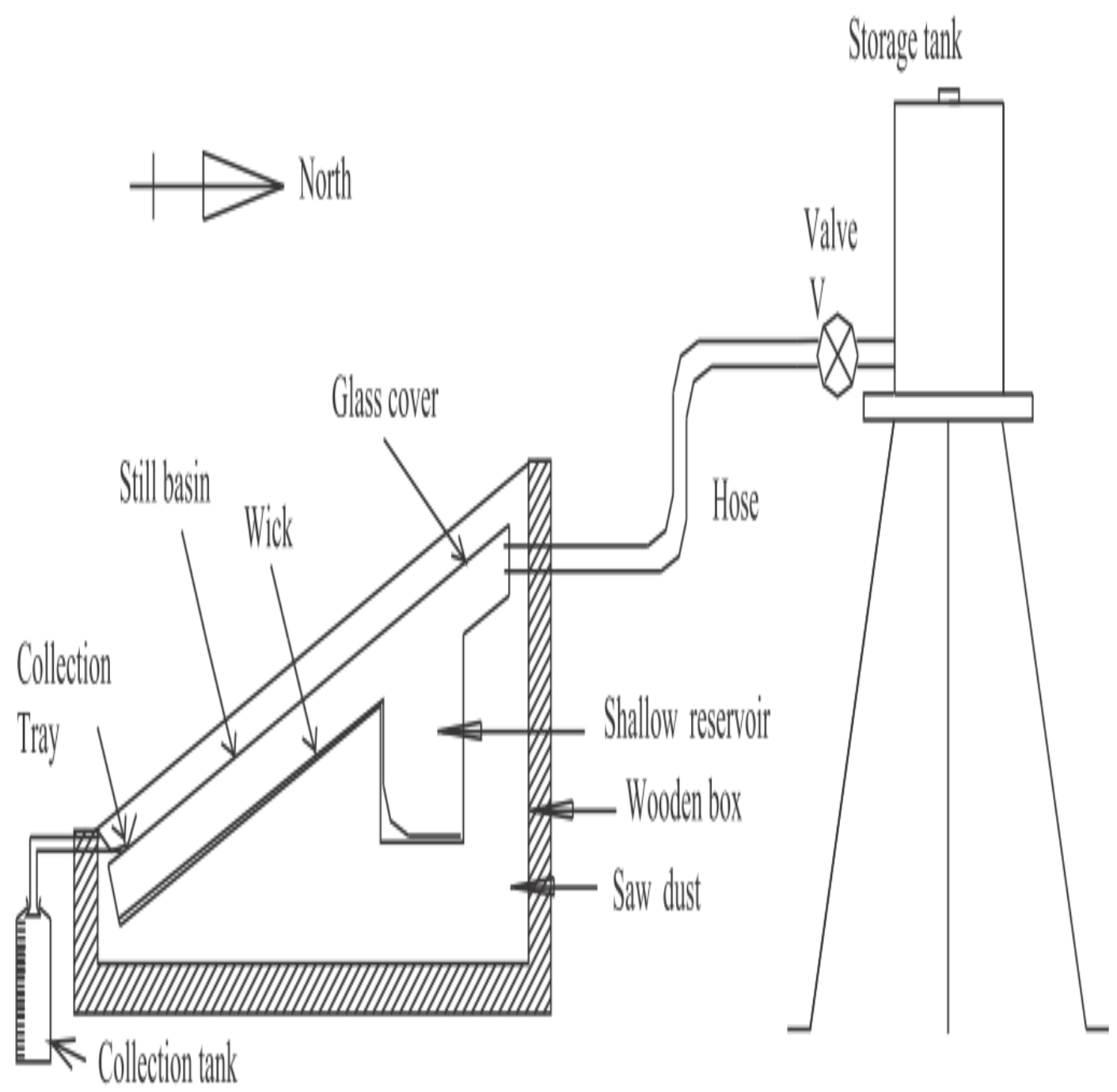

Fig.39 Schematic diagram of single basin single slope wick type solar still [150] 


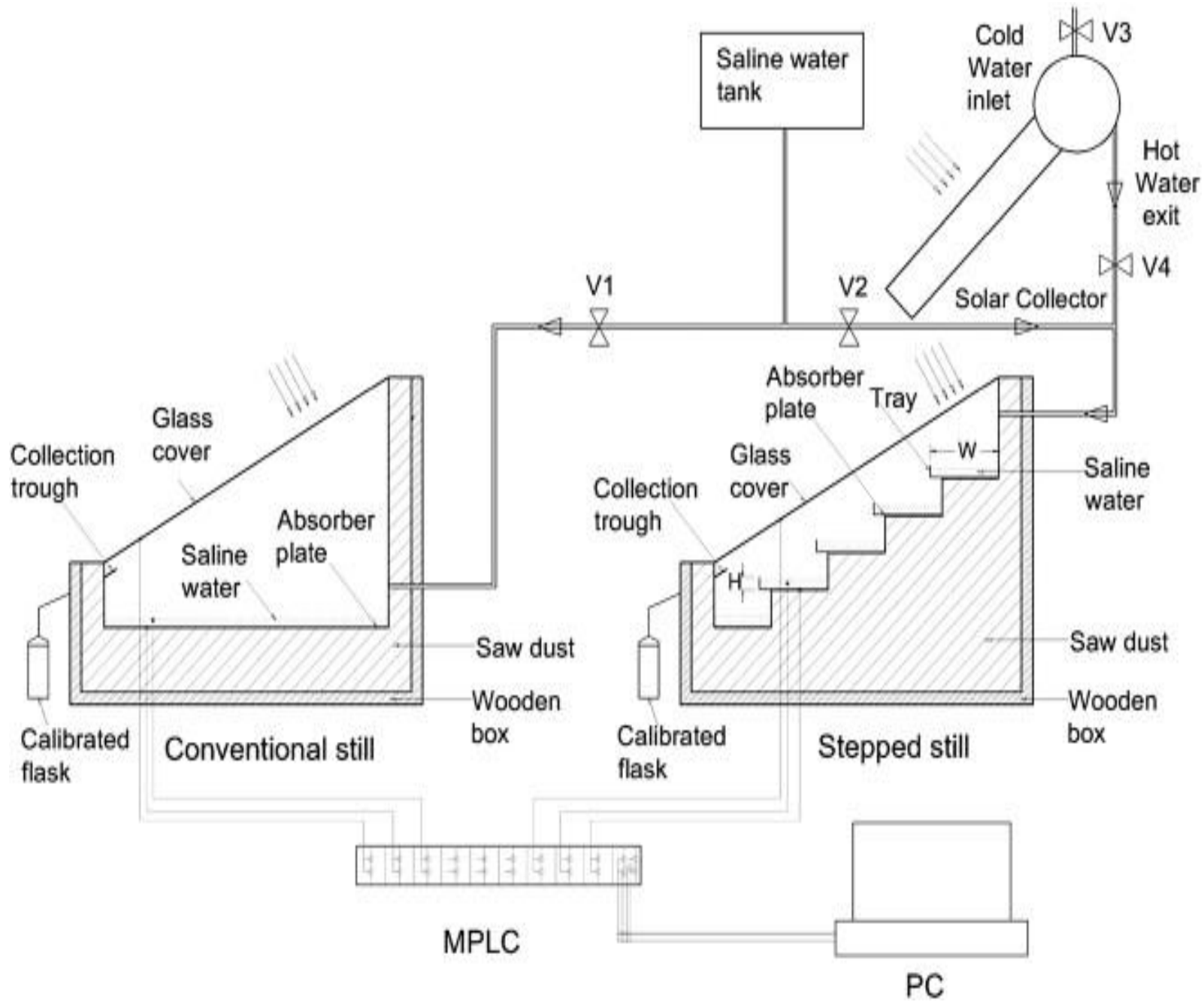

Fig.40 Schematic diagram of single basin single slope stepped solar still with collector [110] 


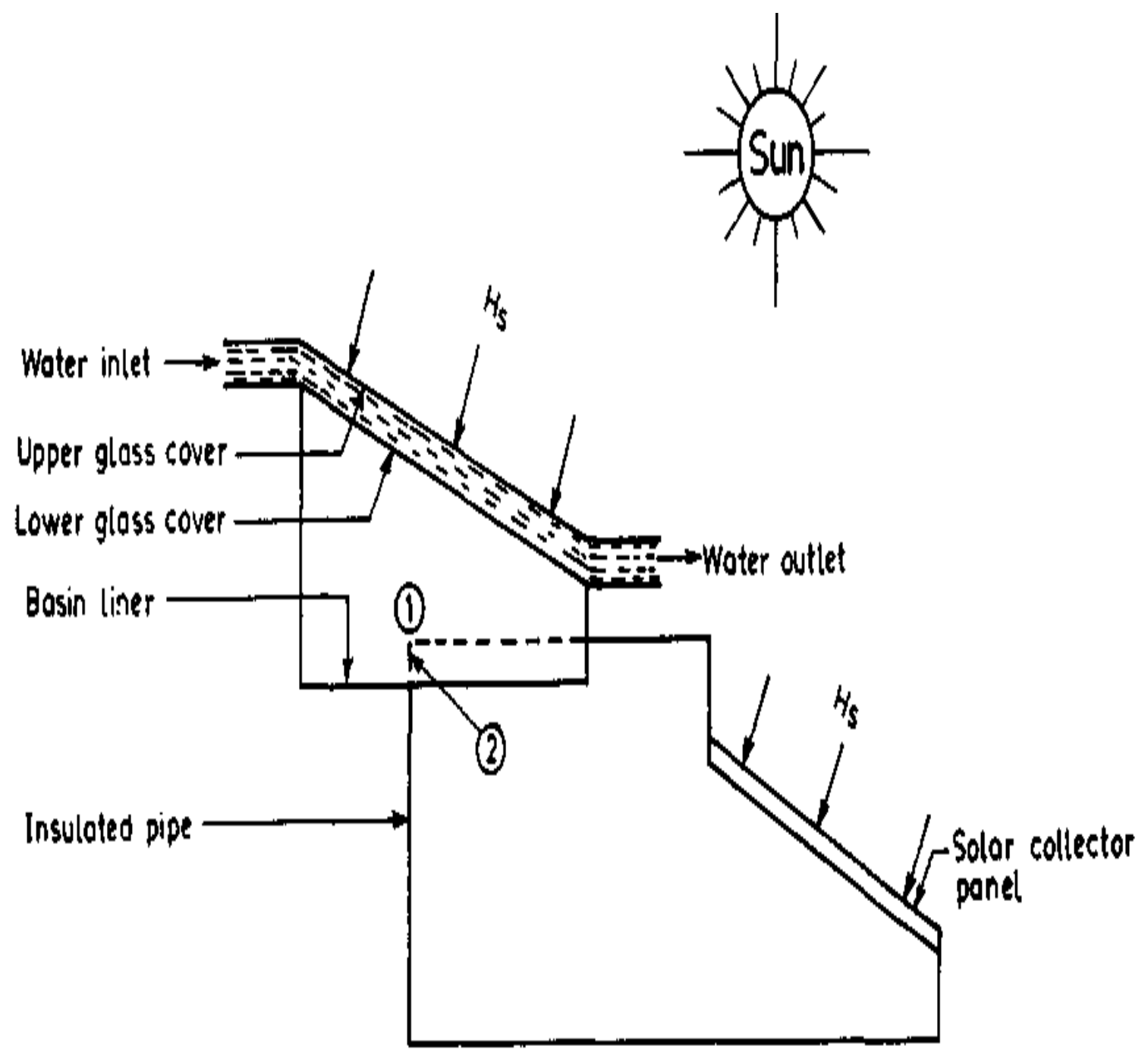

Fig.41 Schematic diagram of single basin single slope regenerative solar still [140] 
Figure

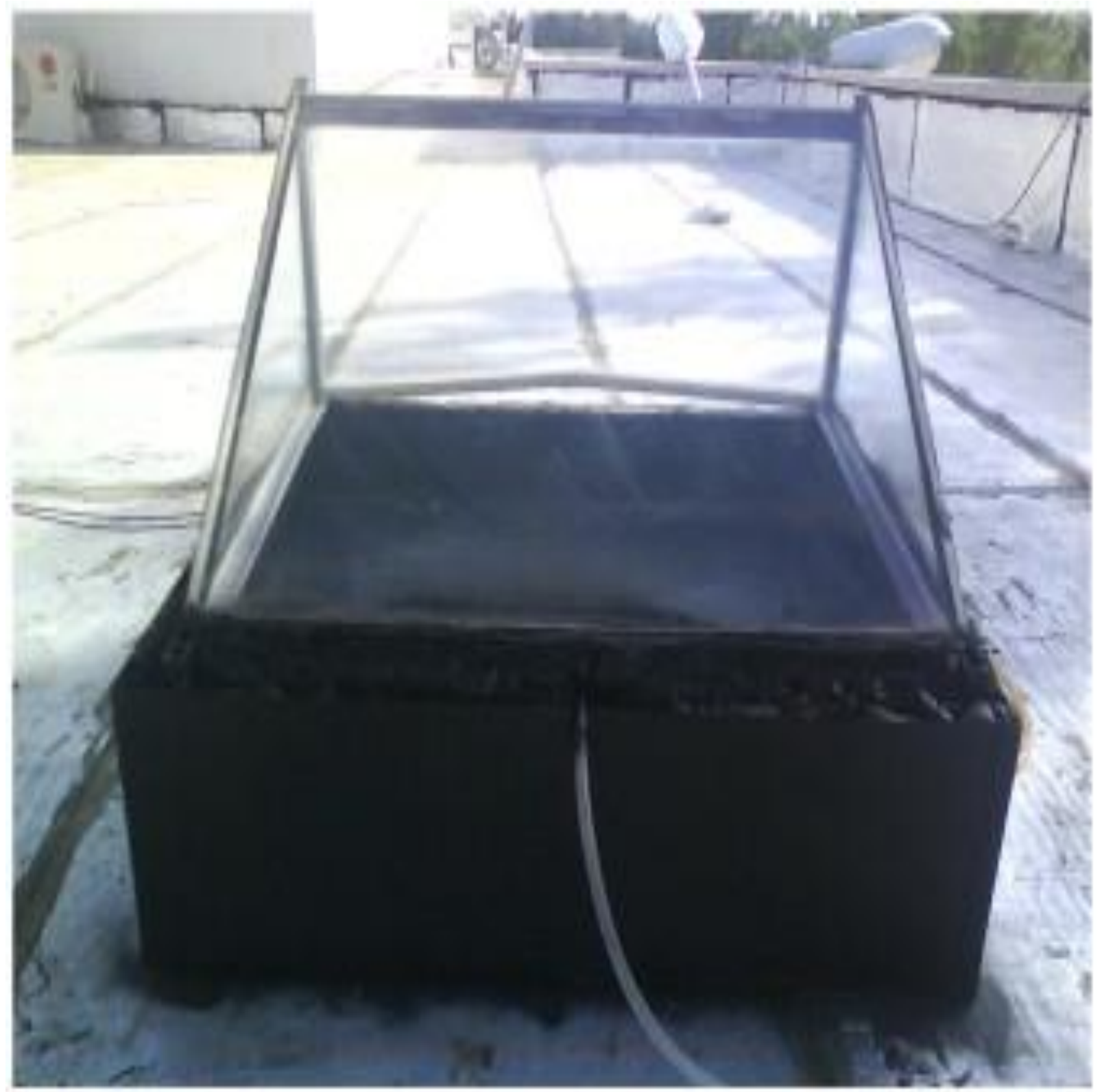

Fig.42 Schematic diagram of single basin double slope solar still [127] 
Figure

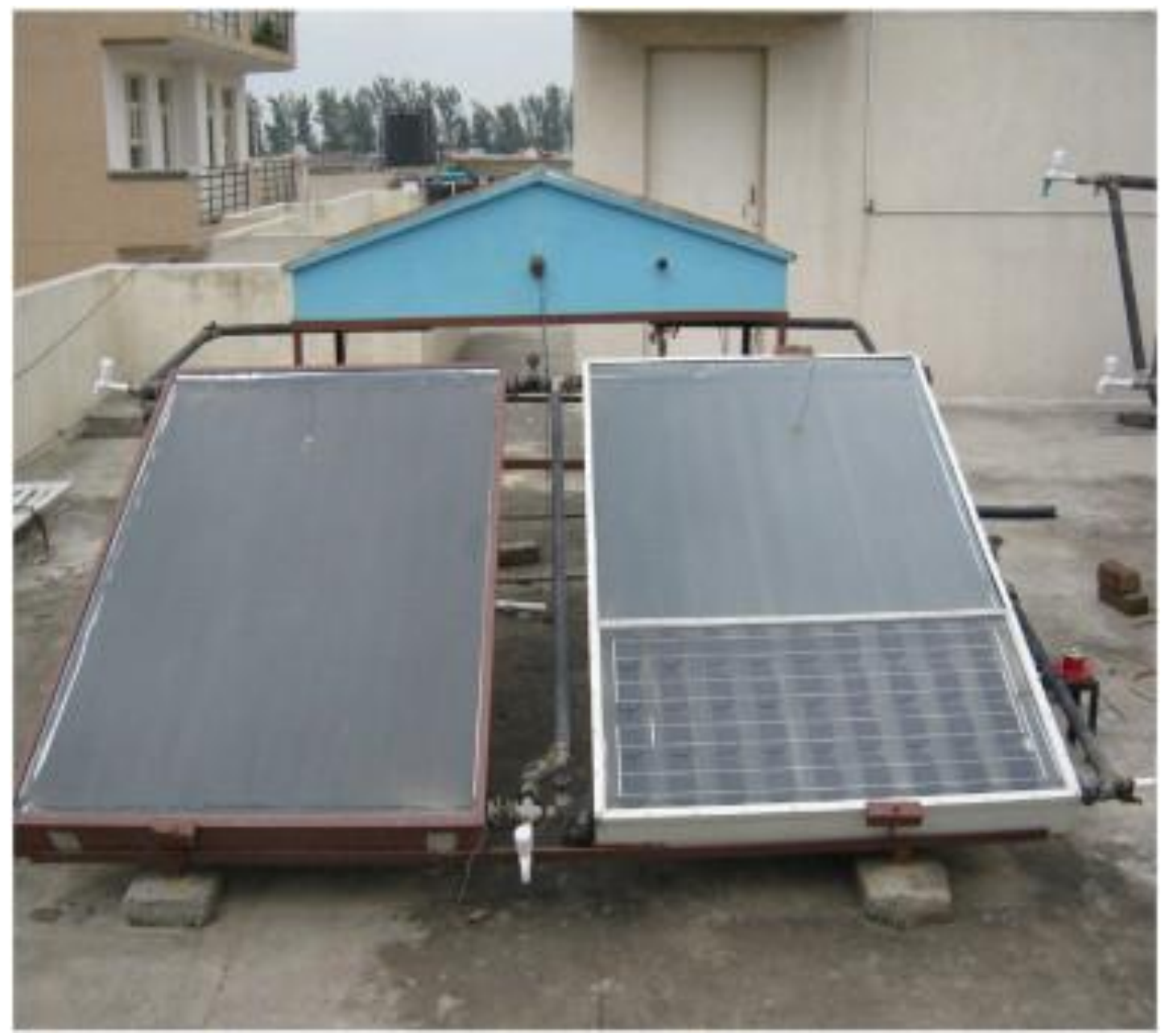

Fig.43 Schematic diagram of single basin double slope hybrid solar still [149] 
Figure

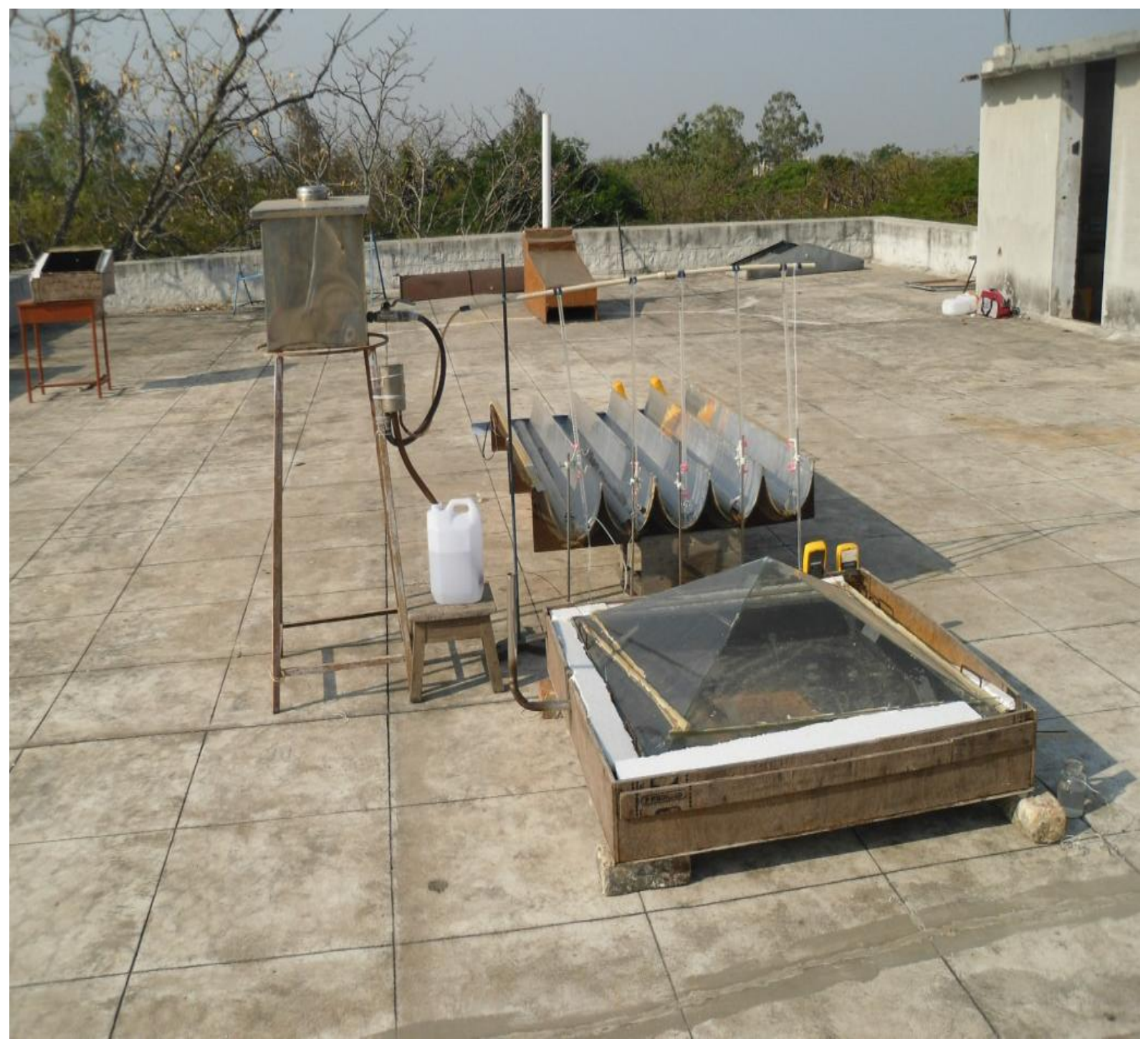

Fig.44 Schematic diagram of single basin triple slope solar still [124] 
Figure

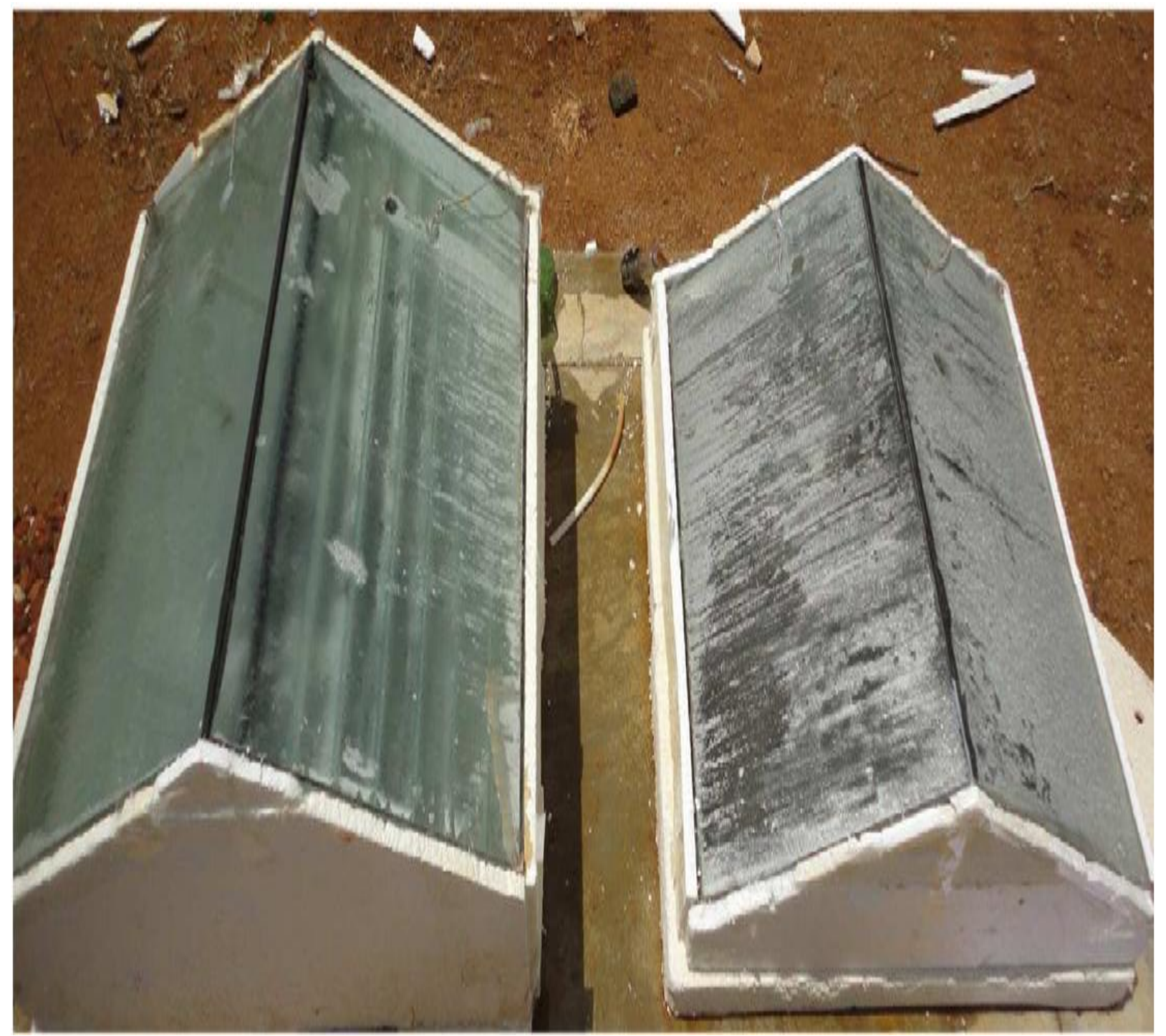

Fig.45 Schematic diagram of double basin double slope solar still [151] 
Figure

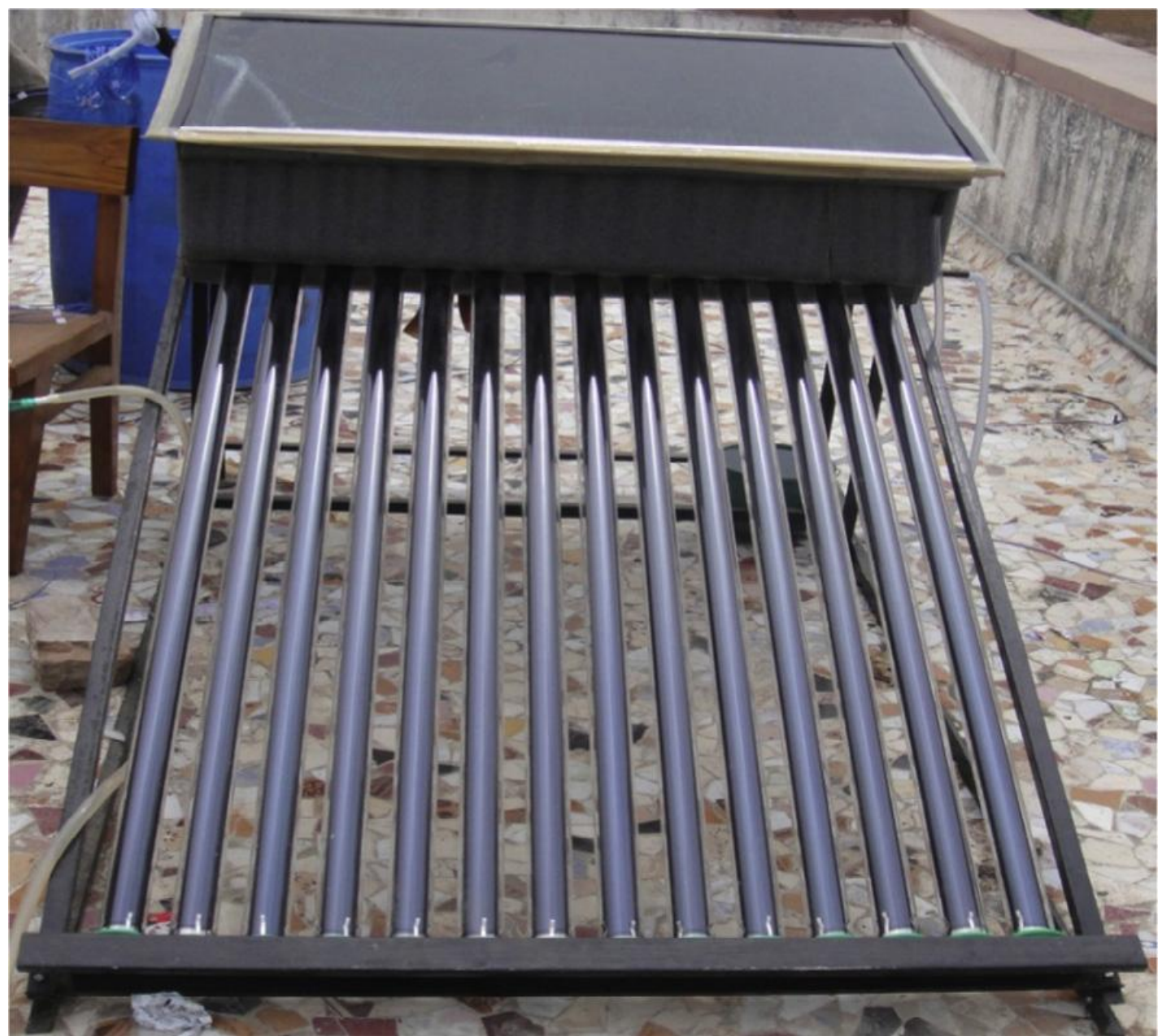

Fig.46 Schematic diagram of double basin double slope solar still with vacuum tubes [152] 


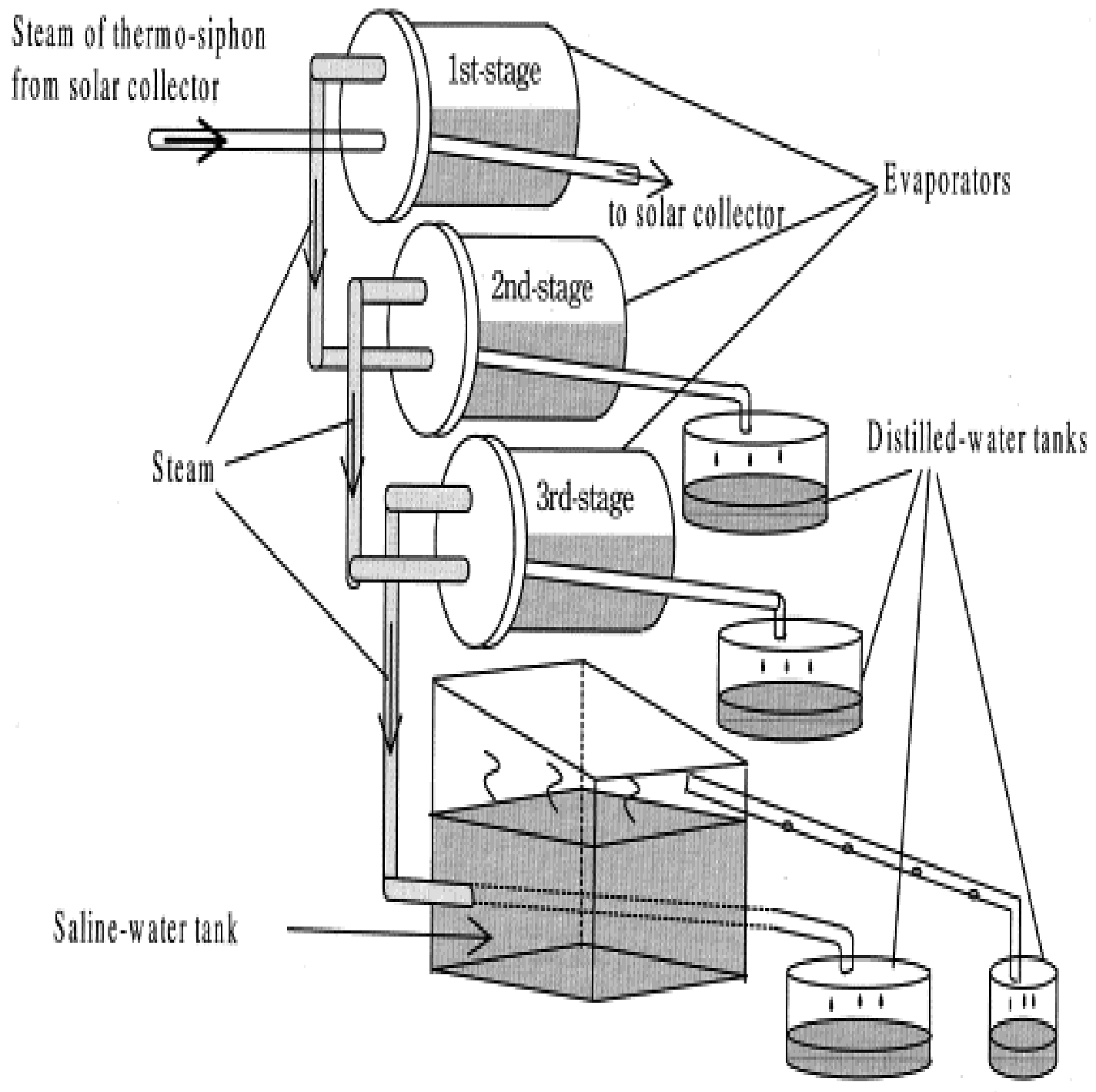

Fig.47 Schematic diagram of multi-stage solar still [153] 


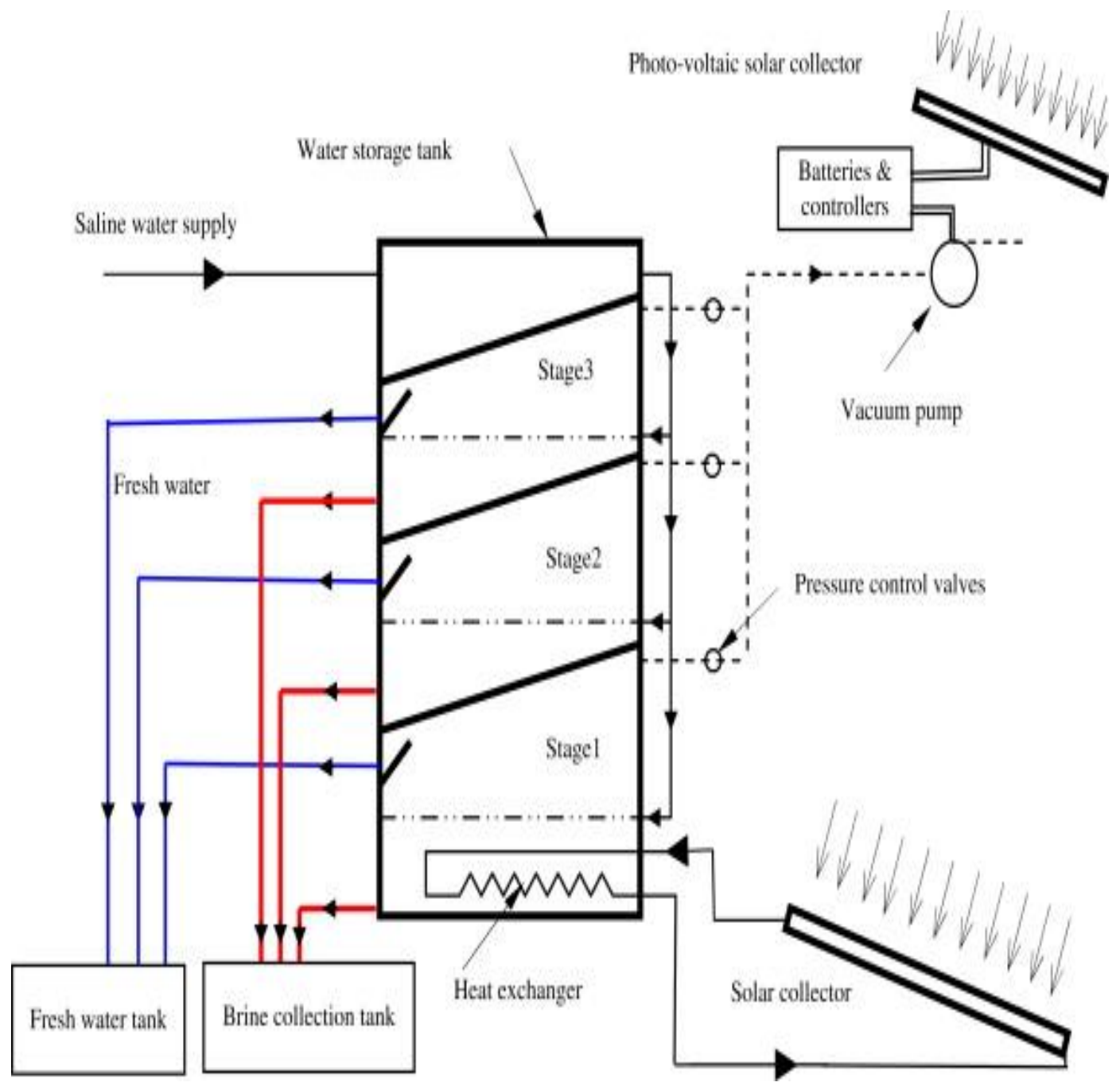

Fig.48 Schematic diagram of evacuated multi-stage solar still [154] 
Figure

solar still with mini solar pond

Single basin single slope solar still with solar heater

Slopped basin with built-in condenser

Hemispherical basin with phase change materia

Single basin single slope solar still with concentrator

Single basin single slope solar still with external condenser

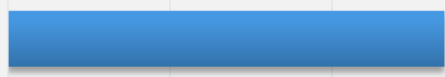

Single basin single slope solar still with passive hot water sprayed circulation

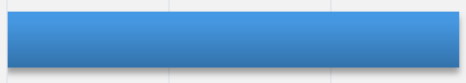

Single basin single slope solar still with active hot water sprayed circulation

Single basin single slope solar still with fixed mirror coupled with flat plate collector

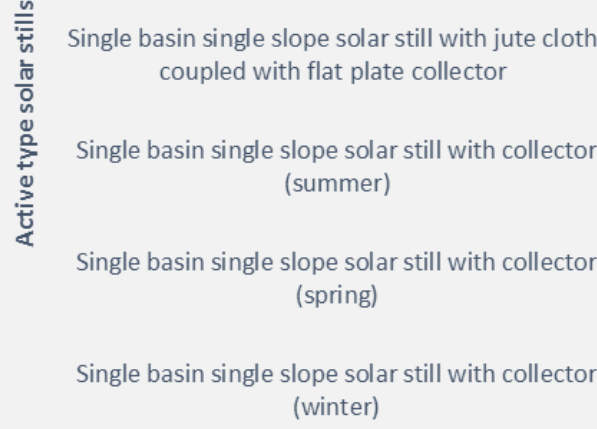
coupled with flat plate collector

Single basin single slope solar still with collector (summer)

Single basin single slope solar still with collector (spring)

Single basin single slope solar still with collector (winter)

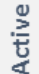
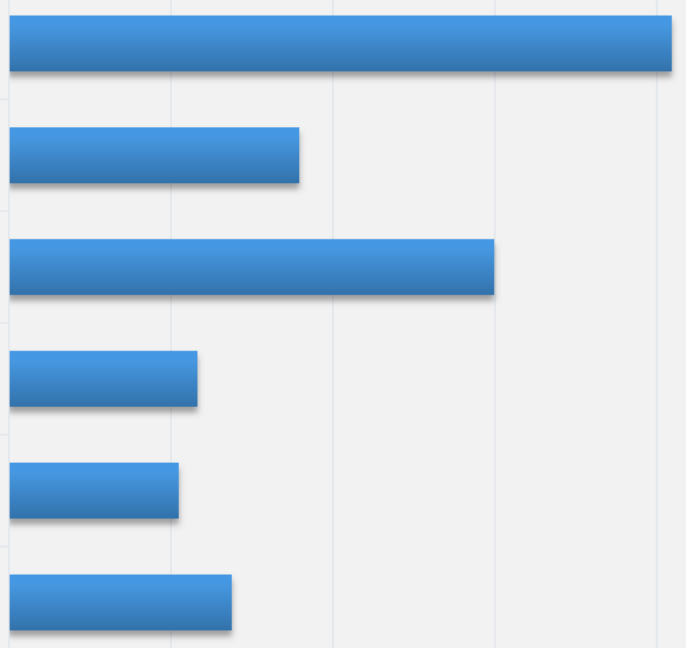


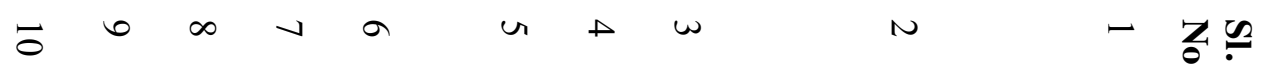

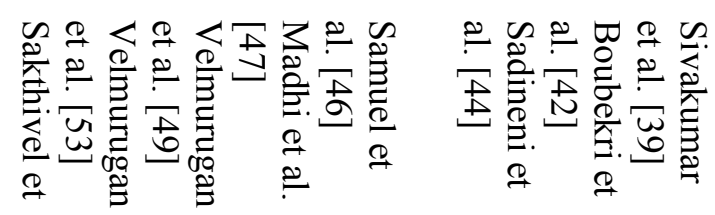

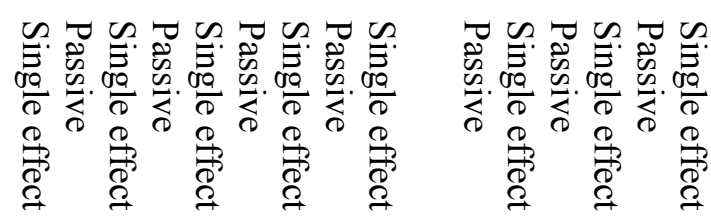

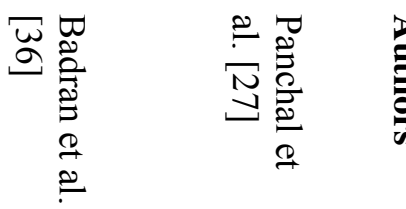

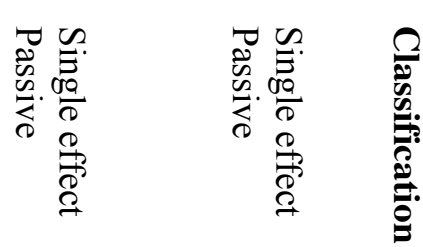

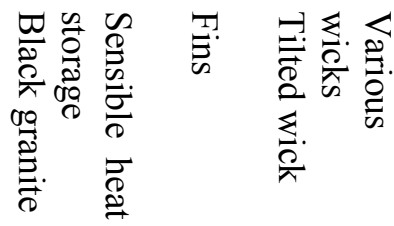

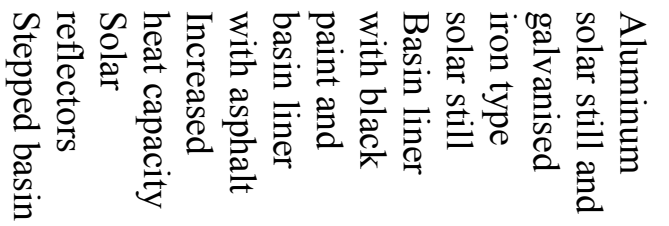

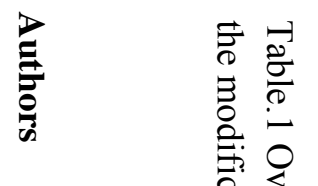

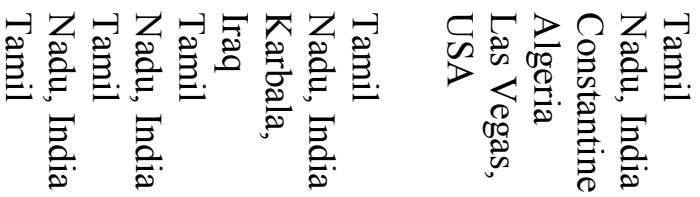

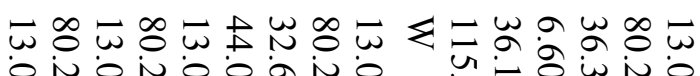

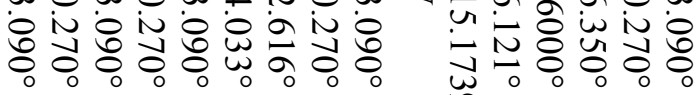

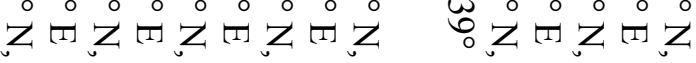

$\stackrel{\infty}{\circ} \underset{i}{\sim} \underset{w}{\sim}$

$\stackrel{N}{\sim} \underset{\infty}{\stackrel{\sim}{\circ}}$

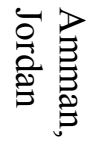

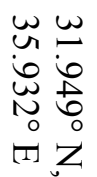

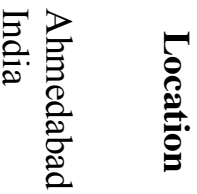

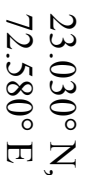

高

No

:3.:

产. $\frac{9}{3}$

产 ᄋ

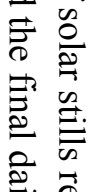

这.

융

志.

กี ซึ

․ㅗㅇ

๖

这者

苍

مै

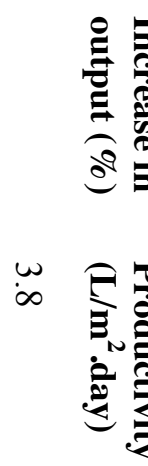

응

这.

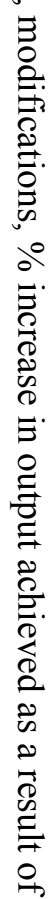

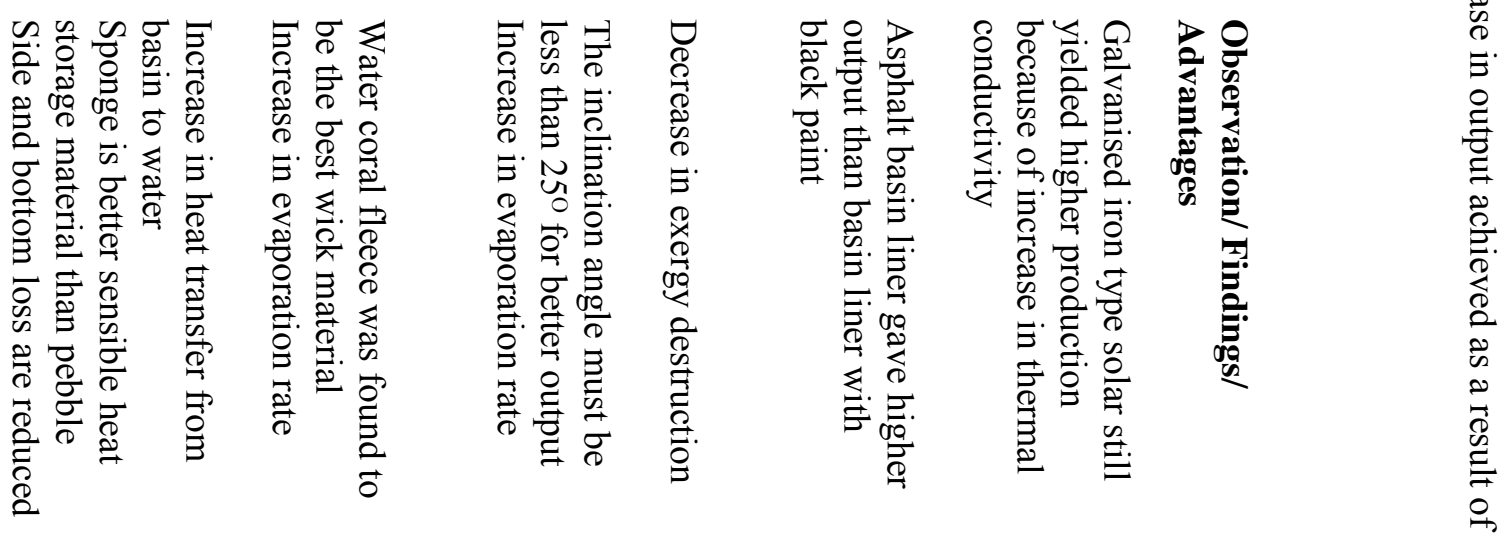




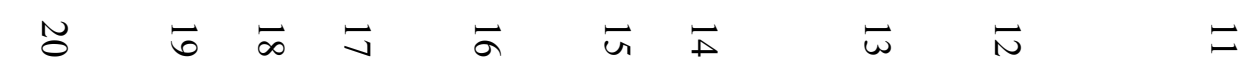

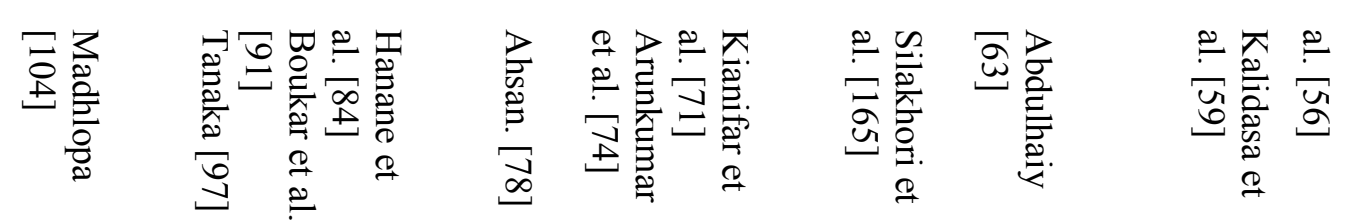

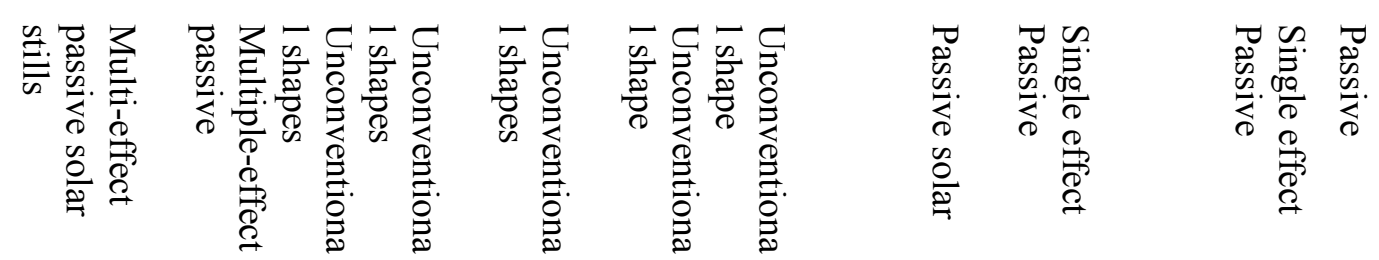

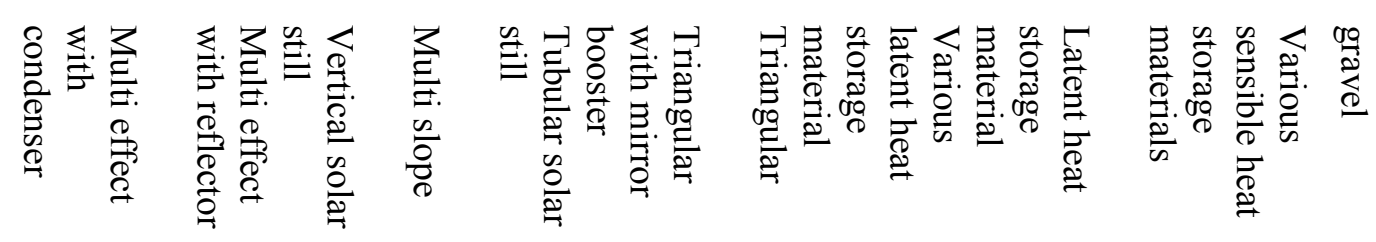

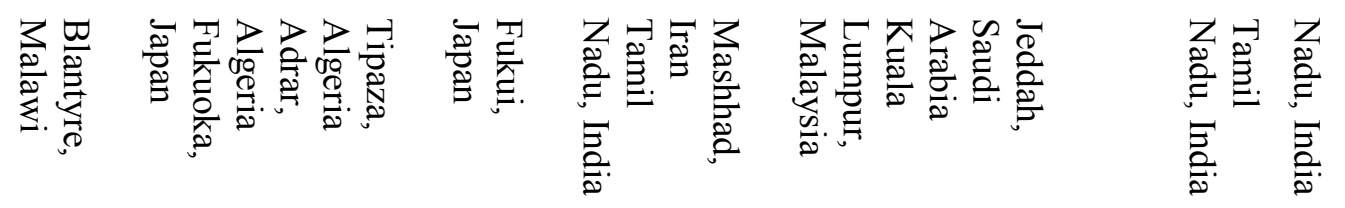

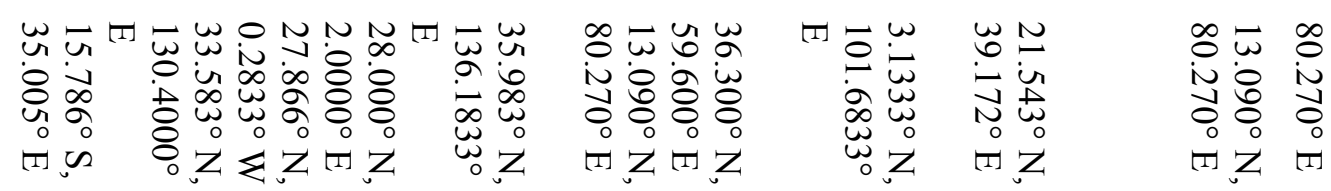

N

$\underline{\underline{\underline{a}}}$

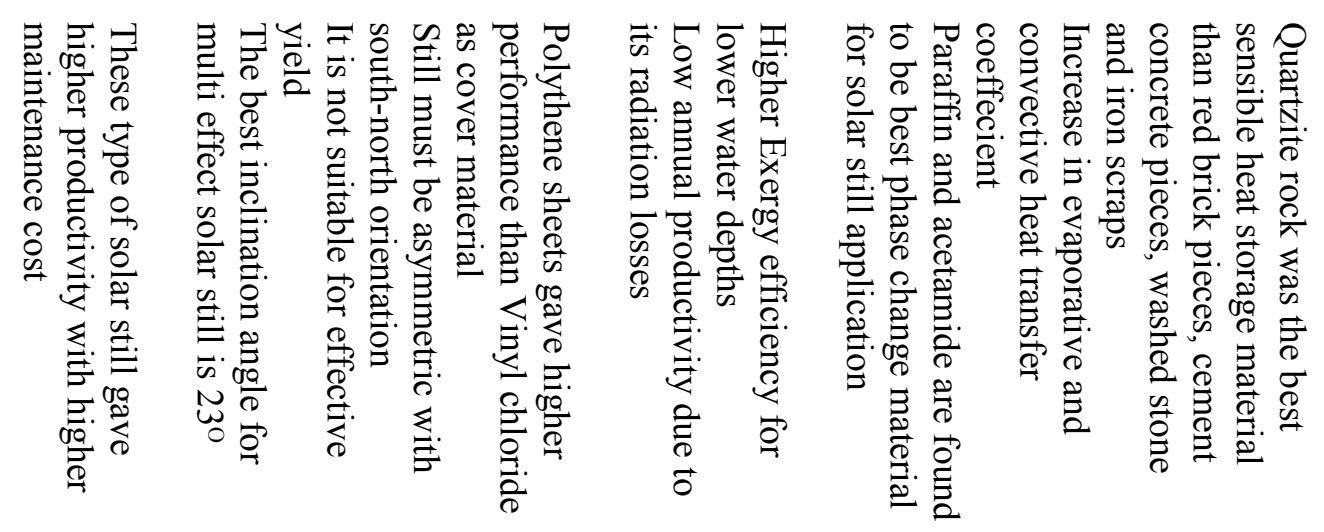




\begin{tabular}{|c|c|c|c|c|c|c|}
\hline 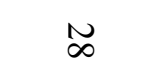 & $\mathcal{N}$ & $\tilde{\sigma}$ & $\tilde{N}$ & $\stackrel{N}{\perp}$ & N & 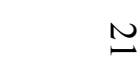 \\
\hline 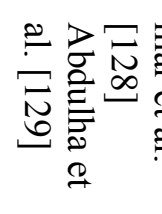 & 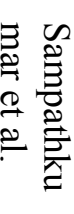 & 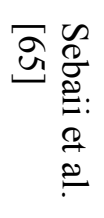 & 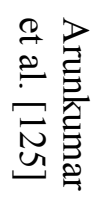 & 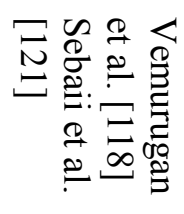 & 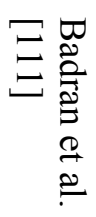 & 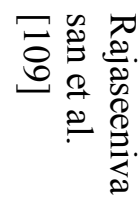 \\
\hline 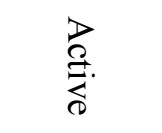 & 究. & 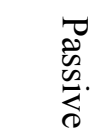 & 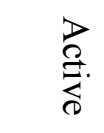 & 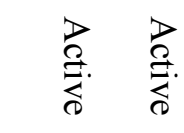 & 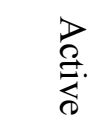 & \\
\hline
\end{tabular}

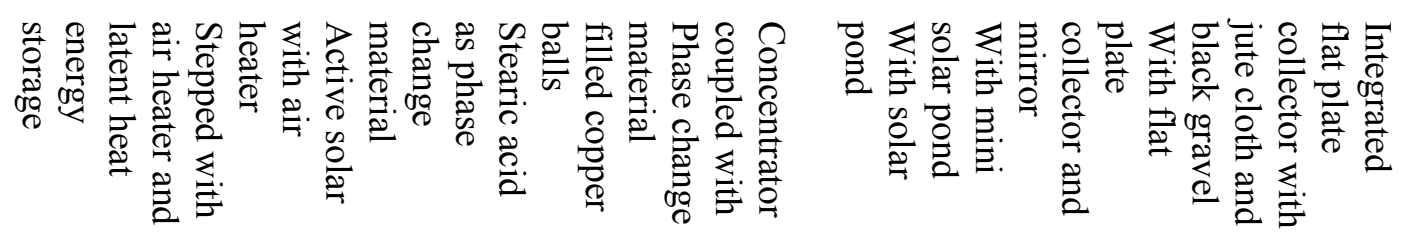

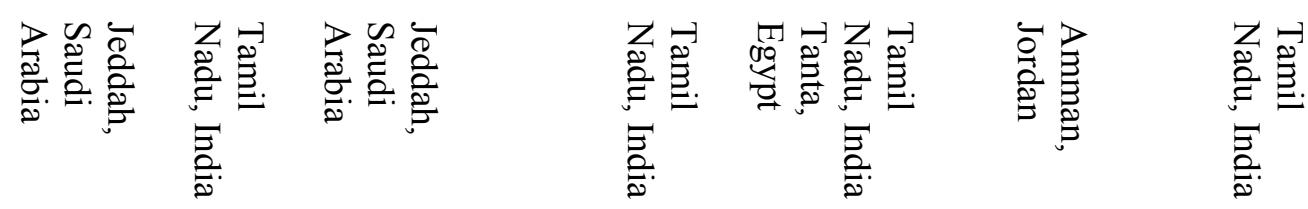

\begin{tabular}{|c|c|c|c|c|c|}
\hline 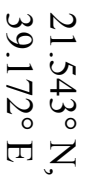 & 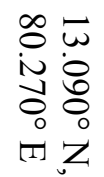 & 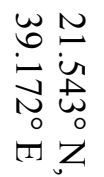 & 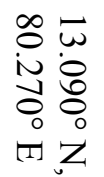 & 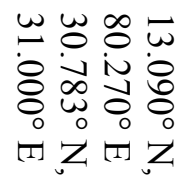 & 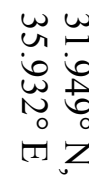 \\
\hline$\stackrel{u}{\omega}$ & d & & $\tilde{\sigma}$ & $\begin{array}{l}N \\
\dot{a}\end{array}$ & 0 \\
\hline
\end{tabular}

$\begin{array}{lllll}\dot{0} & \dot{0} & \ddot{v} & \dot{\sigma}\end{array}$

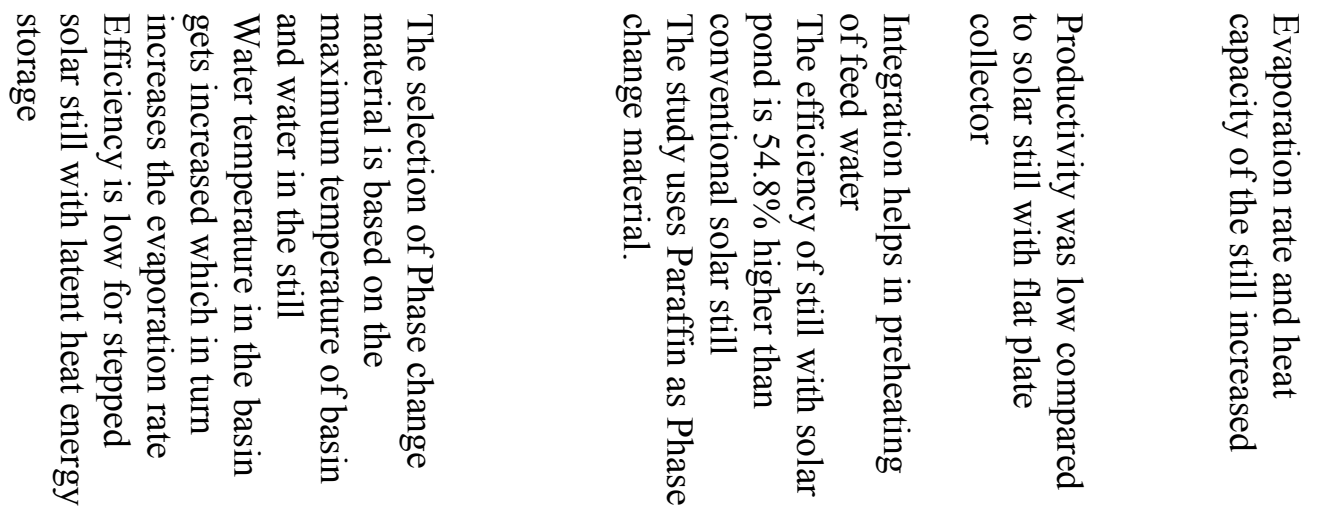




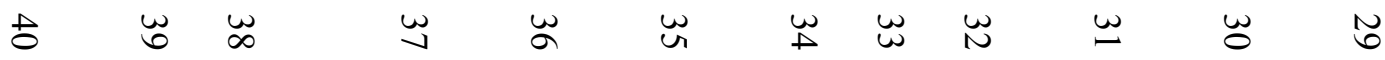

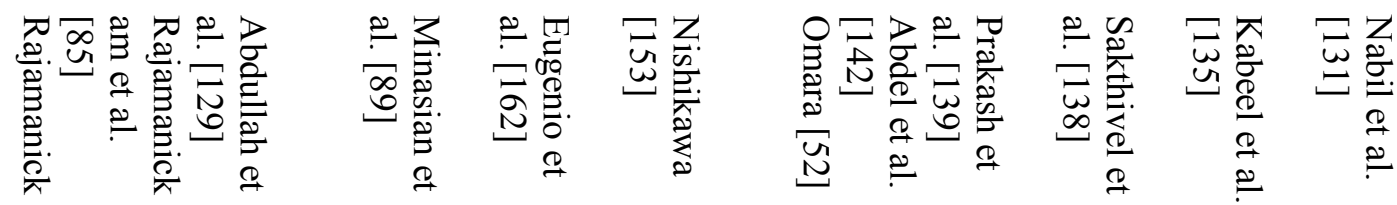

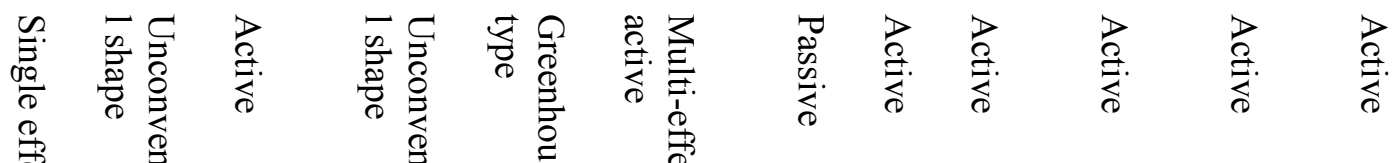

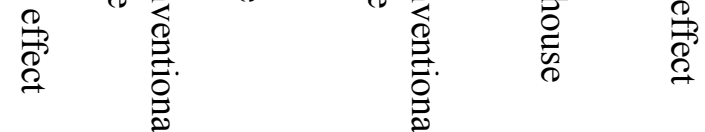

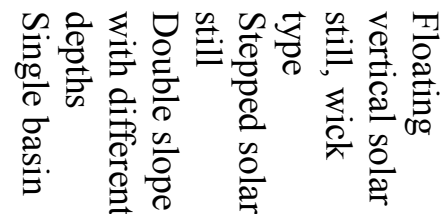

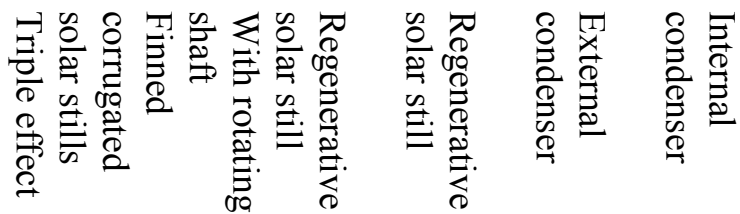

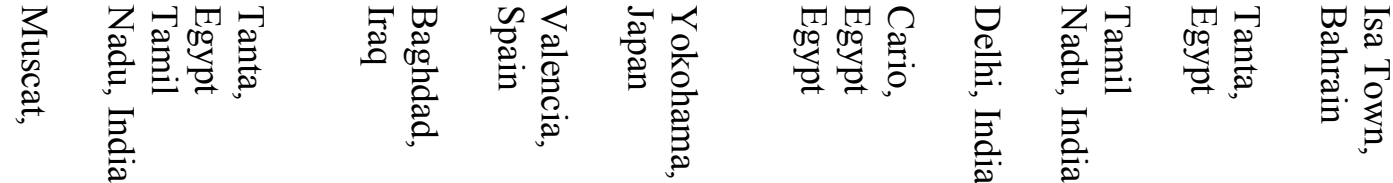

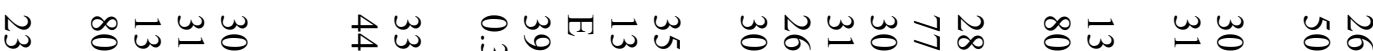

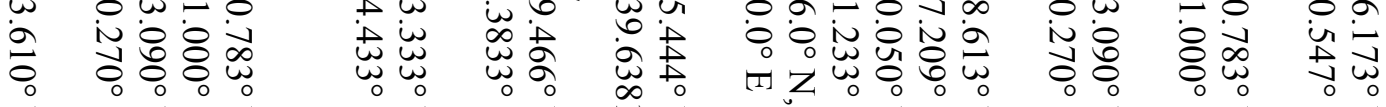

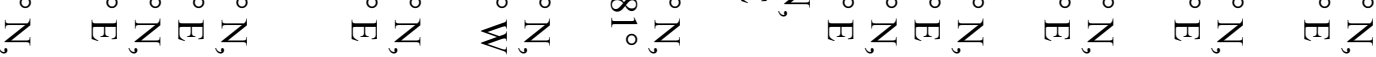

ำ

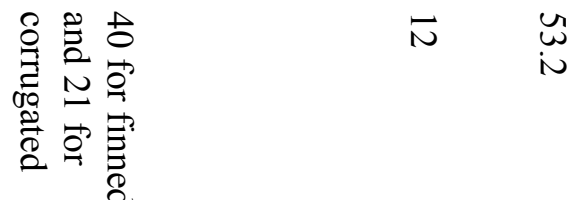

$$
\begin{aligned}
& \text { بs }
\end{aligned}
$$

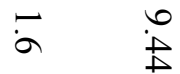

$$
\begin{aligned}
& \text { in } \quad
\end{aligned}
$$

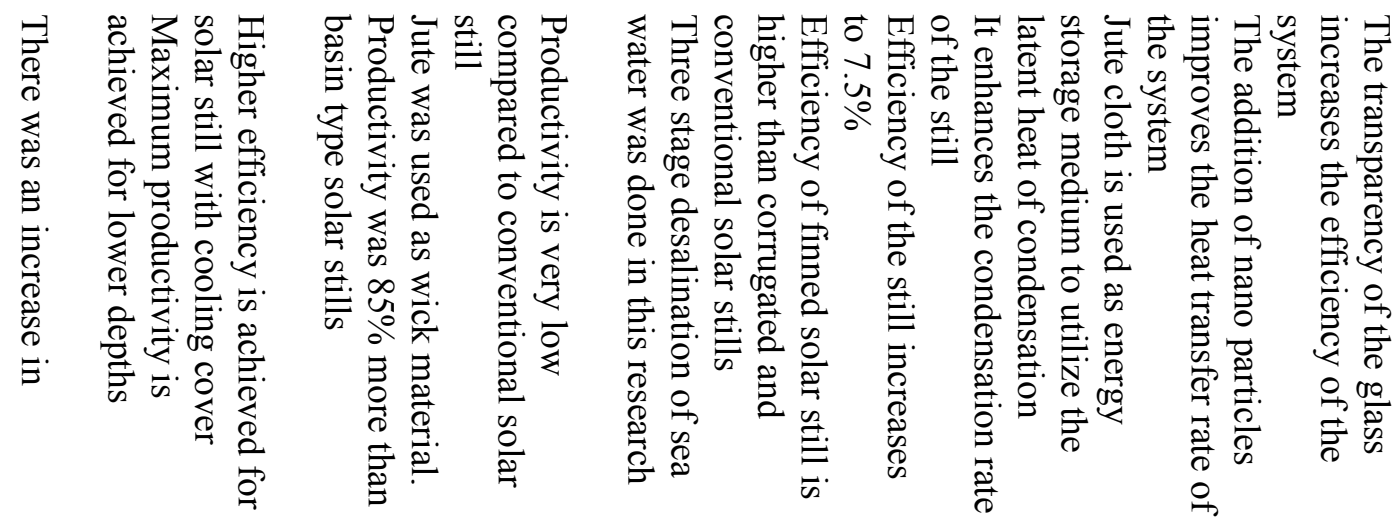




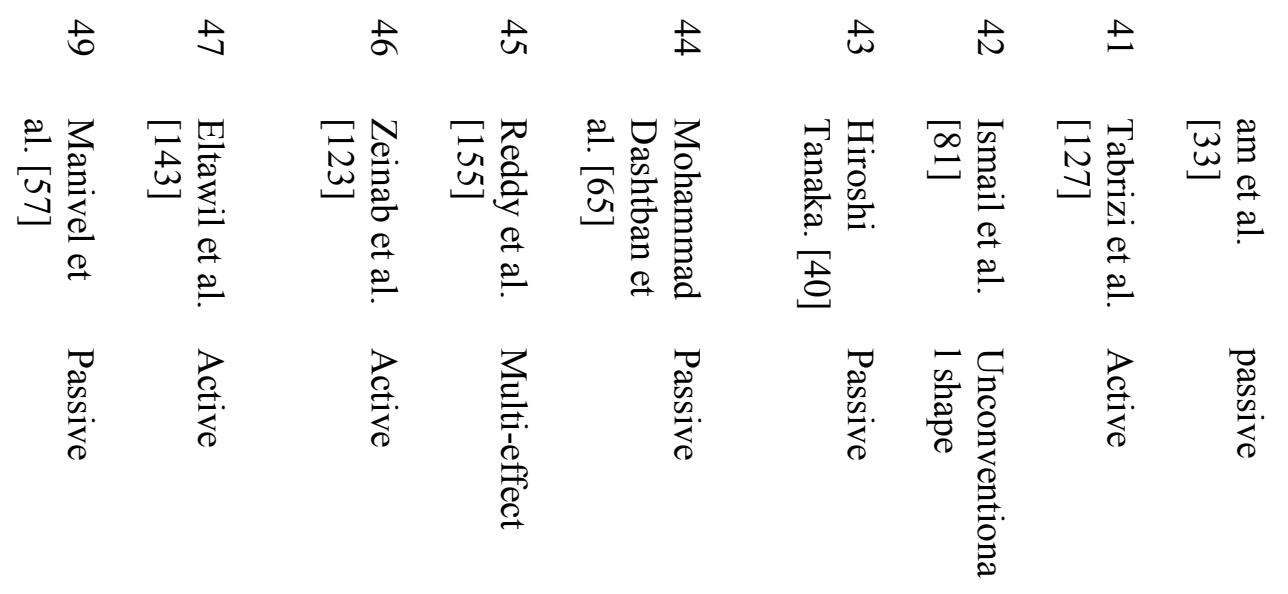

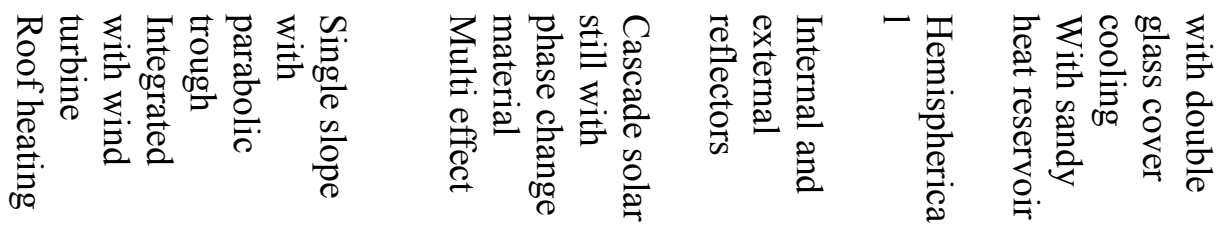

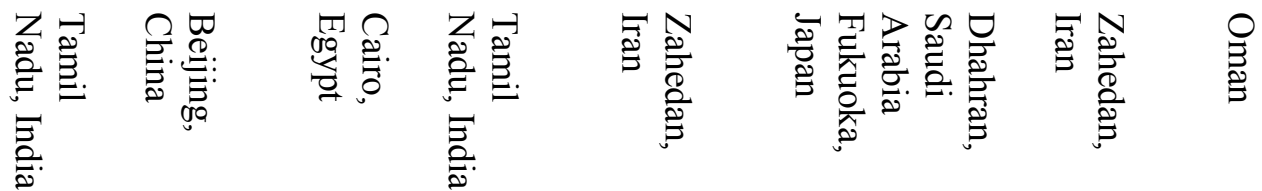

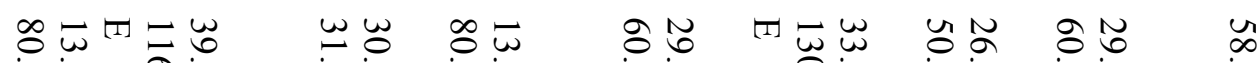

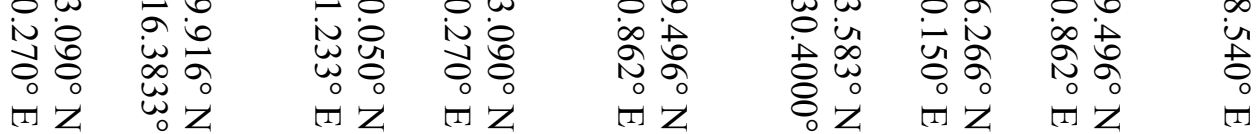

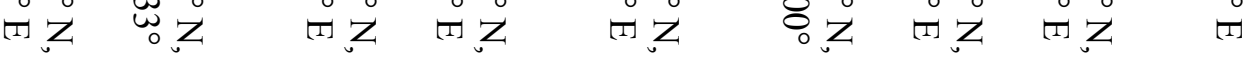
$\infty \quad \infty \quad \underset{\infty}{\infty} \quad \stackrel{+}{0^{\infty}}$

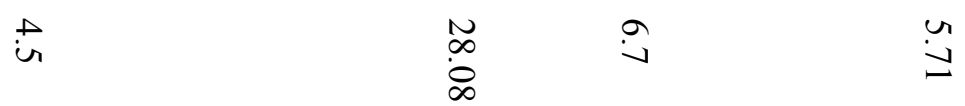

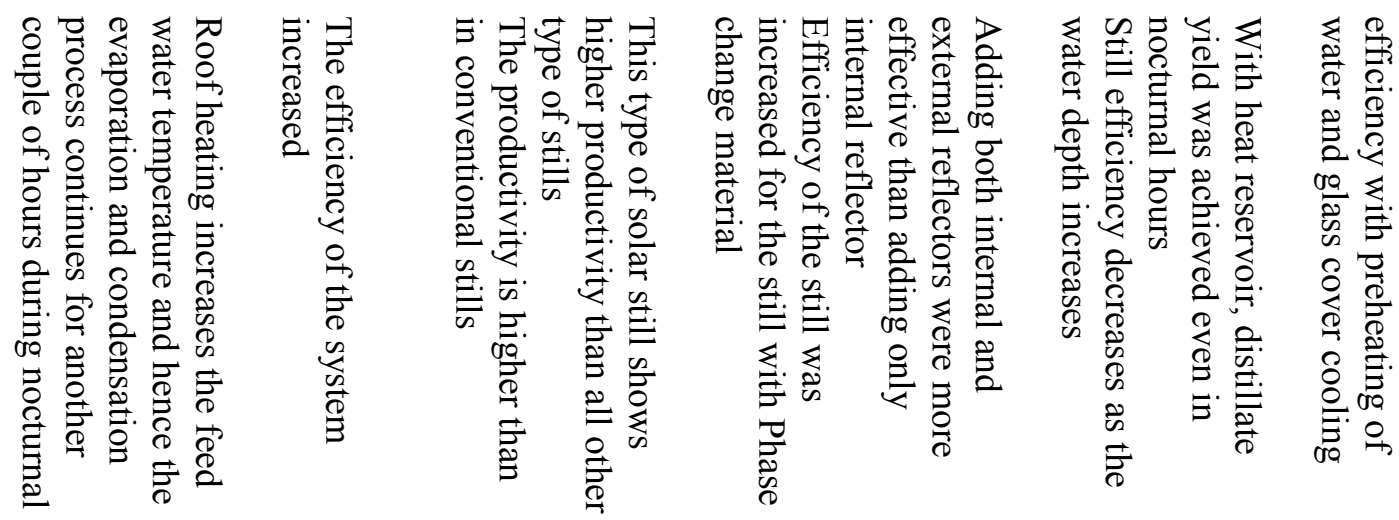




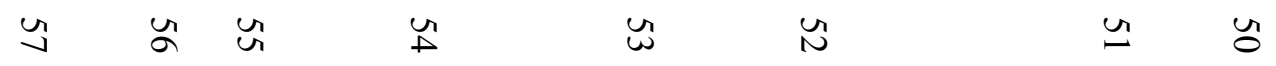

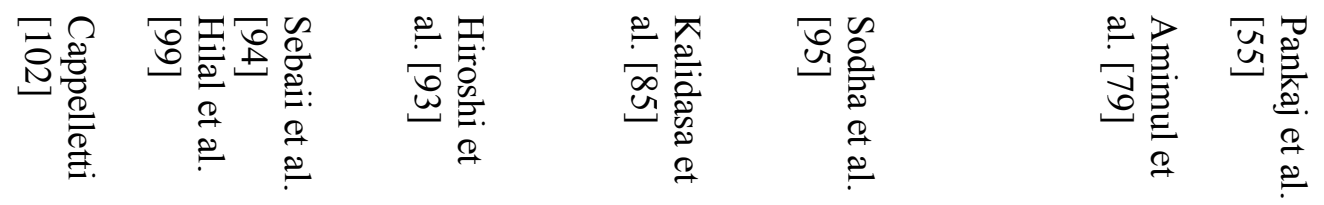

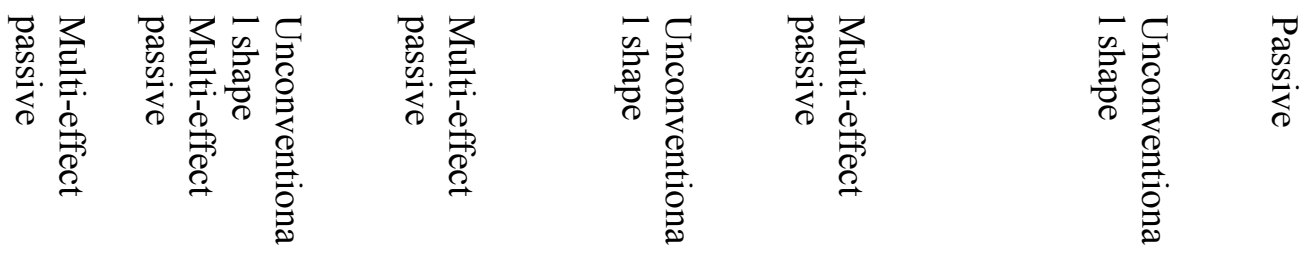

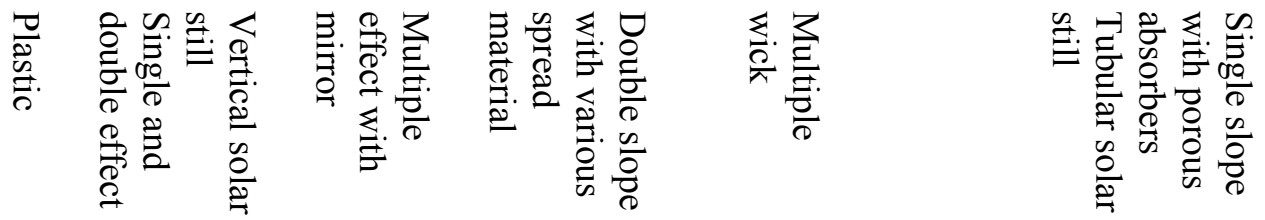

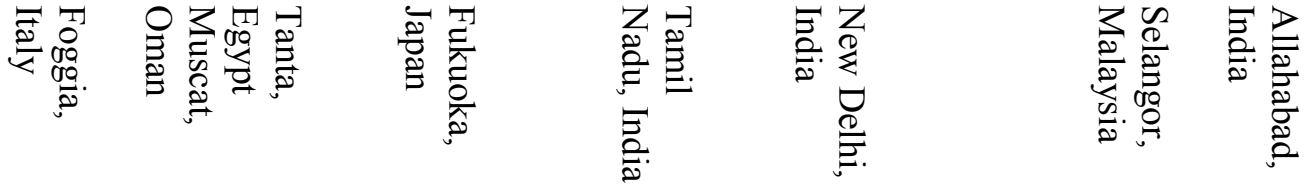

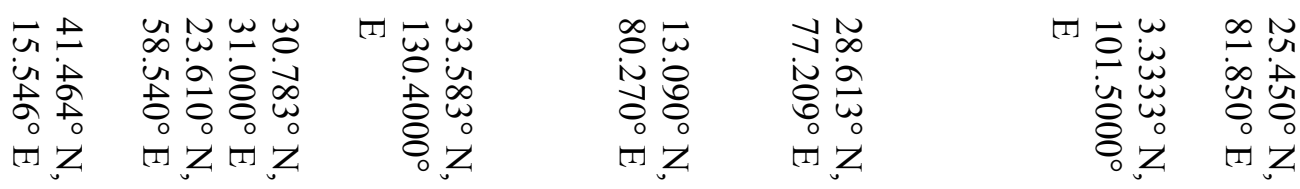

$$
\begin{aligned}
& \stackrel{\omega}{+} \quad \infty
\end{aligned}
$$

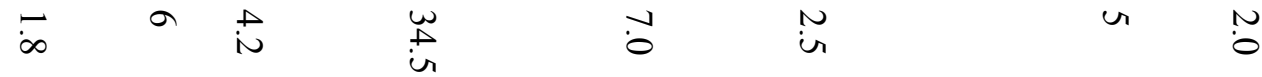

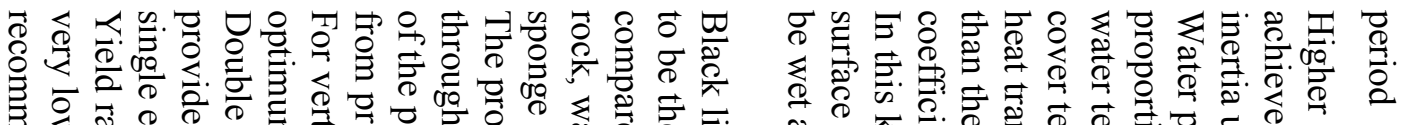

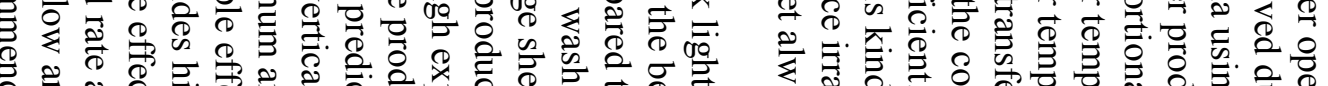

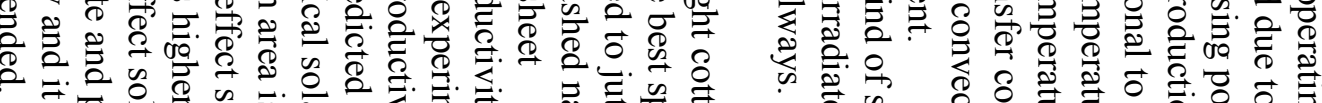

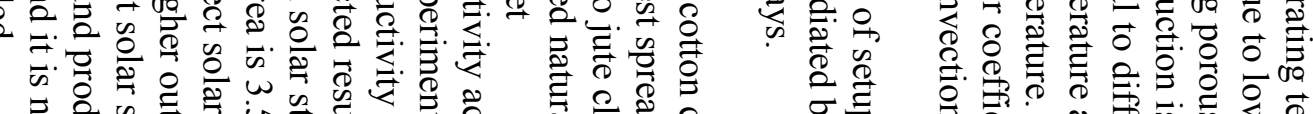

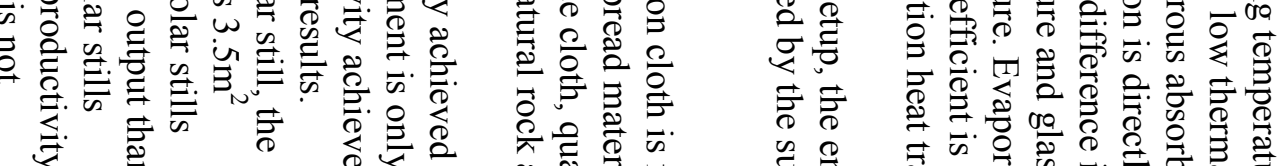

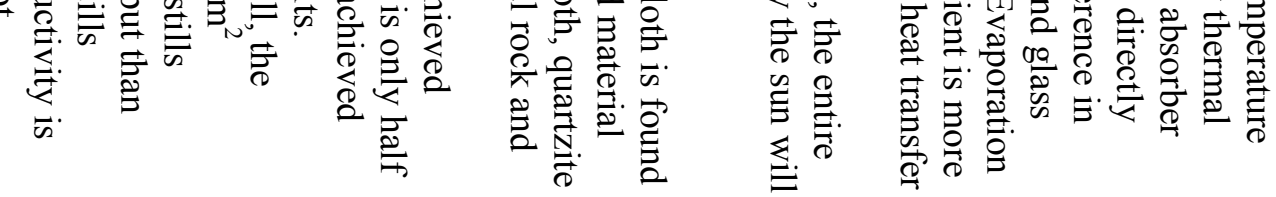




\begin{tabular}{|c|c|c|c|c|}
\hline నิ & $\stackrel{9}{9}$ & 8 & U్ర & $y$ \\
\hline 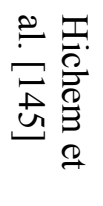 & 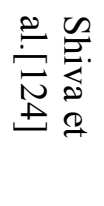 & 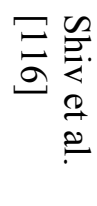 & 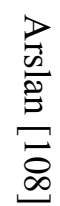 & 马 \\
\hline 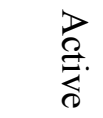 & & 突. & 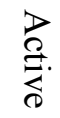 & \\
\hline
\end{tabular}

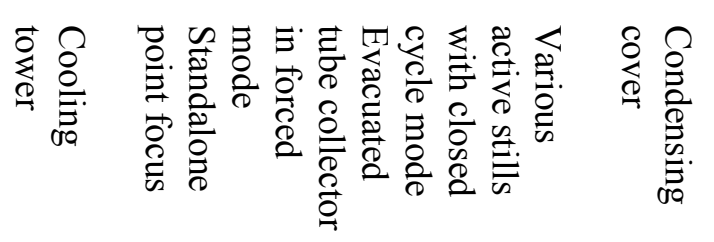

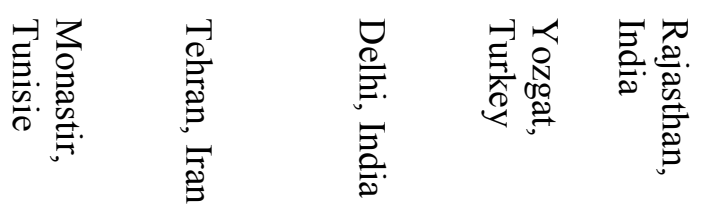

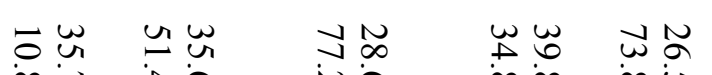

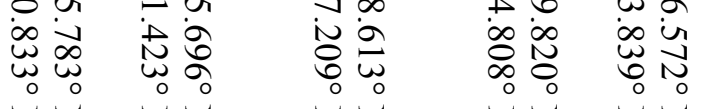

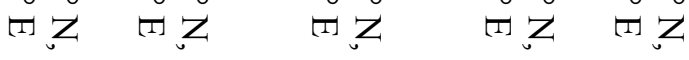

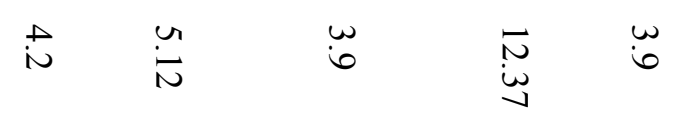

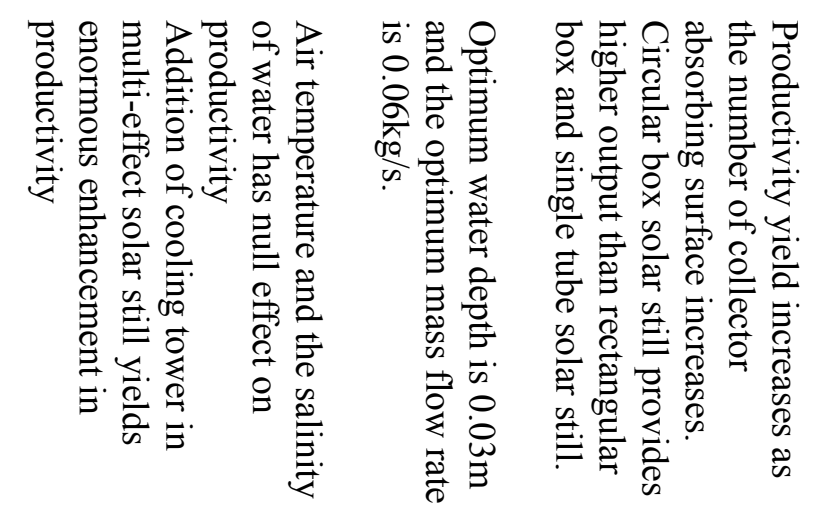


Table.2 Economic analysis of solar stills by various researchers

\begin{tabular}{|c|c|c|c|c|c|c|}
\hline S.no & $\begin{array}{l}\text { Name of the } \\
\text { researcher }\end{array}$ & $\begin{array}{l}\text { Type of the } \\
\text { solar still }\end{array}$ & Location & $\begin{array}{c}\text { Area } \\
\text { of the } \\
\text { still } \\
\left(\mathbf{m}^{2}\right)\end{array}$ & Description & Cost \\
\hline 1 & $\begin{array}{l}\text { Nabil et al. } \\
{[45]}\end{array}$ & $\begin{array}{l}\text { Inclined solar } \\
\text { still with } \\
\text { forced } \\
\text { condensing } \\
\text { techniques }\end{array}$ & Bahrain & 1.0 & $\begin{array}{l}\text { Running cost of the } \\
\text { system (\$) } \\
\text { Yearly cost of water } \\
\text { produced with the } \\
\text { system }(\$)\end{array}$ & 657 \\
\hline & & & & & Capital $\operatorname{cost}(\$)$ & 500 \\
\hline 2 & Ali et al. [71] & $\begin{array}{l}\text { Pyramid } \\
\text { shaped solar } \\
\text { still- Passive } \\
\text { type }\end{array}$ & $\begin{array}{l}\text { Mashhad, } \\
\text { Iran }\end{array}$ & 0.9 & $\begin{array}{l}\text { Annual maintenance } \\
\text { cost }(\$) \\
\text { Cost per liter of fresh } \\
\text { water(\$) }\end{array}$ & $\begin{array}{l}27.62 \\
0.046\end{array}$ \\
\hline 3 & Ali et al. [71] & $\begin{array}{l}\text { Pyramid } \\
\text { shaped solar } \\
\text { still- Active } \\
\text { type }\end{array}$ & $\begin{array}{l}\text { Mashhad, } \\
\text { Iran }\end{array}$ & 0.9 & $\begin{array}{l}\text { Annual maintenance } \\
\text { cost }(\$) \\
\text { Cost per liter of fresh } \\
\text { water(\$) }\end{array}$ & 29.46 \\
\hline 4 & $\begin{array}{l}\text { Arunkumar et } \\
\text { al. [80] }\end{array}$ & $\begin{array}{l}\text { Hemispherical } \\
\text { solar still }\end{array}$ & $\begin{array}{l}\text { Tamil } \\
\text { Nadu, } \\
\text { India }\end{array}$ & 1.21 & $\begin{array}{l}\text { Total capital cost }(\$) \\
\text { Cost per } \mathrm{m}^{2}(\$)\end{array}$ & $\begin{array}{l}0.042 \\
165 \\
233\end{array}$ \\
\hline 5 & $\begin{array}{l}\text { Ismail et al. } \\
\text { [81] }\end{array}$ & $\begin{array}{l}\text { Hemispherical } \\
\text { solar still }\end{array}$ & $\begin{array}{l}\text { Dhahran, } \\
\text { Saudi } \\
\text { Arabia }\end{array}$ & 0.5 & Total capital cost(\$) & 548 \\
\hline 6 & Hilal et al.[99] & $\begin{array}{l}\text { Double effect } \\
\text { solar still }\end{array}$ & $\begin{array}{l}\text { Muscat, } \\
\text { Oman }\end{array}$ & 1.0 & $\begin{array}{l}\text { Capital cost }(\$) \\
\text { Installation } \operatorname{cost}(\$) \\
\text { Total cost }(\$)\end{array}$ & $\begin{array}{l}18975 \\
25502 \\
29328\end{array}$ \\
\hline 7 & Hilal et al.[99] & $\begin{array}{l}\text { Single effect } \\
\text { solar still }\end{array}$ & $\begin{array}{l}\text { Muscat, } \\
\text { Oman }\end{array}$ & 1.0 & $\begin{array}{l}\text { Capital cost }(\$) \\
\text { Installation cost }(\$) \\
\text { Total } \operatorname{cost}(\$)\end{array}$ & $\begin{array}{l}15974 \\
21469 \\
24690\end{array}$ \\
\hline 8 & Shiv et al.[116] & $\begin{array}{l}\text { Solar still with } \\
\text { evacuated tube } \\
\text { collector }\end{array}$ & $\begin{array}{l}\text { Delhi, } \\
\text { India }\end{array}$ & 1.0 & $\begin{array}{l}\text { Cost of water per } \\
\text { liter(\$) } \\
\text { Net uniform annual } \\
\text { cost (Rs) }\end{array}$ & $\begin{array}{l}150 \\
2713.28\end{array}$ \\
\hline 9 & $\begin{array}{l}\text { Gorjian et al. } \\
{[124]}\end{array}$ & $\begin{array}{l}\text { Parabolic solar } \\
\text { still }\end{array}$ & $\begin{array}{l}\text { Tehran, } \\
\text { Iran }\end{array}$ & 1.0 & $\begin{array}{l}\text { Total capital } \\
\text { investment cost }(\$) \\
\text { Cost for producing } \\
\text { fresh water }(\$ / \mathrm{Kg}) \\
\text { Annual energy cost- }\end{array}$ & $\begin{array}{l}1129.85 \\
0.012 \\
6187.40\end{array}$ \\
\hline 10 & $\begin{array}{l}\text { Rajaseenivasan } \\
\text { et al. [205] }\end{array}$ & $\begin{array}{l}\text { Solar still with } \\
\text { circular and }\end{array}$ & $\begin{array}{l}\text { Tamil } \\
\text { Nadu, }\end{array}$ & 1.0 & $\begin{array}{l}\text { electrical(\$/year) } \\
\text { Capital cost of } \\
\text { conventional solar }\end{array}$ & 121.66 \\
\hline
\end{tabular}


square fins India still(\$)

Capital cost for still $\quad 156.67$

with circular fins $(\$)$

Capital cost for still $\quad 154.17$

with square fins(\$)

11 Arunkumar et Tubular solar Tamil

$2.0 \quad$ Total cost of $\quad 263.49$

al. [206] stills (TSS) Nadu,

Compound parabolic

concentrator(CPC)-

$\operatorname{TSS}(\$)$

278.67

tubular stills

Total cost of CPC-

CTSS with water $\quad 319.04$

cooling $(\$)$

Total cost of CPC- $\quad 359.04$

CTSS plus single

slope (\$)

Total cost of CPC-

CTSS plus pyramid(\$)

12 Ayman et al. Solar still with Cairo,

[207] modified still Egypt

$0.25 \quad$ Total capital cost $(\$) \quad 195$

Annual maintenance $\quad 1.31$

$\operatorname{cost}(\$)$

Cost per liter $(\$ /$ liter $) \quad 0.041$

13 Harris Samuel Solar still with Tamil

et al. [208] storage Nadu,

material India

1.1 Total cost for solar still $\quad 0.01$

with spherical bass

heat storage $(\$ /$ liter $)$

Annual cost for solar $\quad 890.25$

still with sponge (Rs)

Initial investment cost 4500

for solar still with

sponge (Rs)

Annual maintenance $\quad 119.40$

cost for solar still with

sponge (Rs)

14 George et al. Solar still with Beirut, 1.005 Annual cost $(\$$

20.96

[209]

rotating

Lebanon

cylinder

15 Sharon et al.

Vertical solar

Tamil

1.0

Total capital $\operatorname{cost}(\$)$

824.15

[210]

still

Nadu,

Distilled water

34.3

India

production $\operatorname{cost}(\$ /$ liter $)$ 